\title{
ESTUDO COMPARATIVO DO PADRÃO DE NORMALIDADE DO PERFIL FACIAL EM JOVENS BRASILEIROS FEODERMAS COM LEUCODERMAS NORTE AMERICANOS
}

Caio Vinicius Martins do Valle

Dissertação apresentada à Faculdade de Odontologia de Bauru, da Universidade de São Paulo, como parte dos requisitos para obtenção do título de Mestre em Odontologia, área de Ortodontia. 


PERFIL FACIAL EM JOVENS BRASILEIROS FEODERMAS COM LEUCODERMAS NORTE AMERICANOS

Caio Vinicius Martins do Valle

Dissertação apresentada à Faculdade de Odontologia de Bauru, da Universidade de São Paulo, como parte dos requisitos para obtenção do título de Mestre em Odontologia, área de Ortodontia.

Orientador: Prof. Dr. Arnaldo Pinzan 


\section{Valle, Caio Vinicius Martins do Valle}

V242e Estudo comparativo do padrão de normalidade do perfil facial em jovens brasileiros feodermas com leucodermas norte americanosl / Caio Vinicius Martins do Valle. -- Bauru, 2006. xix 129 p.: il. ; $30 \mathrm{~cm}$.

Dissertação (Mestrado) -- Faculdade de Odontologia de Bauru. Universidade de São Paulo.

Orientador: Prof. Dr. Arnaldo Pinzan

Autorizo, exclusivamente para fins acadêmicos e científicos, a reprodução total ou parcial desta dissertação/tese, por processos fotocopiadores e outros meios eletrônicos.

Assinatura:

Data:

Comitê de Ética em Pesquisa da FOB: Projeto de pesquisa aprovado em 31 de maio de 2006.

No do Protocolo: 22/2006. 


\section{CAIO VINICIUS MARTINS DO VALLE}

18 de outubro de 1979

Filiação

1999-2002

2005-2007

Associação
Nascimento

Bauru-SP

Accácio Lins do Valle

Tania Gracy Martins do Valle

Curso de Graduação em Odontologia

Universidade Paulista - Bauru-SP

Curso de Pós-graduação em

Ortodontia, em nível de Mestrado,

Faculdade de Odontologia de Bauru USP

Associação Paulista de Cirurgiões-

Dentistas 


\section{DEDICATÓRIA}

Ao Senhor da minha vida, Santo e Eterno Deus,

merecedor de toda a honra e glória, que está à frente

dos meus caminhos, minha paz e fortaleza, sempre fiel,

derramando Sua graça e amor, a tu dedico o mew

louvor pelas infinitas bênçãos. 
Aos meus pais, Accácio e Tania que, com amor, carinho e muita dedicação me incentivaram, com sábias orientações, a enfrentar mais esta etapa, sendo constantemente exemplos de vida.

À minha irmã, Larissa que, com alegria e amizade fiel, me apoiow em todos os momentos.

À minha irmã Karyna, pelo amor e amizade, pelos ensinamentos e ânimo transmitidos, que, por sew exemplo de competência e dedicação ao ensino, inspirow-me a buscar conhecimento do mundo cientifico e formação ortodôntica.

Ao Mauro, pela amizade e compreensão, nos momentos dificeis, desta etapa da minha formação.

Dedico este trabatho. 


\section{AGRADECIMENTOS ESPECIAIS}

A toda minha familia que sempre me dedicou amor e atenção. Aos mens avós Accácio, Nútda e João que nunca se esqueceram de mim em suas oraçöes.

À Ana Aída pela atenção e carinho a mim dedicados durante toda a minha vida.

A todos os mens amigos e irmaios em Cristo, que me sustentaram em oração durante a execução deste trabalho. 
Mew Agradecimento Especial ao mew orientadore educador,

\section{Professor Doutor Arnaldo Pinzan}

Minha eterna gratidão pelo apoio, dedicação e orientação, pelo exemplo como Mestre demonstrando humanidade e atenção, para mim motivos de estimulo durante esses anos de convivência. 
Aos professores,

Doutor Eduardo Sant Ana

Agradeço a atenção, disposição e colaboração que possibilitaram a execução deste trabalho. Obrigado pelo incentivo e pela amizade, mostrando-se sempre pronto a me ajudar.

Doutor José Roberto Pereira Lauris

Pela sua inestimável colaboração na reatização da análise estatistica. 


\section{AGRADECIMENTOS}

Ao Professor Doutor Luiz Fernando Pegoraro, diretor desta Faculdade, pelo incentivo transmitido.

A Professora Doutora Maria Aparecida de Andrade Moreira Machado, Presidente da Comissão de Pós-Graduação da FOB-USP, pela compreensão e amizade.

Aos Professores Doutores da Disciplina de Ortodontia da Faculdade de Odontologia de Bauru,

Prof. Dr. DÉCIO RODRIGUES MARTINS,

Prof. Dr. RENATO RODRIGUES DE ALMEIDA,

Prof. Dr. JOSÉ FERNANDO CASTANHA HENRIQUES,

Prof. Dr. MARCOS ROBERTO DE FREITAS,

Prof. Dr. GUILFERME DOS REIS PEREIRA JANSON,

pelos ensinamentos e experiências transmitidos, pelo incentivo e apoio constantes e pela confiança a mim dispensada. 
Aos amigos do Curso de Mestrado, por todos os momentos pelos quais passamos juntos, pela amizade e respeito durante esses anos. Vocês foram fundamentais para a conchusão deste curso. 
Aos funcionários da Discíplina de Ortodontia, por toda a amizade e atenção durante o nosso convívio.

Aos funcionários da Pós-Graduação, pela ajuda e dedicação com que sempre me atenderam.

Aos funcionários da Biblioteca, pela atençãoe amizade e pela prontidão ao me ajudarem.

Aor funcionários desta Faculdade, pela dedicação a mim transmitidos.

Aos pacientes da Pós-Graduação, pela colaboração para minha formação. 


\section{SUMÁRIO}

LISTA DE TABELAS ................................................................................. xiv

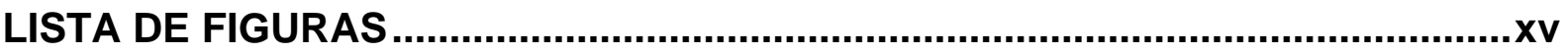

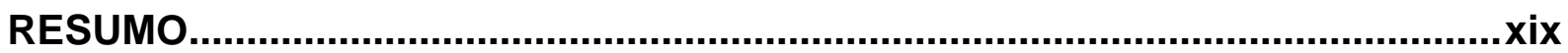

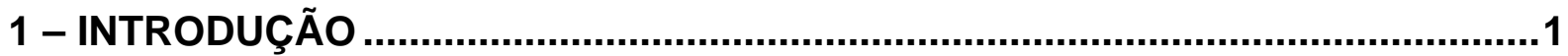

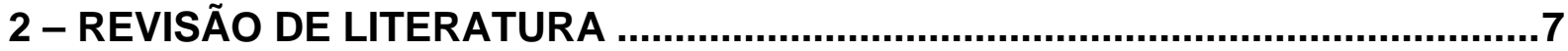

2.1 - Conceitos de Normalidade da Face ......................................................

2.2 - Análise do perfil facial ........................................................................ 16

2.3 - Relação entre Tecido Tegumentar e Tecido Esquelético ..............................26

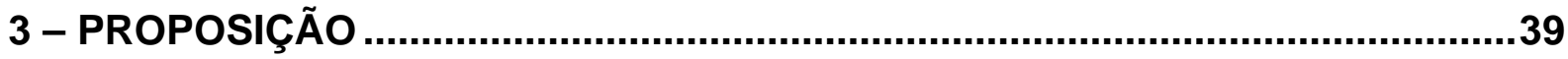

4 - MATERIAL E MÉTODOS …......................................................................

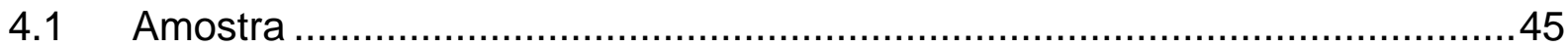

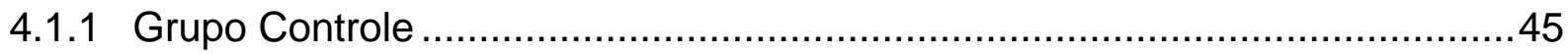

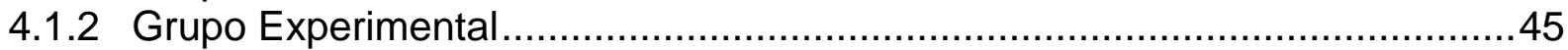

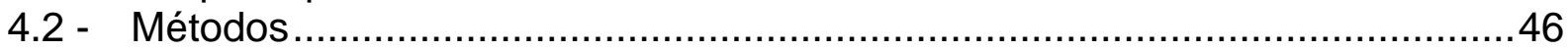

4.2.1 - A obtenção das Radiografias Cefalométricas ............................................46

4.2.2 - A Elaboração dos Cefalogramas ........................................................... 49

4.2.3 - Delimetação do desenho Anatômico ……………………….....................53

4.2.4 - Demarcação dos Pontos Cefalométricos....................................................55

4.2.5 - Determinação da Linha Vertical Verdadeira ..............................................61

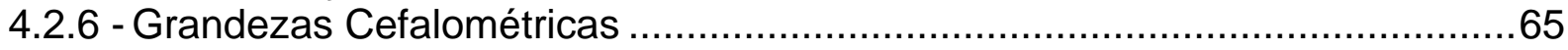

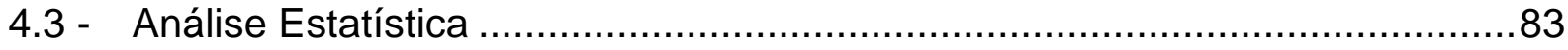

5 - RESULTADOS

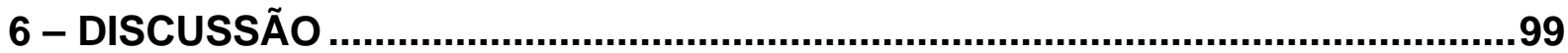

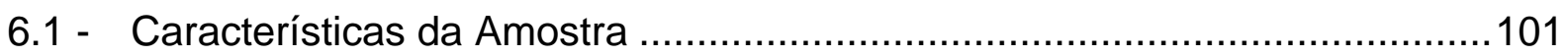

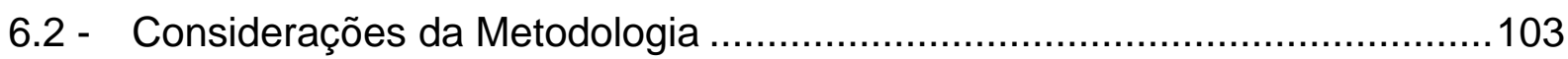

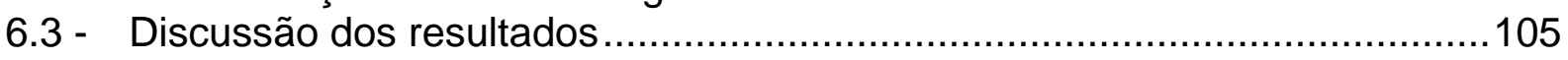

6.3.1 - Comparação entre os sexos feminino e masculino …................................105

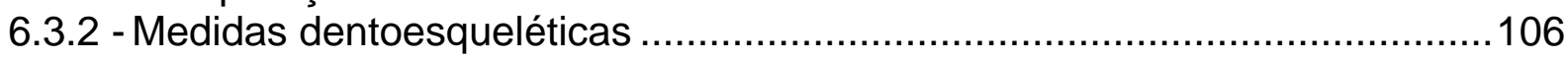

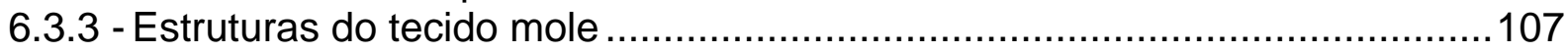

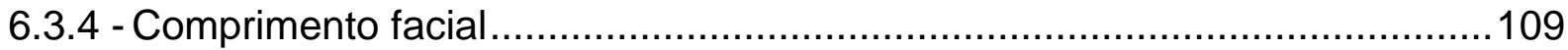



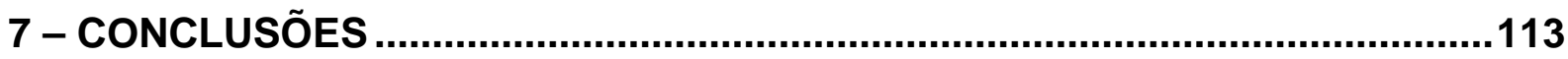

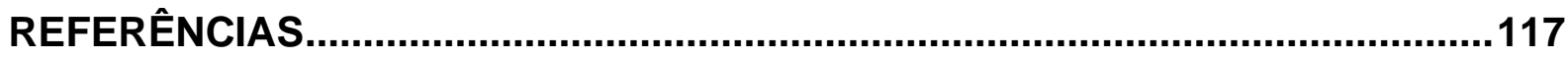

ABSTRACT

APÊNDICE 


\section{LISTA DE TABELAS}

TABELA 1 - Erro do método da análise cefalométrica do tecido mole utilizando o software Dolphin

TABELA 2 - Comparação das medidas dentoesqueléticas entre os sexos feminino e masculino dos feodermas brasileiros 91

TABELA 3 - Comparação das medidas dos tecidos moles entre os sexos feminino e masculino dos feodermas brasileiros 91

TABELA 4 - Comparação das medidas do comprimento facial entre os sexos feminino e masculino dos feodermas brasileiros

TABELA 5 - Comparação das medidas de projeção em relação à LVV entre os sexos feminino e masculino dos feodermas brasileiros.

TABELA 6 - Comparação das medidas dentoesqueléticas dos feodermas brasileiros da análise cefalométrica do tecido mole com o padrão americano para o sexo feminino.

TABELA 7 - Comparação das medidas dentoesqueléticas dos feodermas brasileiros da análise cefalométrica do tecido mole com o padrão americano para o sexo masculino

TABELA 8 - Comparação das medidas dos tecidos moles dos feodermas brasileiros da análise cefalométrica do tecido mole com o padrão americano para o sexo feminino.

TABELA 9 - Comparação das medidas dos tecidos moles dos feodermas brasileiros da análise cefalométrica do tecido mole com o padrão americano para o sexo masculino

TABELA 10 - Comparação das medidas do comprimento facial dos feodermas brasileiros da análise cefalométrica do tecido mole com o padrão americano para o sexo feminino

TABELA 11 - Comparação das medidas do comprimento facial dos feodermas brasileiros da análise cefalométrica do tecido mole com o padrão americano para o sexo masculino.

TABELA 12 - Comparação das medidas da projeção à LVV dos feodermas brasileiros da análise cefalométrica do tecido mole com o padrão americano para o sexo feminino.

TABELA 13 - Comparação das medidas da projeção à LVV dos feodermas brasileiros da análise cefalométrica do tecido mole com o padrão americano para o sexo masculino..... 


\section{LISTA DE FIGURAS}

Figura 1 - Marcadores metálicos posicionados para a realização da telerradiografia. De cima para baixo os marcadores estão posicionados nos pontos cefalométricos da rima orbitária, ponto da maçã, ponto da região subpupilar, base nasal e ponto da linha mento-pescoço.

Figura 2 - Visualização dos marcadores metálicos na telerradiografia. De cima para baixo os marcadores posicionados nos pontos cefalométricos da rima orbitária, ponto da maçã, ponto da região subpupilar, base nasal e ponto da linha mento-pescoço.

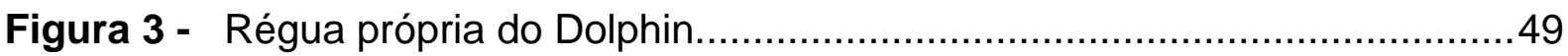

Figura 4 - Interface do software Dolphin Imaging, versão $9.0 \ldots \ldots \ldots \ldots \ldots \ldots \ldots \ldots \ldots . \ldots \ldots 1$

Figura 5 - Interface do software Dolphin Imaging, versão 9.0 mostrando o cefalograma.

Figura 6 - Delimitação do desenho anatômico. 55

Figura 7 - Pontos de referência do traçado cefalométrico 61

Figura 8 - Linha Vertical Verdadeira 63

Figura 9 - Altura posterior da maxila (ângulo formado pelo plano oclusal da maxila e a Linha Vertical Verdadeira).

Figura 10 - Ângulo formado pelo incisivo superior e o plano oclusal da maxila. 67

Figura 11 - Ângulo formado pelo incisivo inferior e o plano oclusal da mandíbula. ..69

Figura 12 - Overjet e Overbite.

Figura 13 - Espessura do lábio superior, inferior, pogônio e mento. 73

Figura 14 - Ângulo Nasolabial 75

Figura 15 - Ângulo do Lábio Superior. 75

Figura 16 - Comprimento facial. 79

Figura 17 - Projeção dos pontos cefalométricos do tecido mole em relação à Linha Vertical Verdadeira. 

RESUMO 



\section{RESUMO}

O objetivo deste trabalho foi aferir as medidas do perfil facial de brasileiros feodermas (grupo experimental) comparando-os as medidas padronizadas por ARNETT para leucodermas norte-americanos (grupo controle). A amostra do grupo experimental constituiu-se de 39 telerradiografias, em norma lateral, sendo 20 do sexo feminino e 19 do sexo masculino, com idades entre 18 e 35 anos, apresentando "oclusão normal" e nunca submetidos a tratamento ortodôntico. As radiografias foram digitalizadas e inseridas no software Dolphin 9.0, para a realização das medidas cefalométricas da Análise Cefalomética do Tecido Mole proposta por ARNETT. Os valores obtidos foram comparados pelo teste $t$ paramétrico não pareado com $p<0,05$. Após a análise dos resultados verificou-se que os feodermas de ambos os sexos apresentaram o incisivos superiores $\mathrm{e}$ inferiores mais vestibularizados, maior espessura do lábio superior e do mento, o ângulo nasolabial mais fechado, menor comprimento do lábio inferior, maior projeção da maxila, maior retrusão do queixo e perfil mais convexo. Apenas os feodermas brasileiros do sexo feminino apresentaram maior espessura do queixo e a altura facial semelhante aos leucodermas norte-americano do mesmo sexo. Concluiu-se que o perfil facial dos feodermas brasileiros é diferente dos leucodermas norteamericanos e necessitam de planejamentos diferentes. 

1 - INTRODUÇÃO 



\section{1 - INTRODUÇÃO}

"A beleza pode ser definida como um estado de harmonia e equilíbrio das emoções faciais, estabelecidas pelas estruturas esqueléticas, pelos dentes e tecidos moles"34.

Assim como uma das preocupações do ser humano tem sido a busca pelo belo, cuja compreensão do conceito é inato e amplamente subjetivo, no que se refere à ortodontia esse conceito remete ao desejo de uma face esteticamente harmoniosa, uma das metas do tratamento ortodôntico.

As opiniões do que é beleza facial diferem de acordo com alguns fatores como cultura, padrão socioeconômico e etnia, constitui uma grande dificuldade no estabelecimento de uma regra ou norma para avaliação facial dos pacientes. Quanto mais se observa um padrão facial, mais ele é considerado como ideal, fato este que justifica pessoas a comungarem um senso comum da apreciação da beleza facial, apesar de todas as diferenças como nacionalidade, idade e sexo. O senso estético é o produto de diversos fatores culturais que conduzem à unificação das preferências individuais, os quais se tornam principais documentos de divulgação de beleza, reforçando determinados padrões estéticos.

O significado de "beleza facial" segundo ARNETT; McLAUGHLIN (2004) ${ }^{11}$ é uma característica que depende do olho humano, tornando extremamente difícil se definir componentes de beleza, pois esta objetividade é dificultada por preferências individuais, culturais e pela crença de que a beleza se apresenta de formas diferentes e com características distintas. Aos olhos do ser humano isso não é tão relevante do ponto de vista de objetividade, enquanto que, para cirurgiões-dentistas, trata-se de um conceito altamente relevante.

PROFFIT; WHITE; SAVER ${ }^{83}$ definem deformidades dentofaciais como desproporções faciais e dentárias extensas, as quais podem afetar significantemente a qualidade de vida do ser humano, requerendo atuação conjunta de especialidades 
como ortodontia e cirurgia ortognática. Este fato nos remete a uma pequena porcentagem da população prejudicada, funcional ou socialmente, por componentes faciais ou dentários que fogem do contexto de normalidade, como por exemplo, pacientes com face longa e mordida aberta, que muitas vezes são vistos com algum grau de anormalidade. Esse tipo de alteração pode muitas vezes levar o paciente a uma grande dificuldade de interação social, deixando-o à parte da sociedade.

Se por um lado a estética facial de um paciente pode ser melhorada e alterada pelos cirurgiões-dentistas, um diagnóstico errado pode levar a uma vida inteira de insatisfações emocionais e físicas. Uma coletânea de informações é necessária na elaboração de um plano de tratamento correto, baseando-se em dados obtidos tais como: (1) motivação do paciente pelo tratamento proposto; (2) no exame clínico facial e intrabucal executado e (3) na análise da documentação inicial como modelos e radiografias.

As alterações na morfologia óssea e posicionamento dentário em uma análise da telerradiografia em norma lateral permitem ao cirurgião-dentista um diagnóstico mais preciso das deformidades das estruturas esqueléticas e posicionamento dentário. Mensurações esqueléticas da face e crânio permitem a localização dessas deformidades e a quantificação das mudanças a serem realizadas. A avaliação cefalométrica torna-se então, uma ferramenta indispensável para o plano de tratamento e o monitoramento dos procedimentos ortodônticocirúrgicos.

O tratamento de pacientes com deformidades faciais busca uma eficiência funcional, harmonia estética e estabilidade de resultados e, devido a isso, a estética facial passou a ter íntima relação com a ortodontia ${ }^{105}$.

A ortodontia tem vivenciado uma mudança de valores, passando recentemente a dar um enfoque maior do perfil tegumentar inferior. A opinião e a percepção do paciente passam a contribuir de maneira significativa nessa mudança de valores, pois a aparência estética é motivo primordial para pacientes buscarem um tratamento integrado da ortodontia e cirurgia ortognática.

No tratamento ortodôntico, quando identificado um comportamento facial, a sua explicação é muitas vezes definida pelo mau posicionamento das bases 
ósseas e incisivos. Na cirurgia, esse diagnóstico ocorre também com grande freqüência e isso acontece por empregarem análise cefalométricas mais tradicionais.

A utilização da radiografia cefalométrica para avaliar o crescimento e desenvolvimento dos tecidos esqueléticos e dentários motivou os profissionais a buscarem um equilíbrio e harmonia dos mesmos. NANDA ${ }^{72}$, em 1995, afirma que "a introdução da radiografia no diagnóstico ortodôntico desviou inadvertidamente os especialistas da área dos tecidos moles para estruturas esqueléticas".

Em 1999, ARNETT et al. ${ }^{10}$, propuseram um novo tipo de análise cefalométrica dos tecidos, baseada em uma linha vertical. Linha vertical verdadeira ou TRUE VERTICAL LINE é uma reta que, localizada à frente do rosto do paciente, passa pelo ponto subnasal e por um segundo ponto localizado a um centímetro anteriormente à glabela. Utilizando essa linha como referencial, conseguiu quantificar numericamente as grandezas de todo perfil facial.

Os estudos em diferentes populações mostraram que padrões de normalidade medidas do perfil facial diferem entre raças $^{18,103}$, exigindo estudos individualizados para cada população ${ }^{60,81}$. 

2 - REVISÃO DE
LITERATURA 



\section{2 - REVISÃO DE LITERATURA}

Com a finalidade de facilitar o entendimento da literatura relacionada com o presente trabalho, os artigos da revisão de literatura foram agrupados em:

1) Conceitos de normalidade da face;

2) Perfil Mole;

3) Relação entre tecido tegumentar e tecido esquelético.

\section{1 - Conceitos de Normalidade da Face}

A definição de um padrão estético é indispensável para se iniciar e concluir um tratamento. No entanto, a literatura apresenta interpretações variadas quanto ao padrão de normalidade, principalmente quando se consideram as diferentes populações e etnias estudadas.

ANGLE $^{5}$ (1907), o precursor da ortodontia moderna, afirmou que a arte da face humana está relacionada com o estudo da ortodontia. Usando os termos balanço, harmonia, proporção, beleza e feiúra escreveu sobre a importância da estética facial. Afirmou ainda que, embora o conceito do perfil ideal estivesse baseado no perfil grego clássico de Apolo Belvedere, seria impossível aplicá-lo à população americana, pois o modelo de vida americano sofreu ao longo do tempo a influência de alguns fatores que propiciam modificações nos padrões de beleza. Destacou, dentre os principais fatores, as condições sócio-culturais e climáticas, os hábitos de comportamento, ocupação e atividade mental da população americana.

WUERPEL ${ }^{111}$, em 1937, ressaltou a influência da arte grega e, em especial, da estátua de Apolo nos conceitos da estética facial ao longo dos séculos. Ao relacionar o conceito da face ideal à ortodontia, vislumbrou a impossibilidade de 
adaptação de um único modelo a todas as faces, sugerindo o ideal individual. Para tanto, os ortodontistas teriam que considerar a saúde e o conforto dos pacientes e advertiu os profissionais para que não modificassem a face dos pacientes quando não pudessem manter ou proporcionar maior equilíbrio das características faciais.

TWEED ${ }^{106}$, em 1954, apresentou um conceito do que para ele era "normal". Acreditava que o "equilíbrio e harmonia das proporções consideradas, pela maioria de nós, como mais agradáveis na face humana" seria a definição de "normal", afirmando ainda que, devido à grande variação de mistura de grupos étnicos da raça branca, é essencial que ortodontistas tenham um padrão definido para orientá-los em seus tratamentos, devendo sempre estar em harmonia com sua idéia de "normal".

Em 1957, RIEDEL ${ }^{90}$ considerou, em seu trabalho, que existem quatro fontes primárias das quais aceitamos ou obtemos nossos ideais estéticos: 1) 0 idealismo estético derivado de desenhos, pintura e esculturas antigas; 2) a influência de homens, tais como Tweed, que desenvolveram conceitos de estética baseados na aceitação de agradável ou satisfatório de um rosto no qual a dentadura é estável, com os incisivos em posição ereta, não apinhada; 3) normas cefalométricas angulares e lineares sobre telerradiografias laterais que se baseiam em pessoas de excelente oclusão; 4) perfis admirados e desejados como os vistos em astros de cinema, modelos e rainhas de beleza.

Baseados em investigações na área da psicologia e sociologia, PECK; $\mathrm{PECK}^{77}$ foram os primeiros a indagar sobre a relevância da estética facial para a ortodontia, procurando demonstrar a semelhança do gosto popular junto à preferência estética. Estudaram padrões faciais de 52 adultos jovens considerados com estéticas agradáveis. A amostra constituiu de modelos profissionais, vencedores de concurso de beleza e artistas, conhecidos por notável atratividade facial. Foram feitas radiografias cefalométricas, analisadas de acordo com Steiner, Downs e Margolis, indicando que o público em geral apresentou admiração maior pelo padrão dentofacial mais protrusivo e mais cheio. Observaram também que a estética variava de uma cultura para outra, sofrendo influência dos meios de comunicação, que sempre mostravam faces esteriotipadas. Afirmaram que seria muito difícil que ortodontistas fugissem desses padrões onipresentes. 
Em 1978, BURSTONE ${ }^{23}$ alertou sobre o fato de os pacientes se amoldarem a um padrão cefalométrico e, afirmou que o clínico deve saber primeiramente se o desejo do paciente é apresentar as características faciais da população caucasiana. Salientou também que avaliação cefalométrica foi somente um passo no diagnóstico e plano de tratamento.

Dois anos depois, complementou: “Os padrões representam nada mais do que médias de uma população caucasiana heterogênea que não foi subdividida por sexo, ou fundamentos étnicos. Eles reproduzem uma face americana média do adulto jovem. O clínico não deve se esquecer de que cada paciente ou membro familiar pode ter um conceito diferente de estética facial, baseado em fundamentos étnicos ou raciais, familiares ou preferências pessoais" $"$.

Devido às variáveis encontradas entre os diferentes grupos étnicos, FLYNN; AMBROGIO; ZEICHNER ${ }^{41}$ (1989) estabeleceram valores cefalométricos para negros norte-americanos adultos, objetivando valores normativos adaptados a essa etnia segundo a "Análise Cefalométrica para Cirurgia Ortognática". Os critérios de seleção foram oclusão normal e ausência de assimetria facial. Os resultados obtidos permitiram informações proveitosas para o diagnóstico e plano de tratamento cirúrgico, destacando que a estética facial não foi o motivo da pesquisa.

Analisando as grandes divergências quanto aos padrões e normas para a face humana, CZARNECKI; NANDA; CURRIER ${ }^{31}$ (1993) realizaram um estudo no Departamento de Ortodontia da Universidade de Oklahoma, com o objetivo de determinar um perfil facial ideal. Desenvolveram uma série de perfis faciais, que foram avaliados por 575 profissionais. Variaram o tamanho dos lábios, nariz, mento, ângulo de convexidade facial e o ângulo facial e buscavam as combinações mais aceitáveis, assim como as menos desejáveis. Com base nos dados da literatura sobre espessura tegumentar e sua relação com o esqueleto subjacente, construíram um perfil facial esquelético e dos tecidos moles. Verificaram que a posição da protrusão e retrusão labial dependeu das posições do mento e do nariz, sendo permitida três vezes mais protrusão labial com o mento grande do que com o nariz grande. Este achado foi significante porque tem maior impacto sobre os planos de tratamento. Com nariz e mento relativamente maiores, a dentição mais protruída e lábios mais cheios são mais aceitáveis para harmonizar a face. Afirmaram ainda 
que, em qualquer tipo de filosofia de tratamento, a harmonia das características faciais e estéticas é primordial, devendo o clínico ser capaz de diferenciar o "normal" (aceitável) do "anormal" (inaceitável).

Testando a hipótese anterior, PERRET; MAY; YOSHIKAWA ${ }^{78}$, em 1994, utilizaram composições de faces da raça branca e amarela, encontrando coincidências transculturais no julgamento da atratividade da face feminina, comprovando que a média não é a única determinante, rejeitando o conceito de que "atratividade é uma média". Mostraram em seus resultados que faces muito atrativas são sistematicamente distintas da média.

SCOTT; JOHNSTON Jr ${ }^{98}$, em 1999, analisaram a estética no perfil facial das terapias com e sem extrações de pré-molares em pacientes afro-americanos. A decisão de extrair ou não os pré-molares baseou-se em três variáveis: 1) discrepância dentária, 2) sobressaliência e 3) protrusão do perfil, concluindo que o perfil facial melhorou com a terapia de extrações. Afirmaram que como a protrusão do perfil é uma queixa comum para grande parte desses pacientes, e como as extrações podem oferecer uma redução modesta da protrusão, pode-se esperar que esta opção de tratamento torne-se potencialmente benéfica.

Diante das diferentes técnicas preferidas pelos profissionais, influências culturais, nível educacional e subjetividade, devem-se aceitar as mudanças que esses conceitos apresentaram com passar do tempo. Historicamente, a arte mostra claramente a variabilidade do conceito de beleza através da época analisada, especialmente quando se refere à face. NGUYEN; TURLEY (1998) ${ }^{74}$ e AUGER; TURLEY (1999) ${ }^{12}$ mostraram a mudança pela qual a beleza facial mudou e foi apresentada em revistas de moda e beleza no EUA, durante o século $X X$, resultados estes significantes na região dos lábios. Verificaram características associadas à juventude: maior protrusão, mais definição em seu contorno e exposição do lábio. Esses resultados mostraram que o público americano valorizou muito mais um perfil mais "cheio" e que exportou essa preferência a outros países ocidentais.

HENRIQUES et al. ${ }^{48}$, em 1999, também relataram a necessidade de se utilizar um padrão cefalométrico específico para os brasileiros descendentes de xantodermas japoneses, após a realização de um estudo envolvendo 41 jovens com 
média de idade de 15,71 anos, avaliados por meio de telerradiografias cefalométricas em norma lateral, para determinar valores médios da avaliação "Wits". Os resultados demonstraram também ausência de dimorfismo entre o sexo masculino e feminino quanto a esta medida. Comparando esse estudo com o de So e King ${ }^{99}$ sobre a medida de "Wits" para xantodermas chineses, concluíram que, apesar de os chineses, japoneses e seus descendentes pertencerem ao mesmo grupo racial (xantoderma), havia diferenças entre os valores cefalométricos obtidos, provavelmente por pertencerem a grupos étnicos específicos. Em vista disso, havia necessidade de se estabelecerem valores médios para um melhor diagnóstico e planejamento ortodôntico em indivíduos de diferentes grupos raciais e éticos.

Visando a um método de avaliação do perfil facial dos japoneses adultos normais, ALCALDE et al. ${ }^{1}$ (2000) selecionaram algumas medidas cefalométricas. Para estabelecer os valores médios normativos, estudaram as radiografias cefalométricas de 211 japoneses adultos normais e compararam as medidas dos tecidos moles com as de uma amostra de japoneses com estética agradável e também com outra amostra de adultos leucodermas. Diferenças significantes foram encontradas no grupo de japoneses quando comparado com o dos leucodermas. Por outro lado, os valores médios referentes aos contornos tegumentares do grupo de japoneses pré-selecionados pela estética facial revelaram-se similares aos valores obtidos para os leucodermas, com exceção do ângulo nasolabial e das proeminências labial e nasal. As normas cefalométricas referentes aos tecidos moles eram, portanto, específicas para os grupos étinicos, mas os valores médios representavam apenas um auxílio para o diagnóstico e planejamento do tratamento ortodôntico e da cirurgia ortognática.

REIS; CAPELOZZA FILHO; MANDETTA (2002) ${ }^{84}$, estudando características dentárias em indivíduos com perfil facial normal, referiram-se ao termo "normal" como o que se repete na maioria da população. A amostra foi constituída na maioria por população adulta, demonstrando que 7\% apresentou oclusão normal e 93 \% más oclusões, sendo 48\% Classe I, 42\% Classe II e 3 \% Classe III. Destacaram como critério de seleção um selamento labial passivo. A intenção foi selecionar uma amostra de indivíduos "normais" do ponto de vista da análise facial e o selamento labial passivo foi considerado normalidade funcional do perfil. Os autores concluíram que, apesar de poucos artigos científicos na literatura, 
o uso da terminologia "normal" refere-se ao que se repete sempre na maioria da população e ainda que ousada, apresenta-se bastante apropriada ao uso.

Em 2005, JOHNSTON et al. ${ }^{56}$ realizaram um estudo com a finalidade de verificar a influência da proeminência mandibular sobre a atratividade facial. Basearam o estudo na alteração apenas da posição sagital da mandíbula, com a posição da maxila e a dimensão vertical inalterada. Após o desenho do cefalograma de um paciente com o valor do ângulo SNB igual a $78^{\circ}$, foi desenhada a silhueta deste perfil e, a partir desta, oito silhuetas foram obtidas variando-se o valor do ângulo SNB em $2.5^{\circ}$, de $68^{\circ}$ a $88^{\circ}$. Cento e doze avaliadores leigos foram escolhidos para conduzir a avaliação. Embora a maioria dos avaliadores fossem mulheres $(72,5 \%)$, os resultados revelaram que o sexo dos mesmos não afetou a avaliação. 0 perfil selecionado como o mais atraente foi o da imagem que representou o ângulo SNB igual a $78^{\circ}$ e o valor de SNA igual a $81^{\circ}$. Os perfis classificados como menos atraentes foram vistos nos intervalos entre o ângulo SNB de $73^{\circ}$ e $70,5^{\circ}$ (retrusão do mento mole) e $83^{\circ}$ e $85^{\circ}$ (protrusão do mento mole). Os resultados indicam que, para os leigos, existe ampla margem de aceitação da discrepância esquelética, enquanto que os ortodontistas aceitam variação menor, correspondente a um desvio-padrão.

TODD et al. ${ }^{104}$ (2005) investigaram se a preferência das relações faciais por profissionais da saúde e leigos é a Classe I e apuraram se a vista em duas (2D) ou em três dimensões (3D) das imagens pode afetar a classificação da atratividade facial. Selecionaram quatro indivíduos, dois homens e duas mulheres, dos quais foram obtidas imagens da face por meio de um scanner. As imagens foram modificadas e deram origem a cinco faces com padrões distintos: Classe I, Classe II leve e moderada e Classe III leve e moderada. As imagens em 2D e 3D foram submetidas à avaliação por três grupos de examinadores (ortodontistas, cirurgiões bucomaxilofaciais e leigos). Os resultados indicaram que, nas imagens em 2D, os ortodontistas e cirurgiões bucomaxilofaciais preferiram a imagem da Classe I, quando comparados com o público, em geral, mas salientaram que essa diferença não foi observada em todas as faces. Nas imagens em 3D, os profissionais da saúde escolheram imagens mais variadas, quando comparados ao público em geral. O sexo dos avaliadores não foi significativo quando foi avaliada a preferência da perfil facial nas imagens de Classe I, em ambos os formatos, 2D e 3D. Observaram grande variação nos resultados, o que possibilitou a afirmação de que as diferenças 
entre as imagens em 2D e 3D não foram evidentes.

MAPLE et al. ${ }^{63}$ (2005) realizaram uma pesquisa com o objetivo de avaliar a percepção da atratividade facial realizada por profissionais e leigos. Utilizaram fotografias e telerradiografias de três homens e três mulheres, sendo que as fotografias originais foram alteradas com incrementos de $4 \mathrm{~mm}$, produzindo diferentes combinações na posição horizontal da mandíbula e na altura facial anterior inferior. Participaram da pesquisa cem avaliadores, cinqüenta ortodontistas, vinte e cinco cirurgiões bucomaxilofaciais e vinte e cinco leigos, os quais foram orientados para preencher uma ficha contendo uma escala visual, por constituir-se em um método simples e eficiente de avaliação. Concluíram que houve concordância entre os ortodontistas, cirurgiões bucomaxilofaciais e leigos nas suas percepções da atratividade facial, com a preferência pelo perfil equilibrado. As interações das dimensões ântero-posterior e vertical e a magnitude dessas mudanças influenciaram a percepção da atratividade facial, resultado na classificação de perfis com extrema convexidade e concavidade como os menos atraentes.

SANT'ANA $^{94}$ procurou determinar um padrão de normalidade facial de brasileiros leucodermas por um estudo entre os achados padronizado encontrados por ARNETT et al. ${ }^{10}$, utilizaram o software Dolphin 9.0. A amostra constituiu-se de 31 pacientes adultos com oclusão Classe I de Angle e harmonia facial. Concluiu que os números na análise do perfil mole dos brasileiros são diferentes dos encontrados nos norte-americanos, exceto em quatro pontos para o sexo masculino e outros quatro, para o sexo feminino. Os brasileiros apresentam uma face menos protruída, um perfil mais convexo e menor proeminência do queixo.

SCAVONE et al. ${ }^{96}$ realizaram um estudo para determinar o perfil facial de japoneses brasileiros adultos. A amostra constituiu-se de 60 fotografias laterais (30 homens e 30 mulheres) com oclusão normal, face balanceada e com idade entre 18 a 30 anos. Essa amostra foi comparada com um padrão de normalidade para leucodermas. Concluíram que os resultados achados podem servir como guia para o tratamento ortodôntico e cirúrgico, mas que o plano de tratamento deve ser individualizado para cada caso. 


\section{2 - Análise do perfil facial}

Em geral, os ortodontistas lideraram o campo da análise quantitativa da arquitetura dos tecidos moles da face, desenvolvendo normas e dados longitudinais importantes também para os cirurgiões bucomaxilofaciais.

Aceitando que a preferência estética de cada pessoa é estabelecida pela própria sensibilidade e pela influência do meio ambiente, pode-se afirmar que "a beleza está nos olhos de quem olha". A beleza pode ser definida como um estado de harmonia e equilíbrio das emoções faciais, estabelecidas pelas estruturas esqueléticas, pelos dentes e tecidos moles. ${ }^{34}$

Baseando-se numa linha reta que interceptava os pontos mais protuberantes da glabela e do mento, o britânico Woolnoth, em 1865, classificou o perfil facial em reto, côncavo e convexo. Esteticamente, para ele, o perfil côncavo e o convexo davam à pessoa uma aparência de maturidade precoce, envelhecendo-a mais rapidamente, e o perfil reto seria o mais agradável ${ }^{76,77}$.

A análise cefalométrica tornou-se de amplamente usada, não somente em pesquisas, mas também na prática clínica. Passou a ser utilizada, muitas vezes, como uma ferramenta indispensável para a análise das mudanças no crescimento em pacientes com deformidades dentofaciais e para o monitoramento dos procedimentos cirúrgicos. Desde os primeiros estudos, na década de 30 , diferentes análises cefalométricas se desenvolveram, formando um verdadeiro "mosaico" no diagnóstico cefalométrico ${ }^{44}$.

O primeiro registro de radiografias para estudar as características faciais foi realizado por CARREA, em 1942, com o objetivo de estudar o prognatismo mandibular adaptando um fio de chumbo mole ao perfil facial ${ }^{26}$.

Devido à grande importância da estética no diagnóstico ortodôntico do perfil e sua relação com o padrão dentoesquelético, RIEDEL ${ }^{89}$, em 1950, concluiu que o equilíbrio facial está relacionado com as bases apicais, o grau de convexidade 
do perfil facial ósseo e a relação dos incisivos com suas respectivas bases ósseas.

Em 1954, TWEED ${ }^{106}$, estudando os seus melhores casos, aperfeiçoou sua análise construindo seu famoso triângulo. Muitos de seus alunos alegavam encontrar dificuldades para alcançar os resultados estéticos por ele propostos. O triângulo foi formado pelo plano horizontal de Frankfort, pelo plano mandibular e pelo longo eixo do incisivo inferior. A estética facial seria obtida seguindo-se os valores normativos preconizados pelo autor. Concluiu que existem casos em que o exame clínico do perfil do paciente é que deve determinar o tratamento a ser instituído.

WYLIE ${ }^{112}$, em 1955, ao contrário de basear seu plano de tratamento na posição do incisivo inferior como TWEED ${ }^{106}$, pesquisou a correlação entre a inclinação dos incisivos inferiores e a alteração decorrente de sua movimentação no perfil tegumentar. Concluiu que as modificações do perfil por meio ortodôntico dependem não só dos dentes anteriores, mas principalmente do crescimento da mandíbula durante o tratamento. A posição do incisivo era, na verdade, uma conseqüência do tratamento, não determinando o resultado estético final. O estudo utilizou o material clínico e radiográfico fornecido pelo próprio Tweed, o mesmo no qual sua análise foi baseada.

STONER; LINDQUIST ${ }^{101}$, em 1956, verificaram que durante o tratamento ortodôntico ocorrem certas modificações do tecido mole e que os incisivos inferiores têm relação fixa com a estética facial, embora possa ser indireta. O estudo foi realizado com radiografias cefalométricas de 57 pacientes tratados por Tweed. Os autores relatam quatro modificações que teriam sido responsáveis pela principal melhora da aparência dos tecidos moles: 1) uma redução na proeminência dos lábios; 2) uma redução na curvatura do lábio inferior; 3) um aumento da dimensão vertical e 4) certo grau de projeção do mento, para anterior.

De modo similar RICKETTS ${ }^{86}$, em 1957, considerou que dentre os principais objetivos do tratamento ortodôntico estavam o equilíbrio e a harmonia da estética facial. $\mathrm{O}$ autor preconizou uma linha para a análise quantitativa da beleza facial, denominando-a de "plano estético" ou "linha E", que tangenciando a ponta do nariz e do mento tegumentar, avalia a posição dos lábios. Para sua determinação, analisou fotografias de artistas com excelentes perfis, constatando-se que o lábio 
superior e o inferior situam-se, respectivamente, 4 e $2 \mathrm{~mm}$ posteriormente ao "plano estético". Observaram que os lábios dos jovens do sexo masculino apresentaram-se um pouco mais retruídos em relação a essa linha, resultado de uma maior proeminência nasal e mentoniana. Destacou que essas medidas-padrão correspondem a pessoas adultas e que se devem considerar as mudanças durante o crescimento ao se planejar o tratamento ortodôntico.

SASSOUNI ${ }^{95}$, em 1958, destacou que o clínico pode obter melhores diagnósticos com a radiografia cefalométrica, o que não obteriam tão facilmente quando comparadas com os outros elementos de diagnóstico. Entretanto, ela não poderá orientar exatamente o que fazer, mas, pelo menos, sugere o mais apropriado.

WYLIE ${ }^{113}$, em 1959, concordou com a proposição de que o mento deve ser analisado em conjunto com o posicionamento do incisivo inferior, ao avaliar o seu efeito no perfil facial. Também considerou que não se deve basear em apenas um ângulo, extremamente sujeito a alterações no decorrer do tratamento, para planejá-lo integralmente. Entretanto, contestou a idéia de se criar uma fórmula para orientar o posicionamento do incisivo na determinação da estética facial. Diz o autor: "os ortodontistas tentaram, por vinte anos, fazer uma proposição científica para algo que pode ser apenas uma questão pessoal de gosto". Considerando que a preferência estética constitui uma questão pessoal e não contando com meios científicos para afirmar que uma face seja mais bela do que a outra, declarou que, como o julgamento dos artistas e dos ortodontistas é geralmente arbitrário, deve-se considerar também a preferência estética do público.

Baseado numa amostra de adolescentes e adultos jovens selecionada por artistas, BURSTONE ${ }^{22}$ apresentou um método para avaliar a espessura dos tecidos moles radiograficamente. Em seu estudo analisou a relação entre as más oclusões e a desarmonia facial e observou a importância das variações de espessura dos tecidos moles na determinação da harmonia facial, e que o tecido mole também pode mascarar uma discrepância dentoesquelética. Concluiu que um padrão de perfil ideal não pode ser determinado, pois o padrão varia de um grupo étnico ou raça para outro, como de uma pessoa para outra. 
RICKETTS $^{87}$, em 1960, submeteu à análise do seu "plano estético" mil casos, antes do tratamento ortodôntico. A maioria dos cirurgiões-dentistas consultados considerou que os lábios não devem ultrapassar essa linha para uma boa estética facial. Afirmou que a cefalometria, dentre as técnicas disponíveis, é o melhor método para auxiliar o diagnóstico e o plano de tratamento ortodôntico. Não obstante, referindo-se ao uso abusivo da análise cefalométrica, afirmou que "a análise quantitativa da radiografia constitui apenas uma parte de toda sua aplicação clínica; a análise cefalométrica não é uma fórmula para o tratamento, mas sim um método que descreve as condições existentes".

Ao revisar a história da beleza facial, HAMBLETON ${ }^{47}$, em 1964, observou que as principais características das faces, desde os egípcios, passando pelos gregos e romanos até os períodos influenciados pelos artistas franceses, italianos e alemães, modificaram-se durante os séculos e, como conseqüência, também ocorreram mudanças nos conceitos de beleza, balanço e harmonia. Sugeriu que ortodontista deveria se preocupar com a aparência dos tecidos moles, porém, não havia um padrão tegumentar a ser utilizado como meta de tratamento para todas as pessoas. Concluiu que, durante o processo do diagnóstico e planificação do tratamento ortodôntico, devia-se levar em consideração todos os aspectos que envolvem os tecidos moles da face, desde o seu crescimento até as modificações decorrentes das intervenções ortodônticas.

Para MERRIFIELD ${ }^{68}$ (1966), a oclusão normal e a harmonia facial seriam objetivos do tratamento ortodôntico interdependentes e que deveriam ser igualmente valorizadas. O ortodontista experiente teria condições de observar, visualmente, durante o tratamento, seus ganhos em direção a esses objetivos. O profissional menos experiente, entretanto, necessitaria de uma avaliação mais objetiva.

Em 1968, RICKETTS ${ }^{88}$ propôs a "Lei das Relações Labiais Normais". Afirmava que os lábios poderiam ser influenciados pelos dentes, ou que, inversamente, os dentes poderiam ser influenciados pelos lábios. A partir de dados obtidos de outras publicações e experiências comuns com o público, leigos e alguns artistas, observou que os adultos faziam objeção quanto aos lábios que passavam além do plano "E"; entretanto a proeminência da boca ou lábios cheios marca a juventude, enquanto que bocas com lábios planos sugerem mais idade. 
Utilizando as análises de Downs, Steiner e Ricketts, ALTEMUS ${ }^{3}$, em 1968 estudou as variações existentes entre indivíduos leucodermas, melanodermas, xantodermas, índios navajos e aborígenes australianos. Concluiu afirmando que a utilização de normas e padrões concebidos e desenvolvidos a partir do conceito de beleza de uma raça é imprópria para o tratamento de um paciente de uma raça diferente.

DRUMMOND ${ }^{37}$, em 1968, fez um estudo comparativo entre jovens melanodermas e leucodermas americanos, no qual afirmou que a posição protruída dos dentes e a espessura dos lábios fazem com que o terço inferior da face daqueles aparente ser mais volumoso. Pelo fato de o plano mandibular ter uma inclinação excessiva, o pogônio aparece pouco no contexto facial.

Interessado em propor medidas cefalométricas e compará-las com as padronizadas para leucodermas, SUSHNER, em $1977^{103}$, estudou 100 fotografias de perfil de americanos melanodermas divididos igualmente entre sexo masculino e feminino, selecionados por ortodontistas, como tendo os perfis mais agradáveis entre 1000 fotos. Verificou que os melanodermas apresentam um perfil tegumentar mais protrusivo que os leucodermas e, quanto ao dimorfismo, essa protrusão é maior nos homens que nas mulheres. Assim, o autor concluiu que a avaliação de perfis em melanodermas deve ser feita sem a imposição dos padrões para leucodermas.

FREITAS ${ }^{43}$, em 1978, desenvolveu um estudo cefalométrico em jovens leucodermas brasileiros. Comparou os perfis com as linhas preconizadas por Ricketts, Steiner, Holdaway, Burstone e Merrifield, avaliando qual ou quais dos métodos seriam mais eficientes na análise estética de brasileiros. Concluiu que as análises de Burstone e de Steiner foram as que melhor se relacionaram com os perfis faciais da amostra brasileira sob investigação. Ao comparar as medidas obtidas em sua amostra às propostas por Holdaway, constatou que o perfil facial tegumentar de adolescentes brasileiros do sexo masculino apresentou maior convexidade em relação ao dos norte-americanos. Quanto à análise de Ricketts, observou que seus valores podem ser aplicados apenas para as jovens do sexo feminino. 
Para verificar a aplicabilidade dos valores cefalométricos das análises de Downs, Tweed, Steiner e Alabama para os adolescentes brasileiros, MARTINS ${ }^{64}$, em 1979, utilizou uma amostra de 85 telerradiografias em norma lateral. Ao analisar as medidas pelo padrão esquelético de Steiner, o autor verificou que, surpreendentemente, as medidas do padrão esquelético da amostra de Bauru apresentaram médias similares às de Steiner e, quando submetidas ao teste " $\mathrm{t}$ " de Student, apresentaram-se não significantes, isto é, dignos de confiança e utilizáveis para a amostra paulista. Concluiu que os leucodermas brasileiros de origem mediterrânea podem apresentar o mesmo padrão esquelético dos leucodermas americanos de origem nórdica. Conseqüentemente, as medidas esqueléticas preconizadas por Steiner podem ser utilizadas para o diagnóstico e planejamento de tratamento dos jovens brasileiros com a mesma ascendência da amostra paulista. Quanto ao padrão dentário, o estudo demonstrou, sem muita surpresa, resultados díspares. O posicionamento dos incisivos superiores e inferiores, quando medidos angular e linearmente, evidenciaram que os jovens brasileiros apresentam uma protrusão mais acentuada quando comparada aos valores preconizados para os americanos.

HOLDAWAY ${ }^{49}$, em 1983, analisou a aplicação de onze medidas na avaliação da harmonia em perfis faciais. Concluiu que, dentre as características comuns de beleza facial, incluíam-se as seguintes: mento bem posicionado no perfil facial; nenhum problema de convexidade no perfil facial; lábio inferior com uma distância de $1 \mathrm{~mm}$ da linha $\mathrm{H}$ por ele proposta. Salientou ainda que as características e as relações entre beleza e atração eram relativas a cada cultura, pois até mesmo rainhas de beleza por ele avaliadas não possuíam oclusão ideal. Holdaway reconheceu também que, para o perfeito desenvolvimento psicológico e social dos pacientes, tem-se a obrigação de propiciar-Ihes o melhor equilíbrio e harmonia possíveis para suas linhas faciais.

No ano seguinte, HOLDAWAY ${ }^{50}$ concluiu que o plano de tratamento deve propor mudanças sob a perspectiva da análise do tecido mole, alterando os dentes somente na direção das melhores mudanças possíveis no perfil facial.

Diante dessas justificativas, McNAMARA JR. ${ }^{65}$, em 1984 , elaborou sua análise direcionando-a aos modernos métodos de cirurgia ortognática e terapia 
funcional. Essa metodologia, desenvolvida por ele na Universidade de Michigan, EUA, deriva em grande parte das análises de Ricketts e Harvold introduzindo alguns aspectos originais. Esse método relaciona as bases ósseas a uma linha que, partindo do násio, é perpendicular ao plano de Frankfort. Baseou-se em telerradiografias de três amostras diferentes, com boa harmonia entre dentes, ossos e perfil mole. Os grupos estudados foram: crianças compreendidas das amostras dos padrões de Bolton; crianças do Centro Ortodôntico de Burlington e um grupo formado por 111 adultos jovens tratados na Universidade de Michigan. A comparação dos valores obtidos no paciente em questão com as normas fornecidas nesses estudos permitiu detectar onde se encontra a discrepância esquelética. Em resumo, relacionam dentes com dentes, dentes com as bases ósseas, as bases ósseas entre si e ambas com a base craniana. Sugeriu ainda a utilização do ângulo nasolabial proposto por Scheideman como guia principal na definição da posição sagital da maxila.

Com o objetivo de desenvolver um método confiável e reproduzível para a mensuração do ângulo nasolabial e da relação entre o nariz e o lábio superior, FITZGERALD; NANDA; CURRIER ${ }^{40}$ propuseram a avaliação dos componentes do ângulo nasolabial em referência ao plano horizontal de Frankfort, analisados em 104 indivíduos de oclusão normal com boa estética facial. A comparação da reprodutibilidade pelos ortodontistas revelou que o método proposto para a construção do ângulo nasolabial mostrou-se consistente e de facil reprodução. Enfatizaram que, mesmo sendo um recurso para o diagnóstico ortodôntico, o ângulo nasolabial não deve ser utilizado radicalmente por não descrever com precisão as alterações do perfil tegumentar. Há casos em que esse ângulo encontra-se dentro de valores normais, mesmo o paciente possuindo protrusão labial e dentária.

Analisando 18 medidas exclusivas do tecido mole facial, importantes para o sucesso do tratamento ortodôntico, BERGMAN ${ }^{15}$, em 1999, verificou que as análises ortodônticas mais comuns baseavam-se em medidas esqueléticas e dentárias, dando pouca ênfase às medidas do tecido mole. Afirmou que um criterioso exame da face seria fundamental para entender as mudanças na aparência facial resultantes do tratamento ortodôntico, beneficiando o diagnóstico e o plano de tratamento. O conhecimento dos padrões faciais e das características específicas do tecido mole do indivíduo poderia levar à obtenção de normas 
individualizadas, que ajudariam a melhorar a atratividade facial.

CAPELOZZA FILHO $^{24}$ propôs uma nova forma de classificação das deformidades dentofaciais. Além da relação sagital dos molares, sugere uma classificação dentária ou baseada no envolvimento esquelético da má oclusão. O autor apresentou o conceito de padrão facial, que pôde ser definido como "a manutenção da configuração da face através do tempo". Nessa linha de pensamento, encontram-se indivíduos do Padrão I, II, III, face longa e face curta.

Referindo-se aos tecidos moles que recobrem a face LEGAM; BURSTONE $^{59}$, em 1980, afirmaram que os pacientes podem apresentar amplas variações individuais e, conseqüentemente, podem conduzir a análises incorretas se o diagnóstico e o planejamento do tratamento forem alicerçados somente em medidas dentoesqueléticas.

ARNETT; BERGMAN ${ }^{8}$, em 1993, publicaram um artigo com o título: "Chaves faciais para o diagnóstico ortodôntico e plano de tratamento", considerado um dos artigos de revisão mais completo sobre análise facial. Os autores apresentam 19 chaves faciais para funcionarem como ferramentas auxiliares, com o objetivo de aprimorar os resultados facial e dentário. A primeira parte direcionou-se para a forma de registro das informações do paciente, fundamental para se saber a extensão correta da deformidade. Enfatizaram o exame do paciente em posição natural da cabeça, com a oclusão em relação cêntrica e os lábios passivos. Os critérios estabelecidos podem ser aplicados para o exame facial clínico, tomada fotográfica e da telerradiografia em norma lateral. A segunda parte do artigo discutiu as diferentes relações entre os componentes faciais, em vista frontal e de perfil, correlacionando-os com o diagnóstico e plano de tratamento. Fizeram referência às desarmonias dentoesqueléticas comumente verificadas na clínica e como estas podem refletir no equilíbrio da face. Para os autores, a utilização de guias cefalométricos e de modelos isolados poderiam resultar em insatisfação do paciente, por entenderem que esses parâmetros não são sinônimos de privilégio estético. A correta compreensão dos traços faciais pode melhorar o diagnóstico, o plano de tratamento e a qualidade dos resultados, tanto dos pacientes cirúrgicos quanto dos não-cirúrgicos. 
Em comparação com os dados apresentados por ARNETT ${ }^{9}$, em 1993, a análise cefalométrica de tecido mole também se direciona para o exame do tecido tegumentar, mas com algumas vantagens. Os primeiros artigos sugerem a avaliação facial no exame clínico do paciente e, por isso, de precisão limitada. Com a análise feita com base na cefalometria, os pontos de referência no tecido mole podem ser localizados facilmente, marcados e avaliados.

NAIDOO; MILES ${ }^{71}$, em 1997, concluíram que os valores médios cefalométricos para as medidas de tecido mole de indivíduos sul-africanos se diferem dos indivíduos leucodermas norte-americanos.

Em 1999, ARNETT et al. ${ }^{10}$ apresentaram uma análise cefalométrica enfatizando as medições do tecido mole facial como um guia primário para o tratamento oclusal e para o plano de tratamento das deformidades dentofaciais. Os autores explicaram que a análise é um instrumento radiográfico desenvolvido como conseqüência da filosofia defendida em publicações passadas. Para tanto, 46 modelos leucodermas, sendo 20 homens e 26 mulheres, compreenderam a amostra. Todos os indivíduos possuíam oclusão normal e razoável equilíbrio facial, avaliados por um dos investigadores. Destaca-se em sua pesquisa a metodologia empregada: alguns detalhes anatômicos do terço médio, que normalmente não seriam mostrados na radiografia receberam marcadores metálicos posicionados no lado direito da face. Essas estruturas tornaram-se o alicerce no diagnóstico e plano de tratamento do terço médio facial. Em seguida, uma telerradiografia em norma lateral foi obtida, em posição natural da cabeça, com os côndilos assentados e lábios passivos.

Tornou-se possível um maior esclarecimento na comunicação com o paciente sobre os efeitos da cirurgia ortognática sobre o tecido mole. Programas de computador, com técnicas de manipulação de imagem específicas para os diferentes movimentos cirúrgicos, apresentaram-se como ferramentas fiéis no plano de tratamento. Essa nova tecnologia, indispensável nos dias atuais, permitiu ao clínico verificar o grau de satisfação dos pacientes com o resultado final antes mesmo de se submeterem ao tratamento. O termo "indispensável", embora de valor ousado, oferece emprego oportuno, visto que $71 \%$ dos pacientes que procuram tratamento ortodôntico-cirúrgico citam a estética como fator motivador ${ }^{92}$. 
Em 2003, PROFFIT; WHITE JR.; SARVER ${ }^{83}$ estabeleceram a expressão "paradigma do tecido mole". O termo paradigma pode ser interpretado como uma nova perspectiva baseada sobre uma estrutura científica emergente, com novos pensamentos e critérios e universalmente aceita. Para os autores, desde o início da especialidade, a teoria e prática ortodôntica basearam-se no paradigma de Angle. $\mathrm{O}$ objetivo de tratamento era produzir a oclusão perfeita dos dentes e, desse modo, a beleza facial naturalmente seria alcançada. Na ortodontia contemporânea, dá-se ênfase às considerações ao tecido mole, na sua relação com a estética facial, à teoria de equilíbrio muscular, determinante da estabilidade dos resultados, aos efeitos do movimento dentário sobre o suporte periodontal e à adaptação neuromuscular após o tratamento ortodôntico-cirúrgico.

Em um livro publicado recentemente, ARNETT; McLAUGHLIN ${ }^{11}$ descreveram de maneira sistemática e objetiva o plano de tratamento de pacientes que necessitam de tratamento ortodôntico ou orto-cirúrgico. Sob o título "Planejamento facial e dentário para ortodontistas e cirurgiões bucomaxilofaciais", os autores defenderam o equilíbrio e harmonia facial como objetivo principal de tratamento. Destacou-se a maneira sistemática e metódica como documentam as informações do paciente, essencial para a análise facial e planejamento do tratamento. Os autores afirmam, ao contrário do que foi apregoado no passado, que o movimento dentário deve ser determinado somente após o planejamento da face e da posição dos incisivos.

YEHEZKEL; TULEY ${ }^{114}$ (2004) avaliaram as modificações no perfil facial de mulheres afro-americanas, presentes nas revistas de moda, durante o século $X X$. Foram coletadas cento e dezenove fotografias de perfil em revistas de moda publicadas entre as décadas de 1940 e 1990, as quais foram divididas em seis grupos correspondentes a cada década estudada. Os autores observaram diferenças significantes entre a posição ântero-posterior dos lábios, no ângulo nasolabial e no ângulo interlabial, com aumento do volume e posição mais anterior dos lábios nas décadas mais recentes.

IOI et al. ${ }^{55}$ (2005) conduziram um estudo para determinar a percepção dos ortodontistas japoneses em relação a perfis atraentes da população japonesa adulta, com variação na convexidade facial e avaliar a variação da posição ântero- 
posterior do mento mole. Os perfis médios foram construídos a partir de uma amostra de trinta indivíduos japoneses com oclusão Classe I, igualmente distribuídos quanto ao sexo. Mudanças na convexidade facial foram estabelecidas pela alteração na posição ântero-posterior do mento mole, com incrementos de $5^{\circ}$ e $10^{\circ}$ a partir do perfil médio. Foram obtidas onze séries de silhuetas de perfil de cada uma das mudanças na convexidade facial. Observaram que os ortodontistas preferiram a posição dos lábios mais retruída quando a convexidade diminuiu, assim como lábios ligeiramente mais protruídos quando a convexidade aumentou, para ambos os sexos.

$\mathrm{RINO}^{91}$, em 2006, estudou a preferência do perfil tegumentar em indivíduos leucodermas, masculino e feminino, considerando a avaliação de ortodontistas, cirurgiões bucomaxilofaciais, cirurgiões plásticos, artistas plásticos, profissionais ligados à estética facial e leigos em conjunto e separados por grupo. Foram obtidas 2 fotografias coloridas do perfil direito de dois indivíduos, um do sexo masculino e outro do feminino. As fotografias foram digitalizadas, as imagens foram manipuladas por um programa de computador e o contorno dos perfis faciais, especificamente os contornos dos lábios e do mento mole, foi modificado no sentido horizontal e vertical, com incrementos de $4 \mathrm{~mm}$, com a finalidade de obtenção de outros perfis dos mesmos indivíduos. Concluíram que todos os avaliadores, em conjunto ou separados em grupos, consideraram o perfil equilibrado do sexo masculino o mais atraente, o perfil facial feminino equilibrado só não foi preferido pelo grupo leigo, que preferiu os perfis equilibrado, biprotrursão labial e protrusão do lábio superior. Os perfis faciais femininos convexos e côncavos, com alterações no mento mole e lábio inferior, foram considerados menos atraentes por todos os grupos avaliadores, enquanto os perfis masculinos com biprotrusão labial, retrusão do lábio superior e retrusão do mento mole foram escolhidos como os menos atraentes por todos os avaliadores.

\section{3 - Relação entre Tecido Tegumentar e Tecido Esquelético}

Os estudos das relações entre os tecidos moles e a estrutura 
dentoesquelética envolvem alguns dos mais proeminentes ortodontistas de nossa época.

Os ortodontistas têm como meta transformar uma má oclusão em uma oclusão funcional, proporcionando um perfil facial harmonioso. Entretanto, em alguns casos, a harmonia do perfil facial não é alcançada devido, na maioria das vezes, às variações de espessura e tonicidade do próprio tecido mole.

Para o diagnóstico e plano de tratamento da movimentação dentária, os valores cefalométricos normativos têm sido utilizados como importantes orientadores $^{20,44}$.

As vantagens da análise cefalométrica têm levado a uma forte confiança na cefalometria em todos os aspectos do tratamento ortodôntico, sendo muito utilizada para o diagnóstico devido à sua facilidade de obtenção, mensuração e comparação (superposição) das estruturas do tecido duro, e também pela crença de que o tratamento das alterações cefalométricas do tecido duro resulta numa face agradável $^{102}$.

Para o exame clínico é difícil a obtenção, mensuração e comparação das mudanças faciais, em comparação com os dados que se obtém comparado com o exame cefalométrico. Mas tem-se a consciência de que o exame clínico facial deve estar correlacionado ao exame cefalométrico durante o planejamento ortodôntico. Os valores considerados normais do exame facial estão disponíveis, mas não são utilizados tão claramente quanto os valores cefalométricos para direcionar as decisões no diagnóstico e no movimento dentário ${ }^{102}$.

No intuito de abordar os estudos $6,43,64,75,79$ realizados em indivíduos brasileiros, estes serão brevemente citados pela importância que representam na literatura, pela grande diversidade geográfica, variação de raças e miscigenação entre elas. Sendo assim, surge a necessidade de reconhecer que um único padrão de estética facial pode não ser apropriado para as decisões de diagnóstico e plano de tratamento para pacientes de vários passados étnicos.

Infelizmente, a confiança na análise cefalométrica para determinar o plano de tratamento algumas vezes conduz a problemas estéticos. Existem muitas 
explicações possíveis para a inadequação da cefalometria. A suposição de que a correção da oclusão, baseada em padrões cefalométricos, conduz à correção da estética facial nem sempre é verdadeira e pode, em alguns casos, conduzir a um resultado estético desfavorável. O tecido mole que recobre os dentes e osso pode apresentar uma variação tão grande que o padrão dentoesquelético pode ser inadequado em avaliar a desarmonia facial. Quando existe um desequilíbrio na espessura dos lábios, a desarmonia facial pode ser observada mesmo na ausência de desarmonias dentoesqueléticas ${ }^{49,50}$. O desequilíbrio facial pode ser associado com a inadequação labial ou redundância labial causada pelo comprimento do lábio, tecidos subjacentes fora de equilíbrio, ou um problema na espessura ou tônus do tecido. HAMBLETON ${ }^{47}$, em artigo que discorre sobre o tecido mole que recobre a face esquelética, comenta que a cortina facial é mais do que apenas o osso subjacente projetado no tecido mole: é também feito de músculos, tecido adiposo, nervos e vasos sangüíneos. BURSTONE ${ }^{21}$, em 1958, apresentou a idéia de que corrigir a discrepância dentária não necessariamente tratará o desequilíbrio facial e pode mesmo causar desarmonias faciais. DROBOCHY, SMITH ${ }^{36}$, em 1989, relacionaram os dados de 160 pacientes ortodônticos submetidos a extrações de quatro pré-molares e concluíram que as principais mudanças foram um aumento do ângulo nasolabial e retração dos lábios superior e inferior à linha E. Ao se compararem as mudanças do perfil com valores representativos de normalidade, constatou-se que as extrações não resultaram no perfil achatado, pois apenas $10 \%$ a $15 \%$ dos casos poderiam ser definidos como excessivamente achatados (dishedin) após o tratamento.

Em 1950, RIEDEL ${ }^{89}$ comentou que a relação das bases apicais no sentido ântero-posterior, o grau de convexidade do padrão esquelético da face e a relação dos dentes anteriores para com a face e com suas respectivas bases apicais têm influência marcante sobre o perfil do tecido mole.

GRABER $^{45}$, em 1956, afirmou que há uma tendência de simplificação da interpretação dos dados cefalométricos, comparando-os a um grupo conhecido por "valores normais", e que um paciente pode apresentar valores que não estão dentro desses valores normais e ainda assim apresentar harmonia facial ou um discreto problema facial, apesar de não estar dentro da "norma". 
Depois de publicar vários artigos sobre o perfil esquelético oculto sob os tecidos moles, DOWNS ${ }^{35}$ publicou, em 1956, um artigo no qual procurava associar a telerradiografia à fotografia de cada paciente com a finalidade de determinar os tipos faciais. Para tanto, era necessário um plano que pudesse ser evidenciado na telerradografia e na fotografia. O plano de referência escolhido foi o plano horizontal de Frankfort, apesar da dificuldade de localização precisa do meato acústico externo e do pório.

Associando medidas cefalométricas utilizadas até então com a estética, POULTON(1957) ${ }^{82}$ testou algumas medidas propostas por Steiner e Downs em pacientes jovens, de ambos os sexos, portadores de oclusão normal e bom perfil facial. Para isso, utilizou fotografias laterais da face, que foram oferecidas a dez membros do corpo ortodôntico da Universidade da Califórnia, para apreciação de ordem estética. Cada um deles colocou as fotografias em ordem decrescente, segundo a sua preferência. Contudo, somente as oito primeiras fotografias e as oito últimas de cada sexo foram aproveitadas na pesquisa, e nas radiografias cefalométricas correspondentes foram medidos ângulos recomendados por diversas análises. Os ângulos preferidos pelo autor para estudos de correlação em estética facial, de acordo com os resultados desse estudo são SNA, o ângulo de convexidade NAP e a relação incisivo inferior com o plano mandibular.

BURSTONE ${ }^{21}$, em 1958, enfatizou a importância da avaliação dos tecidos moles da face, com especial atenção para o perfil. Afirmou que o terço inferior da face não serve apenas para as funções da fala, mastigação, deglutição e respiração, mas também influencia muito a aceitação social e psicológica do indivíduo. Para o autor, aparência é uma das principais funções da face. A noção de que o perfil facial ideal difere de pessoa para pessoa, de um grupo racial para outro, das mudanças que ocorrem ao longo dos séculos e da experiência visual do indivíduo ou dos grupos torna a identificação do perfil ideal muito difícil. Outro fato importante é a participação da mídia da massa, televisão, cinema e entretenimentos de um modo geral, como apresentar ao público faces consideradas belas. O impacto dessa mídia tem sido tão grande que os indivíduos de vários grupos raciais, os quais teoricamente deveriam ter seus próprios conceitos de beleza facial, acabam aceitando o padrão de Hollywood como excelência facial. Em suma, aos olhos do observador, a harmonia do perfil não envolve apenas um arranjo médio de todos os 
componentes, mas a variação aceitável ao redor dessa média.

Complementando seu trabalho sobre medidas angulares do perfil tegumentar publicado em 1958, BURSTONE ${ }^{22}$ desenvolveu, em 1959, uma análise baseada em medidas lineares com o objetivo de avaliar a espessura e o comprimento das estruturas faciais, pois um tratamento baseado em medidas dentoesqueléticas pode não apresentar resultados esteticamente favoráveis. Outra afirmação do autor diz respeito à correlação existente entre estética e estabilidade; o mesmo desequilíbrio muscular que pode determinar a instabilidade do caso pode provocar algum tipo de desarmonia facial. Com os resultados obtidos, o autor concluiu que existe grande variação na constituição do tecido mole que recobre a face e essa constituição ainda apresenta diferenças entre os sexos masculino e feminino e entre as faixas etárias estudadas - adolescentes e adultos jovens. Concluiu que o tratamento ortodôntico sem o conhecimento e aplicação individual de informações relativas ao perfil dos tecidos moles pode aumentar a desarmonia facial ou substituir um tipo de desarmonia por outro.

Em 1959, NEGER ${ }^{73}$ propôs um método fotográfico para avaliação dos tecidos moles da face. Selecionou uma amostra de indivíduos leucodermas norteamericanos com oclusão excelente, para estabelecer as medidas de referência. Utilizou fotografias padronizadas em preto e branco, obtidas com o plano horizontal de Frankfort paralelo ao solo e o plano sagital do paciente paralelo ao filme. Sobre as fotografias foram traçadas linhas e planos de orientação, e medidas angulares foram utilizadas para avaliar a posição dos lábios superiores e inferiores e do mento. Os resultados mostraram que o perfil facial reto não necessariamente acompanha a oclusão excelente e que há grande variabilidade no tegumento que recobre as faces da população estudada. Concluiu que as análises cefalométricas, baseadas em normas obtidas a partir das estruturas dentoesqueléticas, não fornecem informações precisas sobre as relações dos tecidos moles da face.

BOWKER; MEREDITH ${ }^{19}$, em 1959, realizaram um estudo comparativo de medidas lineares a partir de cinco pontos do perfil mole em relação com a linha násio- pogônio do perfil ósseo. O objetivo principal desse estudo foi o de estabelecer um método métrico para descrever o perfil mole da face. 
Em 1963, LUSTERMAN ${ }^{61}$ analisou diferentes tipos raciais, empregando medidas dentoesqueléticas referentes à espessura, altura e inclinação do perfil mole. Em uma de suas conclusões, assinalou que a mais importante característica relacionava-se aos tecidos moles, nos quais foram considerados o volume e a inclinação dos lábios. Salientou, ainda, que se deve ter em mente as diferenças entre as raças para individualizar cada caso a ser tratado.

WILLIANS ${ }^{109}$, em 1969, comentou que o que tornou tão valiosas as contribuições de TWEED para a análise cefalométrica foi a sugestão de que existia uma correlação entre o ângulo do incisivo inferior e tecido mole. Defendeu o valor da linha AP como critério para avaliação do equilíbrio dos lábios. De acordo com esse autor, quando a borda incisal do incisivo inferior coincidir ou se posicionar levemente para trás da linha AP, esta posição estaria correlacionada com um contorno labial harmonioso.

Considerando que no Brasil coexistem diversas raças, MACHADO FILHO $^{62}$, em 1969, examinou 69 brasileiros do sexo masculino, de diversas origens, com o intuito de relacionar os tecidos moles com os duros. Concluiu que não se pode padronizar as relações dentoesqueléticas com perfil tegumentar quando não se associa cada paciente com sua origem racial.

Cada cultura possui preferência estética diferente em períodos históricos específicos. PECK; PECK ${ }^{77}$, em 1970, numa retrospectiva história, citaram Platão e Aristóteles como principais filósofos gregos a se preocuparem com leis geométricas que regeriam a harmonia da face mediante o respeito a determinadas proporções fixas. Sabe-se também que quanto mais um determinado padrão facial é observado, mais é considerado como correto, razão pela qual as pessoas geralmente comungam um senso comum quanto à apreciação da beleza facial apesar das diferenças de nacionalidade, idade e sexo. Esses autores reconhecem, então, que o senso estético é o produto de diversos fatores culturais que conduzem a certa unificação das preferências individuais. Conseqüentemente, há uma tendência, prevalente entre ortodontistas, de desenvolver em nossas mentes um conceito de estética facial.

Até esse momento, todas as pesquisas desenvolveram-se com amostras 
de indivíduos com "oclusão normal" e perfil facial agradável. Em uma abordagem diferente, COX; VAN DER LINDEN ${ }^{30}$, em 1971, realizaram uma pesquisa para avaliar a harmonia facial de indivíduos leucodermas holandeses de ambos os sexo, selecionados independentemente da atratividade facial. Fotografias na vista de perfil, em posição natural da cabeça, obtidas com técnica apropriada, evidenciaram o contorno dos perfis faciais. A partir dessas fotografias, ortodontistas e leigos selecionaram quatro grupos de indivíduos, homens e mulheres, quanto à estética do perfil facial. O resultado dessa seleção revelou não haver diferenças entre suas preferências. Desses indivíduos foram obtidas telerradiografias laterais para análise das medidas relativas aos tecidos moles e esqueléticos da face. Verificaram grande variação no grupo de indivíduos com boa estética facial, além de um grande número de faces atraentes associadas com más oclusões. Concluíram que os perfis considerados menos equilibrados, tanto no sexo masculino quanto no feminino, são aqueles relacionados às faces convexas.

WORMS et al. ${ }^{110}$, em 1976, afirmaram que os indivíduos com um relacionamento ântero-posterior esquelético inadequado e/ou dentário podem apresentar contornos do tecido mole normais ou próximos da normalidade. Por outro lado, pacientes com relação dentária e esquelética normais podem apresentar os contornos dos tecidos moles da face anormais. Concluíram que os contornos de tecido mole podem ser melhorados corrigindo-se as relações esqueléticas e/ou dentárias. Reconheceram, ainda, a importância dos tecidos moles para as análises das deformidades dentofaciais.

Com uma amostra de 56 telerradiografias de adultos jovens, leucodermas de ambos os sexos, portadores de relacionamento ósseo e dentário harmônicos, sem tratamento ortodôntico prévio e proporções faciais equilibradas, SCHEIDEMAN et al. $^{97}$ propuseram estabelecer valores considerados normais para os tecidos tegumentar, ósseo e dentário em uma população adulta, determinando uma série de valores cefalométricos para utilização no diagnóstico e planejamento de cirurgias de pacientes portadores de desarmonias dentoesqueléticas.

CONNOR; MOSHIRI ${ }^{28}$, em 1985, compararam uma amostra de 50 indivíduos melanodermas com uma amostra de 50 indivíduos leucodermas, ambos com "oclusão normal" e perfil harmônico. Encontraram para os indivíduos 
melanodermas maior prognatismo maxilar, maior altura dentária anterior, maior vestibularização dos incisivos inferiores e maior comprimento do lábio superior. Concluíram que seu estudo pode ser usado como auxiliar nos diagnósticos dos tratamentos ortodônticos e das cirurgias ortognáticas.

Percebendo que as análises cefalométricas preconizadas e universalmente utilizadas para melanodermas apresentam os mesmos inconvenientes para os leucodermas, BERTOZ; MARTINS ${ }^{16}$, em 1981, obtiveram uma amostra de 30 telerradiografias em norma lateral, de jovens brasileiros, melanodermas, dos 12 aos 17 anos, com "oclusão normal", para estabelecer o valor normal da Linha "I", em indivíduos com as características da sua amostra e compará-lo ao preconizado originalmente por INTERLANDI ${ }^{54}$, para brasileiros, leucodermas, de ambos os gêneros e da mesma região. Encontrou que os incisivos inferiores dos jovens da raça negra mostraram-se excessivamente inclinados para vestibular, quando comparados com os da raça branca, concluindo que cada grupo necessita de medidas cefalométricas próprias.

Estudando o relacionamento do perfil facial esquelético e a forma do nariz, ROBISON; RINCHUSE; ZULLO ${ }^{93}$, em 1986, utilizaram uma amostra de 123 jovens do sexo feminino, com idades entre 11 e 20 anos, sem história prévia de patologia, trauma, intervenção cirúrgica ou tratamento ortodôntico. A classificação do perfil esquelético facial baseou-se na relação entre a maxila e a mandíbula, dividindo-se em perfil reto, côncavo ou convexo. Pôde-se observar que mais de 86\% da amostra demonstrou uma alta correlação entre a forma nasal e o perfil esquelético, ou seja, os jovens com perfil reto exibiram um contorno nasal reto, um perfil convexo denotou um nariz convexo e um perfil côncavo foi observado com uma forma nasal igualmente côncava. Os autores enfatizaram a importância do equilíbrio facial total, especialmente da forma nasal, durante o diagnóstico e o planejamento ortodôntico e, ainda, que os ortodontistas deveriam considerar algumas combinações em seus diagnósticos e planos de tratamento, pois a mudança de um aspecto do complexo facial pode alterar toda a harmonia.

MEDEIROS ${ }^{67}$, em 1986, objetivou determinar o padrão cefalométrico dentário para jovens melanodermas brasileiros, do sexo feminino, e o dimorfismo entre os sexos. A amostra apresentava "oclusão normal", sem interferência de 
tratamento ortodôntico, e foi dividida em 3 grupos: Grupo I, formado por 30 telerradiografias cefalométricas de melanodermas do sexo feminino dos 11 anos e 5 meses aos 18 anos e 6 meses; Grupo II, composto pelos dados cefalométricos de 43 leucodermas do sexo feminino, dos 11 anos e 5 meses aos 14 anos e 11 meses e Grupo III, constituído pelo valor médio da Linha "I" de 30 melanodermas do sexo masculino, dos 12 aos 17 anos. Concluiu-se que os jovens do Grupo I apresentaram uma protrusão e inclinação vestibular acentuadas dos incisivos, principalmente dos inferiores, quando comparadas às do Grupo II e não ocorreu dimorfismo entre os sexos entre os jovens dos Grupos I e III, quando comparado pela Linha "I", de INTERLANDI ${ }^{54}$.

Em 1986, PARK; BURSTONE ${ }^{76}$ avaliaram o resultado estético de trinta pacientes tratados ortodonticamente, de acordo com normas estéticas. Foram incluídos na amostra pacientes que terminaram o tratamento apresentando distância linear de até 1,5 mm entre a borda do incisivo inferior e a linha A-Pog. Compararam a média dessa medida para a amostra tratada com a média da amostra com oclusão normal da Indiana University e observaram grande variabilidade nas medidas tegumentares dos pacientes tratados. Essa observação induziu os autores a concluir que o planejamento ortodôntico baseado em medidas esqueléticas, sem considerar a avaliação facial, pode apresentar resultados desastrosos.

MORAES; FREITAS; HENRIQUES ${ }^{69}$, em 1988 desenvolveram um estudo cefalométrico em uma amostra de melanodermas brasileiros do sexo feminino, com "oclusão normal" e não tratados ortodonticamente. Essa amostra foi comparada com um padrão de normalidade para leucodermas. Observaram que nas melanodermas a maxila e a mandíbula apresentavam-se mais protruídas em relação à base do crânio, que o perfil foi acentuadamente convexo, a sínfise mentoniana retruída e o padrão do esqueleto cefálico mostrou-se semelhante aos leucodermas.

Em 1989, CAPELOZZA FILHO et al. ${ }^{25}$ testaram a validade da análise de McNAMARA $^{66}$ no diagnóstico das desarmonias dentofaciais, analisando 3 grupos de pacientes: um com deficiência mandibular, um com excesso mandibular e um com face longa. Foram analisados com e sem a adoção do ângulo nasolabial como parâmetro de diagnóstico. O índice de concordância deste diagnóstico com o tratamento adotado foi muito maior com o uso do ângulo nasolabial como parâmetro 
para determinar a posição da maxila. No entanto, apresentou uma forte tendência em aumentar os valores da discrepância, mais do que aqueles que seriam inferidos pelo cirurgião, exceto para o avanço mandibular nos casos de Classe II com retrusão mandibular. Verificaram também que os casos de discrepâncias dentoesqueléticas necessitam de avaliação facial, além da análise cefalométrica convencional. A avaliação baseada nos ângulos SNA, SNB e ANB não foi confiável em casos de alteração na altura do $1 / 3$ inferior da face e, apesar de a avaliação de Wits apresentar boa capacidade de leitura, deve ser complementada por análises adicionais, exatamente por não localizar a origem exata das deformidades.

BITTNER; PANCHERZ ${ }^{17}$ procuraram determinar se as anormalidades sagitais e verticais no relacionamento intermaxilares, interincisivos superiores e inferiores refletem-se na morfologia facial. Cento e setenta e duas crianças entre 12 e 14 anos de idade foram selecionadas do departamento de ortodontia, da Universidade de Giessen. Fotografias faciais de frente e de perfil e de radiografias laterais do crânio foram realizadas e, em seguida, efetuada uma avaliação pessoal da relação interincisivos e intermaxilar por meio do exame visual de fotografias faciais, e também comparações entre as medidas angulares e lineares sobre fotografias e radiografias. Os resultados revelaram que apenas os grandes trespasses horizontais foram reconhecidos de modo confiável nas fotografias faciais, e condições de sobremordida não puderam ser verificadas. As más oclusões de Classe II divisão 2 refletem-se mais freqüentemente na face do que as más oclusões de Classe III. Os autores comentaram ainda que parece não ser apropriado corrigir a má oclusão lutando contra parâmetros cefalométricos esqueléticos. Do ponto de vista estético, por exemplo, nas más oclusões Classe II, $1^{\mathrm{a}}$ divisão, com maxilas prognatas, o tratamento à custa do avanço mandibular parece ser apropriado, uma vez que de fato o prognatismo maxilar geralmente não se reflete na aparência facial.

A análise facial representa, segundo ARNETT; BERGMAN ${ }^{9}$, a chave do diagnóstico de uma deformidade dentofacial, e seu papel nesse diagnóstico tem aumentado com o passar dos anos, chegando a ponto de se sobressair em relação à análise cefalométrica, ficando esta responsável por confirmar o diagnóstico facial.

VIAZIS ${ }^{108}$, em 1993, verificou relação existente entre o estabelecimento do perfil facial tegumentar estético e a obtenção de uma oclusão normal, salientando 
a importância que a beleza e a atratividade facial desempenham na sociedade. Preconizou também a utilização do plano horizontal verdadeiro como o parâmetro mais indicado para a realização das tomadas radiográfica e fotográfica nas pesquisas sobre as alterações craniofaciais e tegumentares. Afirmou que uma avaliação completa do tecido facial tegumentar permite ao profissional um melhor discernimento a respeito dos problemas dentoesqueléticos que cada paciente possa apresentar.

CZARNECKI; NANDA; CURRIER(1993) ${ }^{31}$ determinaram que dentre os fatores que deviam ser considerados na determinação do grau de protrusão labial aceitável para cada pessoa estariam a projeção nasal e a mentoniana. Segundo eles, geralmente se aceita uma maior protrusão labial, em ambos os sexos, nos perfis com nariz ou mento muito desenvolvidos. Uma protrusão labial três vezes maior é também aceitável nos casos com um mento bastante protruído, em relação a um nariz muito saliente.

Para ANDREWS ${ }^{4}$, em 1997, os iniciantes em ortodontia serão capazes de estabelecer um diagnóstico utilizando tanto a cefalometria tradicional como o método cefalométrico dos seis elementos da harmonia orofacial, mas por razões diferentes. A abordagem dos seis elementos é melhor para o diagnóstico do que a utilização das médias desenvolvidas a partir de normas computadorizadas, porque utiliza novos pontos de referência, os quais resultarão em tratamentos ântero-posteriores individualizados para cada paciente. Para o autor, a superioridade da abordagem dos seis elementos é óbvia. A cefalometria tradicional só não será obsoleta para a avaliação dos resultados do tratamento por meio das sobreposições, pois nesse caso os referentes são únicos para cada indivíduo. Afirmou, ainda, não existir correlação entre os referentes da cefalometria convencional e o que é esteticamente único para cada paciente.

IAGUE NETO ${ }^{53}$, em 1998, avaliou a relação entre o perfil facial tegumentar e as estruturas dentoesqueléticas maxilomandibulares. Utilizou uma amostra de 49 telerradiografias tomadas de adultos jovens, sendo 27 do sexo feminino (média de 17a 9m) e 22 do sexo masculino (média de 17a 10m), com oclusão normal e boa estética facial. De acordo com os resultados obtidos, observou que o perfil facial tegumentar, avaliado por meio de medidas angulares, não 
demonstrou um dimorfismo entre os dois sexos. Houve uma correlação entre a linha dentoalveolar superior, tomada do ponto A ao ponto vestibular do incisivo superior, e a inclinação do lábio superior. A inclinação do incisivo inferior em relação à linha $\mathrm{N}$ perpendicular ao plano de Frankfort (Nperp) influenciou a inclinação do lábio inferior.

ARNETT $^{7}$, em 1998, relata em um entrevista que o diagnóstico da má oclusão através de normas cefalométricas não é confiável. A suposição de que a correção da má oclusão baseada em valores normativos cefalométricos proporcionava uma estética facial adequada não era sempre verdadeira, podendo algumas vezes levar o profissional a resultados abaixo das suas expectativas e das expectativas do indivíduo. Como explicações possíveis para a inadequação da cefalometria destacam: o tecido mole que recobre dentes e osso pode variar tanto que o padrão dentoesquelético pode ser inadequado na avaliação da desarmonia facial; quando a base craniana é utilizada como linha de referência para medir o perfil facial, podem ser gerados dados adulterados; cada estudo cefalométrico examina diferentes medidas como sendo a chave para o diagnóstico. Portanto, quando análises cefalométricas diferentes são utilizadas para examinar o mesmo diagnóstico, podem ser gerados diagnósticos, planos de tratamento e resultados diferentes. Conclui que a cefalometria possa ser um recurso mais confiável como um meio de predição das alterações teciduais quando não houver uma desarmonia esquelética.

BERGMAN $^{15}$, em 1999, discutiu sobre 18 medidas exclusivas do tecido mole facial, importantes para o sucesso do tratamento ortodôntico. As análises ortodônticas mais comuns baseavam-se em medidas esqueléticas e dentárias, dando pouca ênfase às medidas do tecido mole. Um exame da face seria fundamental para se entender as mudanças na aparência facial resultantes do tratamento ortodôntico, bem como para beneficiar o diagnóstico e o plano de tratamento. Afirmou que o conhecimento dos padrões faciais e das características específicas do tecido mole do indivíduo poderia levar à obtenção de normas individualizadas que ajudariam a melhorar a atratividade facial. O tecido mole que cobre os dentes e ossos poderia variar muito e que normas dentárias e esqueléticas seriam guias inadequados para a harmonia facial. Era comum considerar-se que, quando os dentes estivessem em um padrão ideal, o tecido mole automaticamente estaria em uma posição harmônica. A estética facial, porém, não dependia apenas 
do tecido duro; as dimensões do tecido mole variavam com a espessura, com o comprimento labial e com o tônus muscular, sendo necessário, portanto, um estudo do contorno do tecido mole para se avaliar adequadamente a harmonia facial. $O$ autor afirmou que, para predizer a resposta do tecido mole em relação às mudanças no tecido duro, o ortodontista deveria entender o comportamento do tecido mole no tratamento ortodôntico e no crescimento e desenvolvimento da face. Muitos fatores influenciavam as características faciais, tais como o padrão esquelético, o padrão dentário, a espessura do tecido mole, a etnia e as diferenças de sexo e de idade. Portanto, para se obter sucesso no tratamento, todos esses fatores deveriam ser considerados. As normas faciais eram usadas para definir o que era aceitável e também para estabelecer valores que deveriam ser usados apenas como guias, sendo que exceções deveriam ser feitas em certos indivíduos devido às suas características particulares, que poderiam representar traços familiares.

UCHIAMA $^{107}$, em 2005, desenvolveu um trabalho com o propósito de apresentar um padrão cefalométrico específico para jovens brasileiros melanodermas. Esse estudo objetivou obter os valores médios de normalidade para algumas das grandezas cefalométricas esqueléticas, no sentido vertical da face, (alturas faciais anterior e posterior) e verificar a presença de dimorfismo entre os sexos. A amostra constituiu-se de 56 telerradiografias, em norma lateral, sendo 28 do sexo masculino, com idade média de 13,93 anos, e 28 do sexo feminino, com idade média de 13,79 anos, obtidas de amostra de jovens brasileiros, melanodermas, não submetidos a tratamento ortodôntico e que apresentavam "oclusão normal". Pôde-se observar a presença de dimorfismo, com os valores das grandezas AFAT, AFAS, AFPS, AFPS, além das proporções AFPS/AFPT e AFPI/AFPT significantemente alterados. Concluiu-se que os melanodermas do sexo masculino apresentaram as alturas faciais anterior e posterior maior do que as melanodermas.

PINZAN $^{80}$, em 2006, observou a influência dos pontos cefalométricos, das diferenças entre os sexos, idades, grupos raciais e más oclusões, na interpretação da telerradiografia, destacando a importância da associação entre cefalometria e fotografias extrabucais no diagnóstico e plano de tratamento ortodôntico. 
3 - PROPOSIÇÃO 



\section{3 - PROPOSIÇÃO}

O objetivo deste trabalho foi analisar comparativamente medidas da análise cefalométrica dos tecidos moles de pacientes leucodermas norte-americanos com pacientes feodermas brasileiros utilizando o software Dolphin ${ }^{\circledR}$, considerando:

a) Medidas dentoesqueléticas;

b) Estruturas do tecido mole;

c) Comprimento Facial;

d) Projeção em relação à Linha Vertical Verdadeira . 



\section{4 - MATERIAL E MÉTODOS}





\section{4 - MATERIAL E MÉTODOS}

A amostra estudada neste trabalho foi constituída por dois grupos: controle e grupo experimental.

\subsection{Amostra}

\subsubsection{Grupo Controle}

Os dados cefalométricos usados no grupo controle foram descritos por ARNETT et al. ${ }^{10}$, obtidos de 46 pacientes caucasianos adultos, (20 homens e 26 mulheres), os quais foram digitalizados e então calculados os valores médio de desvio-padrão e de probabilidade. Todos os pacientes apresentavam oclusão de Classe I não tratada ortodonticamente e foi realizada uma distinção entre a qualidade das partes da face (cabelo, olhos, pele, etc.) e posição das mesmas.

\subsubsection{Grupo Experimental}

A formação do grupo experimental seguiu os seguintes parâmetros de inclusão.

1. Feodermas

2. Apresentação de faces consideradas harmônicas

3. Portadores de oclusão normal, sem mutilações nos arcos dentários

4. Nunca submetidos a tratamento ortodôntico

5. Idade entre 18 e 35 anos

6. 19 do sexo masculino 20 do feminino 


\section{2 - Métodos}

\subsection{1 - A obtenção das Radiografias Cefalométricas}

Antes da tomada radiográfica cefalométrica, os pacientes do grupo experimental foram avaliados clinicamente em posição natural da cabeça, com os côndilos assentados e os lábios em repouso. O posicionamento correto do paciente e o exame clínico foi realizado, conforme proposto por ARNETT; BERGMAN ${ }^{11}$, com ênfase especial para as estruturas do terço médio da face que não aparecem na análise cafalométrica padrão. Em particular, o contorno da rima infraorbitária, da maçã do rosto, a região subpupilar e a base alar foram observadas para indicar a posição ântero-posterior da maxila.

Previamente às tomadas radiográficas, pequenos marcadores metálicos foram colocados no lado direito da face (Figura 1) para marcar na radiografia as estruturas-chave do terço médio da face (Figura 2). Essas estruturas essenciais da face média, embora perdidas nas radiografias convencionais, foram ressaltadas com a utilização desses marcadores, tornando-se um passo fundamental para o diagnóstico e tratamento das deficiências do terço médio da face. Também foi colocado um marcador na linha mento-pescoço (Figuras 1 e 2).

Após os passos descritos anteriormente, todos os pacientes foram radiografados utilizando-se o aparelho Rotograph plus.

As radiografias foram realizadas utilizando-se sempre o aparelho de raio$X$ do Departamento de Estomatologia da Faculdade de Odontologia de Bauru - FOB - USP. 


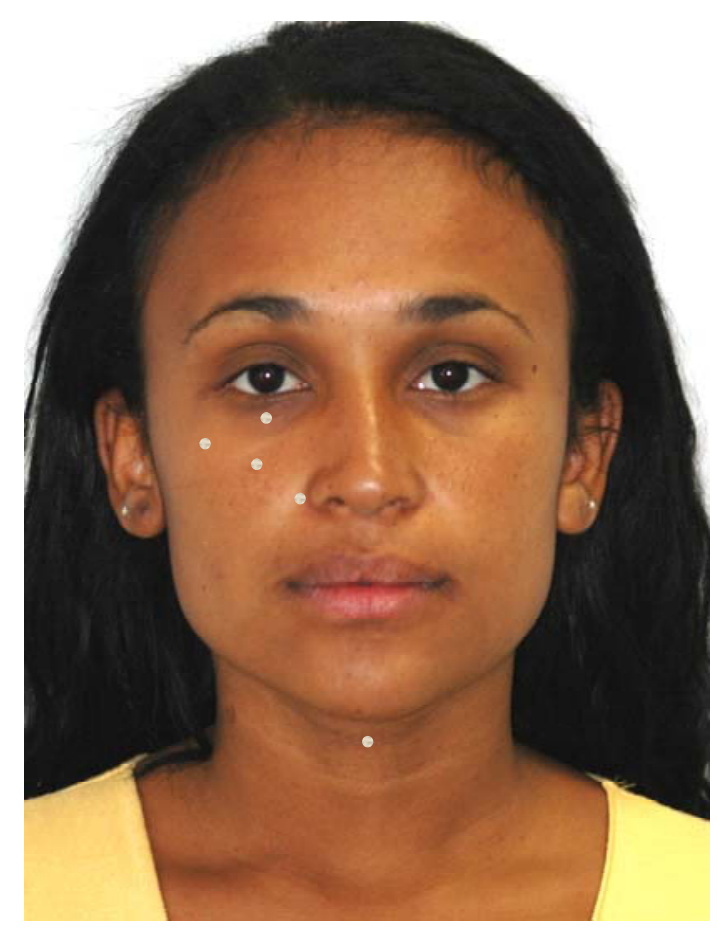

Figura 1 - Marcadores metálicos posicionados para a realização da telerradiografia. De cima para baixo, os marcadores estão posicionados nos pontos cefalométricos da rima orbitária, ponto da maçã, ponto da região subpupilar, base nasal e ponto da linha mento-pescoço.

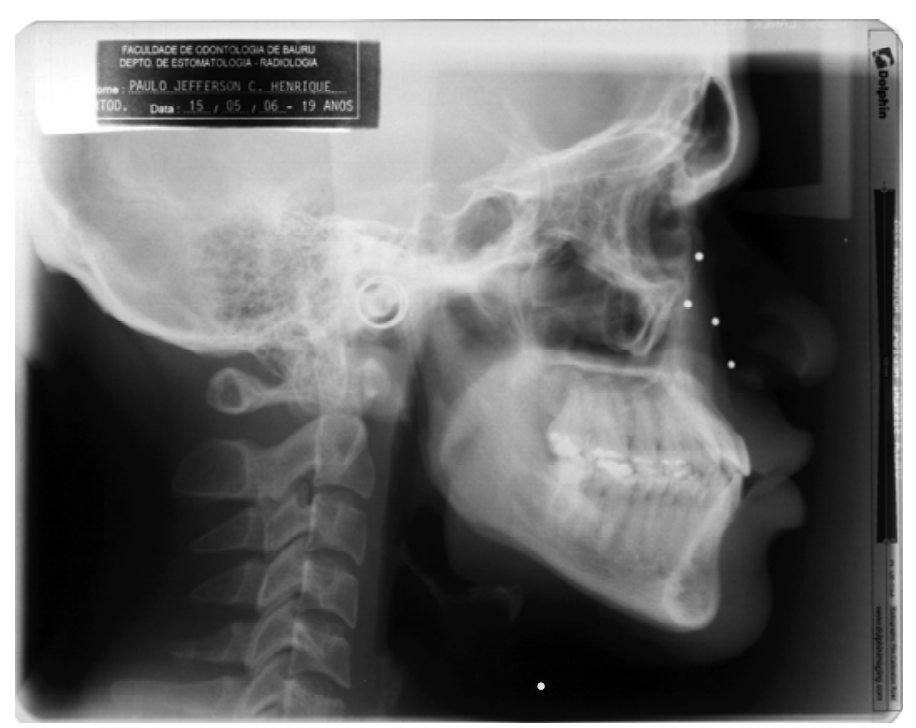

Figura 2 - Visualização dos marcadores metálicos na radiografia telelateral. De cima para baixo os marcadores posicionados nos pontos cefalométricos da rima orbitária, ponto da maçã, ponto da região subpupilar, base nasal e ponto da linha mento-pescoço. 



\subsection{2 - A Elaboração dos Cefalogramas}

As telerradiografias foram escaneadas com o Scanner Agfa Arcus II (Agfa, Morfsel, Bélgica), utilizando o programa Agfa Fotolook 3.5, no sistema RGB, com resolução de $200 \%$ de ampliação e 225 dpi. Todas as radiografias foram digitalizadas com o auxílio de uma régua própria do Dolphin (Figura 3), utilizada para se corrigir a magnificação da imagem radiográfica causada durante a exposição dos filmes cefalométricos. As imagens foram ajustadas no programa Adobe-Photoshop 7.0 (Adobe System, San Diego, Estados Unidos) e, posteriormente, indexadas no programa Dolphin Imaging, versão 9.0(Figura 4), no qual puderam ser ampliadas em até $200 \%$ sem perda de qualidade. A demarcação dos pontos de referência dentoesqueléticos e o traçado anatômico que compõem o cefalograma foram realizados digitalmente em ambiente de penumbra. Quando as estruturas bilaterais não eram coincidentes, efetuou-se o traçado médio entre as imagens (Figura 5).

Figura 3 - Régua própria do Dolphin. 



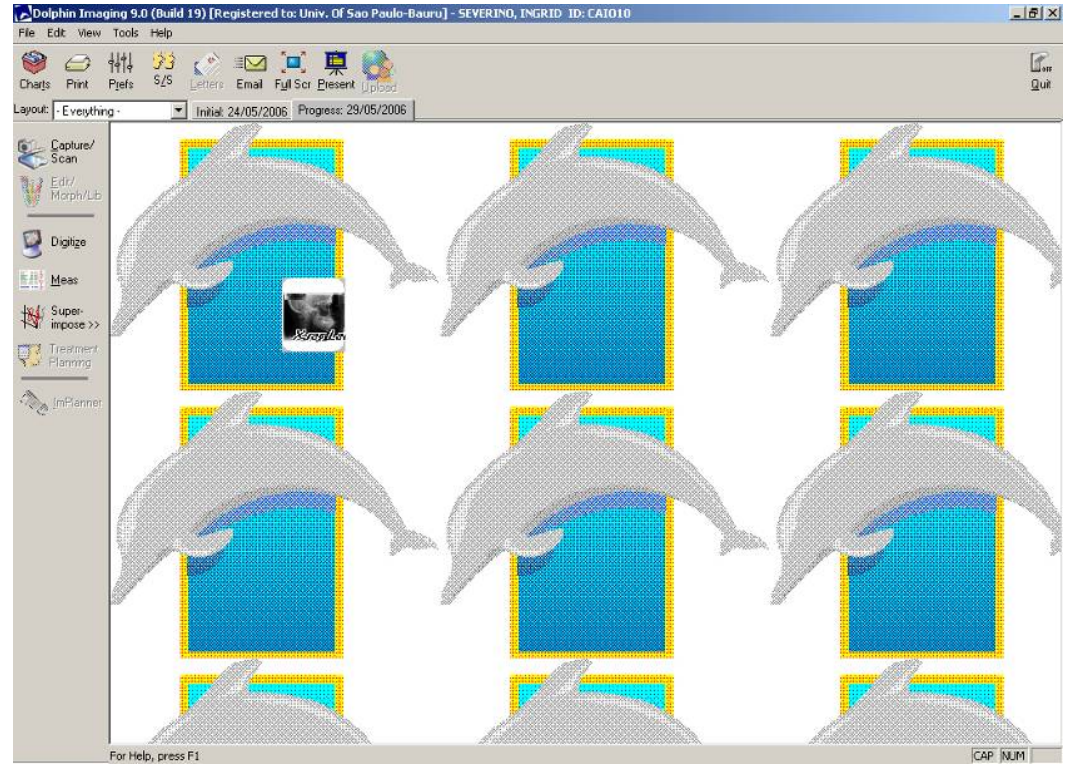

Figura 4 - Interface do software Dolphin Imaging, versão 9.0



Figura 5 - Interface do software Dolphin Imaging, versão 9.0 mostrando o cefalograma. 



\subsection{3 - Delimetação do desenho Anatômico}

Foram delimitadas as seguintes estruturas (Figura 6):

- ossos nasais e frontal;

- sela túrcica;

- osso esfenóide;

- meato acústico externo;

- cavidade orbitária;

- fissura pterigomaxilar;

- maxila;

- mandíbula;

- incisivos centrais e primeiros molares permanentes superiores e inferiores;

- perfil facial tegumentar, iniciando-se acima da glabela e prolongando-se até o contorno anterior do pescoço. 



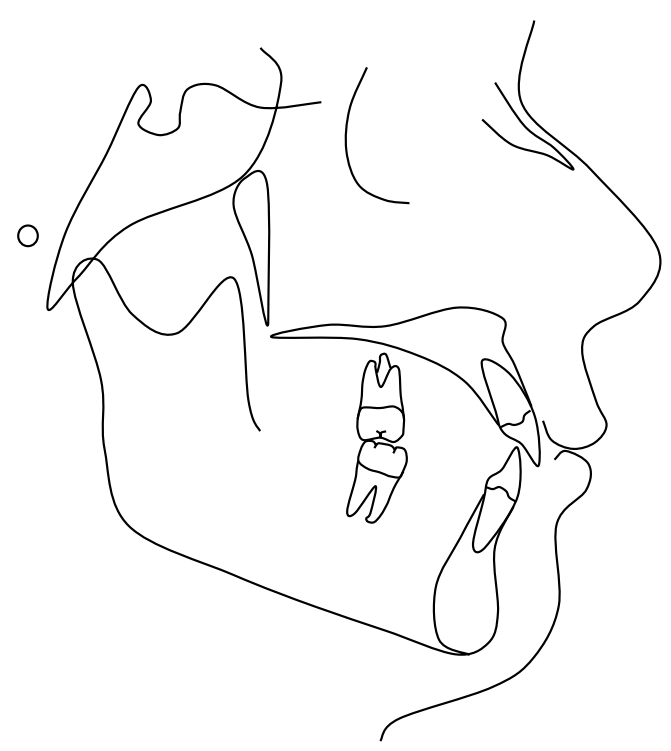

Figura 6 - Delimitação do desenho anatômico.

\subsection{4 - Demarcação dos Pontos Cefalométricos}

Foram demarcados 16 pontos no perfil facial tegumentar e 22 pontos nas estruturas dentoesqueléticas, conforme visualizado na Figura 7.

PONTOS NO TECIDO MOLE

1. Gl' (glabela tegumentar): o ponto mais anterior localizado no perfil mole, acima da órbita;

2. N' (násio-tegumentar): ponto localizado pouco acima da maior concavidade entre o nariz e a fronte:

3. Prn (pronasal): ponto mais anterior do contorno do nariz; 

4. Sn (subnasal): ponto situado na confluência entre a margem inferior da cogumela nasal e o filtro labial;

5. Ma (malar tegumentar): ponto metálico da curvatura do osso malar;

6. Io (infra orbitário tegumentar): ponto metálico na rima orbitária tegumentar

7. Bn (base nasal): ponto metálico na base alar;

8. Sp (ponto subpupilar tegumentar): ponto metálico da região subpupilar tegumentar;

9. A' (ponto A tegumentar): o ponto mais posterior localizado na concavidade do lábio superior;

10. Ls (lábio superior): o ponto localizado na junção pele-mucosa entre o lábio superior e o filtro;

11. Li (lábio inferior): o ponto localizado na junção pele-mucosa entre o lábio inferior e a concavidade do queixo;

12. B' (ponto B tegumentar): o ponto mais posterior da concavidade entre o lábio inferior e o mento;

13. Pog' (pogônio tegumentar): ponto mais anterior do contorno do mento tegumentar;

14. Gn' (Gnátio tegumentar): ponto médio entre o ponto mais anterior e inferior do tecido mole do mento no plano sagital mediano;

15. Me' (mentoniano tegumentar): ponto inferior do contorno do mento tegumentar;

16. Pe' (pescoço mandíbula): ponto onde termina o pescoço e inicia a mandíbula tegumentar. 
PONTOS NOS TECIDOS DUROS

17. N (násio): intersecção da sutura internasal com a sutura frontonasal;

18. Or (orbitário): ponto inferior da margem infra-orbitária;

19. S (sela): localizado no centro da sela túrcica;

20. Po (pório): ponto superior do meato acústico externo;

21. Ba (básio): o ponto inferior da margem anterior do forame magno;

22. Pt (pterigomaxilar): ponto mais superior e posterior, no contorno da fissura pterigomaxilar;

23. ENA (espinha nasal anterior): o limite anterior do assoalho nasal;

24. A (ponto A): ponto mais profundo da concavidade anterior da maxila;

25. AIS (ápice do incisivo superior): a extremidade do ápice do incisivo central superior;

26. BIS (borda do incisivo superior): a extremidade da coroa do incisivo central superior;

27. Is (incisivo superior): ponto anterior, na superfície vestibular do incisivo central superior;

28. Ii (incisivo inferior): ponto anterior, na superfície vestibular da coroa do incisivo central inferior;

29. BII (borda do incisivo inferior): a extremidade da coroa do incisivo central inferior;

30. All (ápice do incisivo inferior): a extremidade do ápice do incisivo central inferior;

31. 6S (cúspide do molar superior): a extremidade da cúspide mesial do primeiro molar superior; 
32. 6l (cúspide do molar inferior): a extremidade da cúspide mesial do primeiro molar inferior;

33. B (ponto B): ponto profundo da concavidade anterior da mandíbula;

34. Pog (pogônio): ponto proeminente do contorno anterior do mento ósseo;

35. Gn (gnátio): ponto projetado no osso basal da mandíbula formado pela bissetriz dos pontos pogônio e mentoniano;

36. Me (mentoniano): ponto inferior do contorno da sínfise mentoniana;

37. Go (gônio): ponto projetado no ângulo da mandíbula formado pela bissetriz das retas dos limites inferior e posterior da mandíbula;

38. Co (condílio): ponto mais superior e posterior do contorno do côndilo.

Os pontos de referência foram demarcados seguindo as especificações de STEINER ${ }^{100}$, em 1953, KROGMAN; SASSOUNI ${ }^{58}$, em 1957, SCHEIDEMAN et al. ${ }^{97}$, em 1980, e por McNAMARA Jr. ${ }^{65}$, em 1984. 





Figura 7 - Pontos de referência do traçado cefalométrico

\subsection{5 - Determinação da Linha Vertical Verdadeira}

O desenho da linha vertical verdadeira nos traçados gerados pelo Dolphin Imaging 9.0 dá-se automaticamente após a marcação dos pontos glabela 

tegumentar e subnasal, pela simples união de ambos. Entretanto, a linha vertical verdadeira é definida como uma linha perpendicular ao plano horizontal determinado pela posição natural da cabeça, passando pelo ponto subnasal ${ }^{42}$, sem referência alguma de sua relação com a glabela tegumentar. Dessa forma, surgiu a necessidade de se garantir que a linha criada pelo programa fosse o mais fiel possível à sua definição.

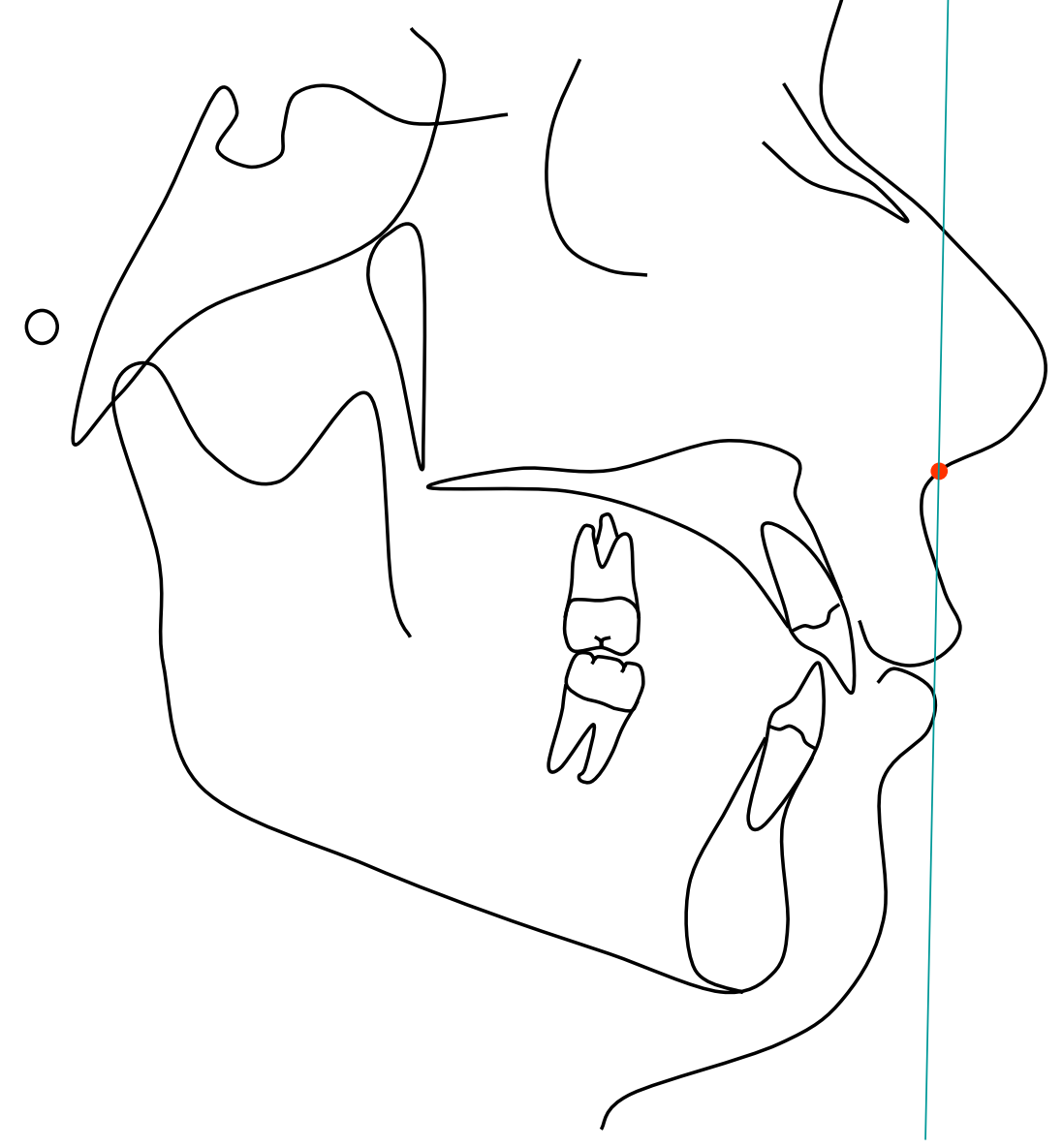

Figura 8 - Linha Vertical Verdadeira 



\subsection{6 - Grandezas Cefalométricas}

Foram utilizadas medidas lineares e angulares.

\section{MEDIDAS DENTOESQUELÉTICAS}

1. Altura posterior da maxila (POM-LVV): ângulo formado entre o Plano Oclusal da Maxila e a Linha Vertical Verdadeira (Figura 9)



Figura 9 - Altura posterior da maxila (ângulo formado pelo plano oclusal da maxila e a Linha Vertical Verdadeira). 

2. IS-POM: ângulo formado pelo Incisivo Superior e o Plano Oclusal da Maxila (Figura 10)

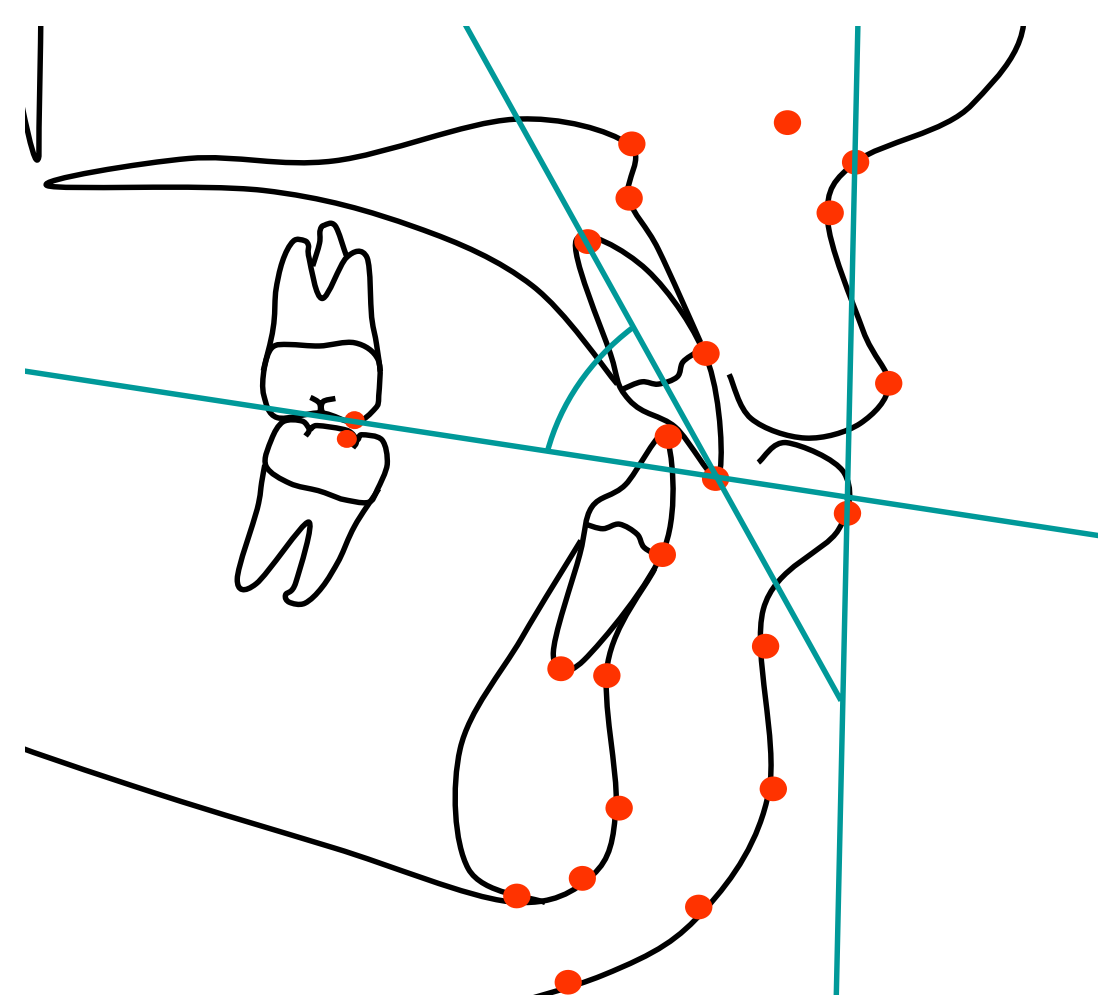

Figura 10 - Ângulo formado pelo incisivo superior e o plano oclusal da maxila. 

3. II-POMd : ângulo formado pelo Incisivo Inferior e o Plano Oclusal da Mandíbula (Figura 11)

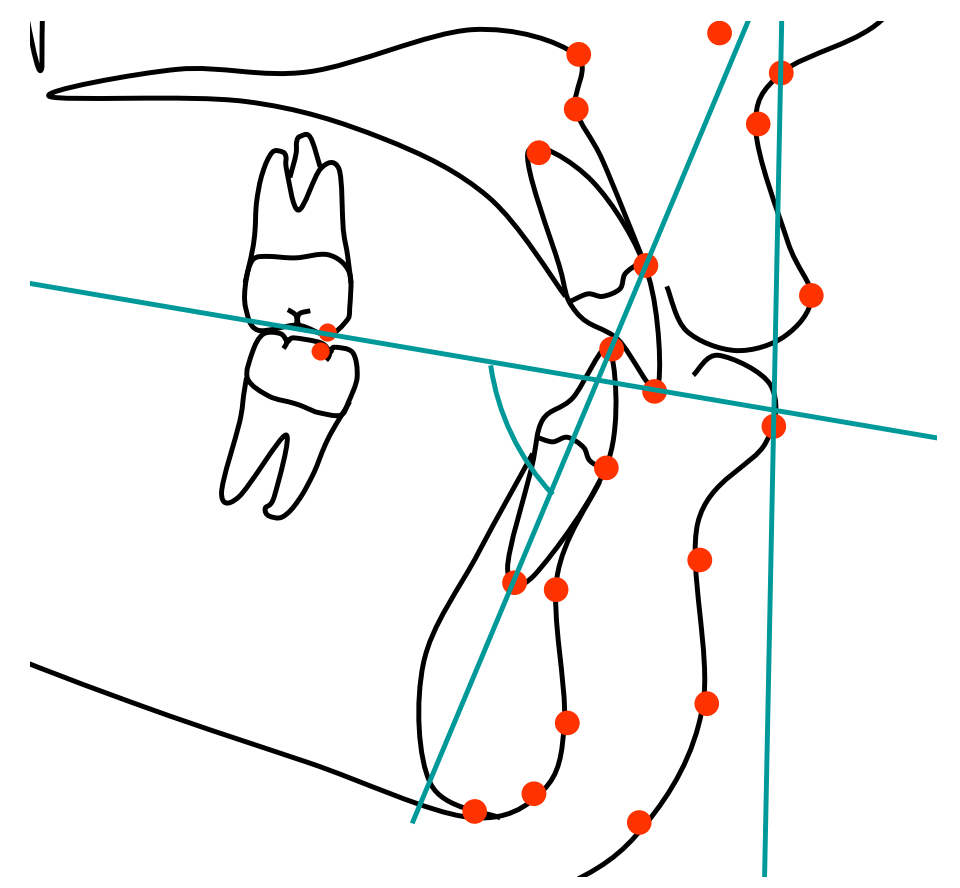

Figura 11 - Ângulo formado pelo incisivo inferior e o plano oclusal da mandíbula.

4. Overjet (BIS-BII): distância horizontal entre o ponto Borda Superior e o ponto Borda do Incisivo Inferior (Figura 12).

5. Overbite (BIS-BII): distância vertical entre a Borda do Incisivo Superior e a Borda do Incisivo Inferior (Figura 12). 



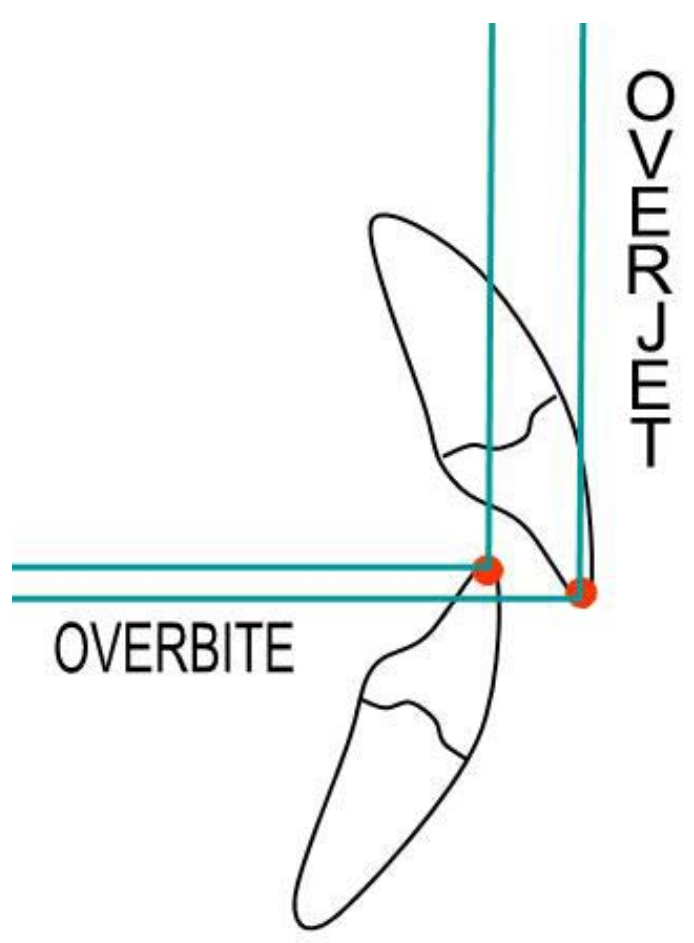

Figura 12 - Overjet e Overbite.

\section{ESTRUTURAS DO TECIDO MOLE}

6. Espessura do lábio superior (Is-Ls): distância entre o ponto do Incisivo Superior e o ponto Lábio Superior.

7. Espessura do lábio inferior (li-Li): distância entre o ponto do Incisivo Inferior e o ponto Lábio Inferior.

8. Espessura do queixo (Pog-Pog'): distância entre o Pogônio e o ponto Pogônio tegumentar.

9. Espessura do mento (Me-Me'): distância entre o ponto Mentoniano e o ponto Mentoniano tegumentar. 



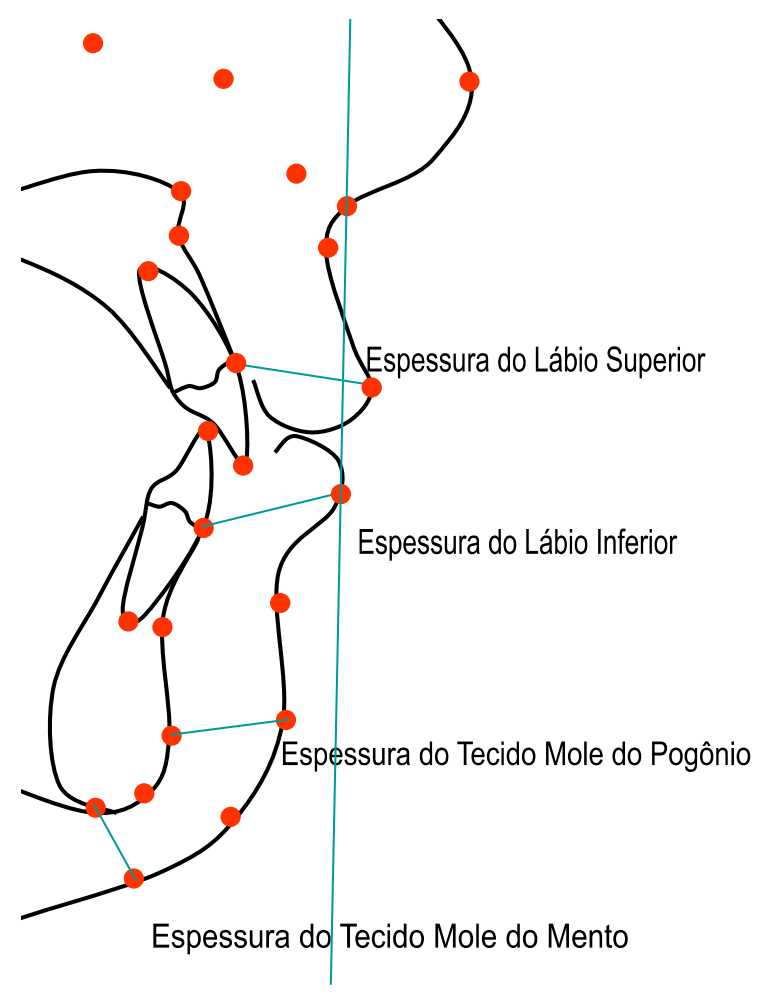

Figura 13 - Espessura do lábio superior, inferior, pogônio e mento. 

10. Ângulo nasolabial (Col-Sn-Ls): ângulo formado pela columela, ponto Subnasal e ponto Lábio Superior (Figura 14).

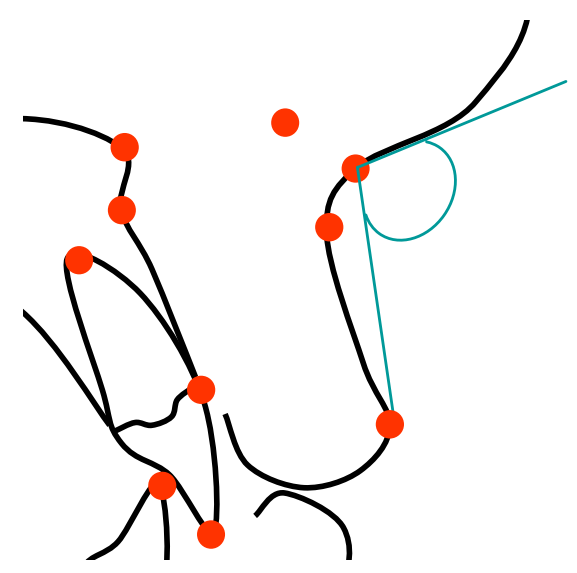

Figura 14 - Ângulo Nasolabial

11. Ângulo do lábio superior (Ls-Sn-LVV): Ângulo formado entre o ponto Lábio Superior, ponto Subnasal e a Linha Vertical Verdadeira (Figura 15).



Figura 15 - Ângulo do Lábio Superior. 

12. Comprimento facial (N'- Me'): distância entre os pontos Násio tegumentar e Mentoniano Tegumentar.

13. Comprimento do lábio superior (Sn-ILS): distância entre o ponto Subnasal e o limite Inferior do Lábio Superior.

14. Gap interlabial (ILS-SLI): distância entre os limites Inferior do Lábio Superior e Superior do Lábio Inferior.

15. Comprimento do lábio inferior (SLI-ME'): distância entre o limite Superior do Lábio Inferior ao ponto Mentoniano tegumentar.

16. Terço inferior da face (Sn-Me'): distância entre os pontos subnasal e Mentoniano tegumentar.

17. Exposição de Incisivo (ILS-BIS): distância entre o limite Inferior do Lábio Superior e a Borda do Incisivo Superior.

18. Comprimento anterior da maxila (Sn-BIS): distância entre o ponto Subnasal e a Borda do Incisivo Superior.

19. Comprimento anterior da mandíbula (BII-Me'): distância entre a Borda do Incisivo Inferior e o ponto Mentoniano tegumentar. 



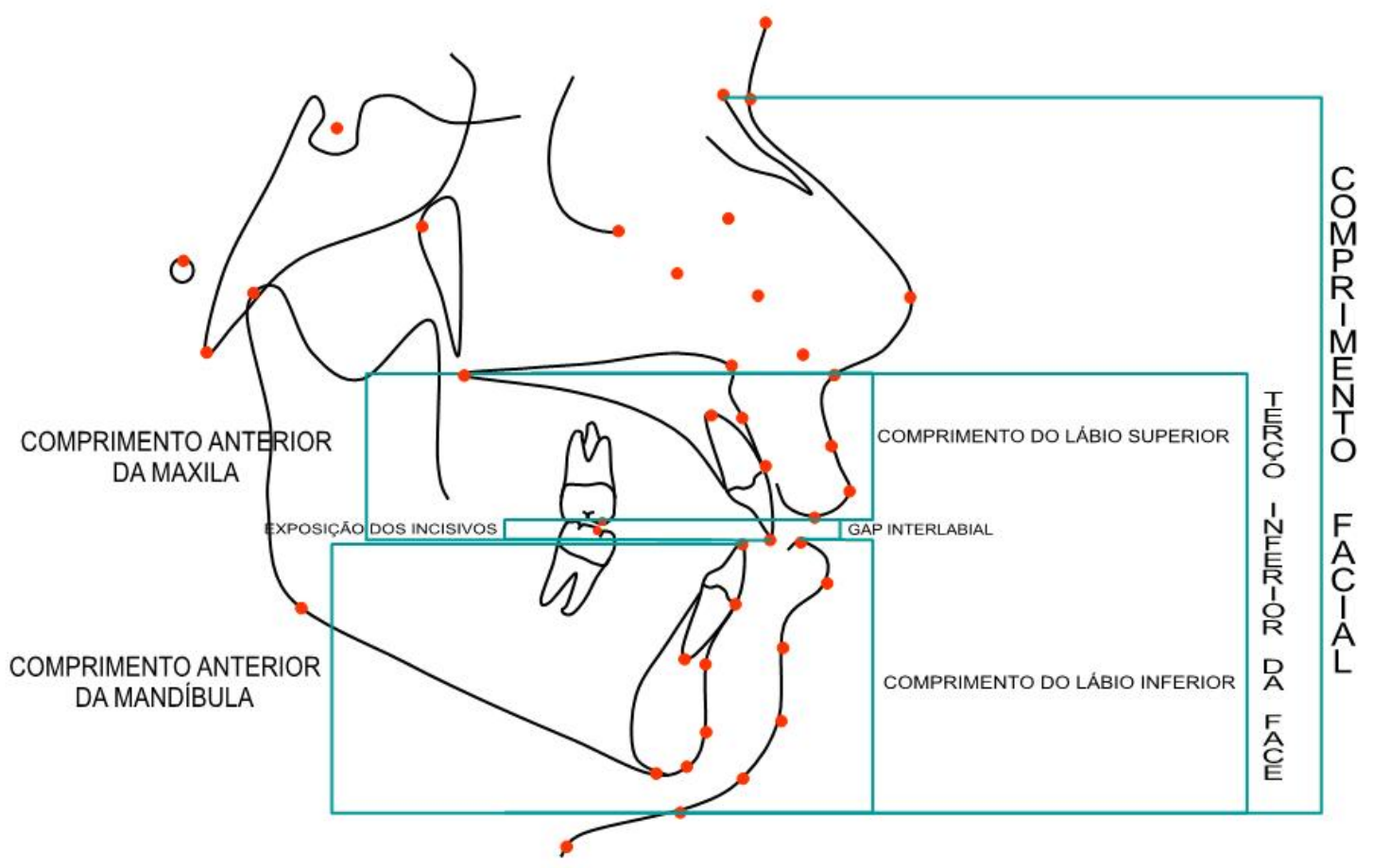

Figura 16 - Comprimento facial.

PROJEÇÕES EM RELAÇÃO À LINHA VERTICAL VERDADEIRA (Figura 17):

20. Gl'- LVV: distância entre o ponto Glabela tegumentar e a linha vertical verdadeira.

21. lo - LVV: distância entre o ponto Infra-orbital tegumentar e a linha vertical verdadeira.

22. Ma-LVV: distância entre o ponto Malar tegumentar e a linha vertical verdadeira.

23. Sp-LVV: distância entre o ponto Subpupilar tegumentar e a linha vertical verdadeira. 

24. Bn-LVV: distância entre o ponto Base nasal e a linha vertical verdadeira.

25. Prn-LVV: distância entre o ponto Pronasal e a linha vertical verdadeira.

26. Sn-LVV: distância entre o ponto Subnasal e a linha vertical verdadeira.

27. A'-LVV: distância entre o ponto $A$ tegumentar e a linha vertical verdadeira.

28. Ls-LVV: distância entre o ponto Lábio superior e a linha vertical verdadeira.

29. BIS-LVV: distância entre o ponto Borda do incisivo superior e a linha vertical verdadeira.

30. BII-LVV: distância entre o ponto Borda do incisivo inferior e a linha vertical verdadeira.

31. Li-LVV: distância entre o ponto Lábio inferior e a linha vertical verdaderia.

32. B'-LVV: distância entre o ponto B tegumentar e a linha vertical verdadeira.

33. Pog'-LVV: distância entre o ponto Pog' tegumentar e a linha vetical verdadeira. 



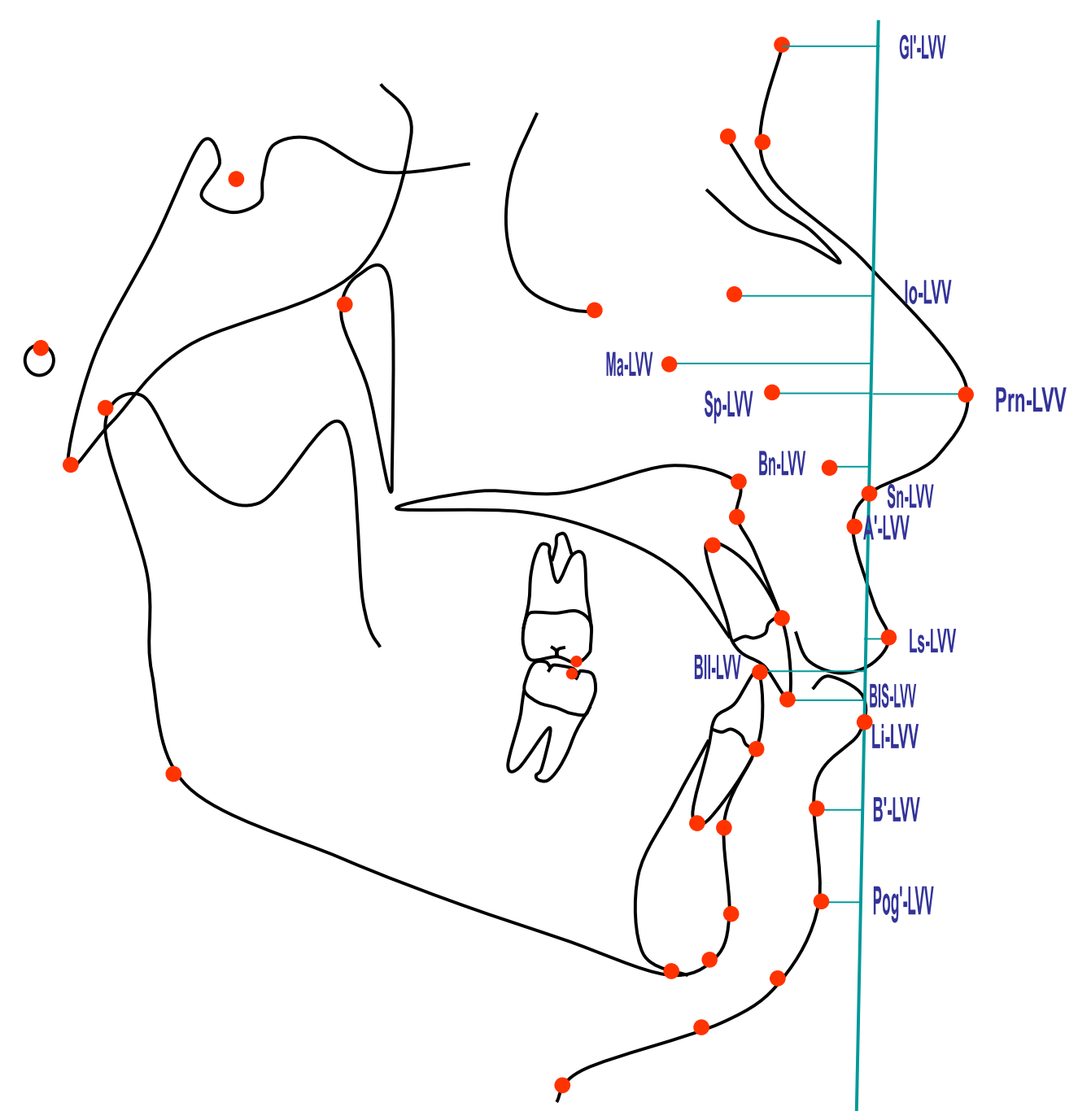

Figura 17 - Projeção dos pontos cefalométricos do tecido mole em relação à Linha Vertical Verdadeira.

\section{3 - Análise Estatística}

Para a avaliação do erro intra-examinador foram realizadas novamente todas as medidas, nas telerradiografias, de todos os pacientes após um intervalo de 15 dias. Determinou-se, desse modo, a diferença entre a primeira e segunda medição de cada telerradiografia. A aplicação da fórmula proposta por DAHLBERG ${ }^{32}$ $\left(\mathrm{Se}^{2}=\right.$ somatória $\left.\mathrm{d}^{2} / 2 \mathrm{n}\right)$ permitiu estimar a ordem de grandeza dos erros casuais. A 

obtenção dos erros sistemáticos procedeu-se pela aplicação do teste t pareado de acordo com BAUMRIND; FRANTZ ${ }^{14}$, GRAVELY; BENZIES ${ }^{46}$, HOUSTON $^{51}$ E RICHARDSON ${ }^{85}$.

Calculou-se a média e o desvio-padrão de todas as medidas avaliadas e comparou-as com o padrão americano proposto por ARNETT et al. ${ }^{10}$ através do teste t paramétrico não pareado para avaliar a existência de diferença estatística significante. Para a realização do teste t utilizou-se a média, o desvio-padrão de cada medida e o número da amostra para homens e mulheres. A fórmula do teste $t$ foi deduzida no programa Microsoft Excel (Microsoft Corporation) para um nível de significância de 0,05 e a probabilidade (p) foi dada pela função "distribuição do teste t" do próprio programa Microsoft Excel (Microsoft Corporation). 

5 - RESULTADOS 



\section{5 - RESULTADOS}

Para estabelecer o erro intra-examinador no momento do traçado cefalométrico, o erro do método analisado, o erro sistemático e o erro casual utilizouse o teste t de student e do erro Dahlberg, respectivamente. Os dados obtidos foram analisados e, quando se apresentaram com diferenças significantes, as variáveis não comprometiam estatisticamente os resultados. Os resultados finais do erro do método podem ser analisados na Tabela 1. 
TABELA 1 - Erro do método da análise cefalométrica do tecido mole utilizando o software Dolphin.

\begin{tabular}{|c|c|c|}
\hline & p (student) & Erro Dalhberg \\
\hline Altura posterior da maxila (POM-LVV) $\left(^{\circ}\right)$ & 0,967 & 1,00 \\
\hline IS-POM( $\left(^{\circ}\right)$ & 0,043 & 2,14 \\
\hline II POMd( $\left.{ }^{\circ}\right)$ & 0,158 & 1,69 \\
\hline Overjet(mm) & 0,870 & 0,50 \\
\hline Overbite (mm) & 0,952 & 0,35 \\
\hline Espessura do lábio superior (mm) & 0,304 & 1,20 \\
\hline Espessura do lábio inferior (mm) & 0,519 & 0,65 \\
\hline Espessura do queixo (Pog-Pog') (mm) & 0,963 & 0,90 \\
\hline Espessura do mento (Me-Me') (mm) & 0,318 & 1,62 \\
\hline Ângulo nasolabial ( ${ }^{\circ}$ ) & 0,598 & 4,74 \\
\hline Ângulo labial $\left({ }^{\circ}\right)$ & 0,340 & 4,47 \\
\hline Comprimento facial (mm) & 0,549 & 1,84 \\
\hline Comprimento do lábio superior (mm) & 0,055 & 0,81 \\
\hline Gap interlabial (mm) & 0,026 & 0,49 \\
\hline Comprimento do lábio inferior (mm) & 0,928 & 1,59 \\
\hline Terço inferior da face (mm) & 0,653 & 1,29 \\
\hline Exposição de incisivo (mm) & 0,033 & 0,30 \\
\hline Comprimento anterior da maxila $(\mathrm{mm})$ & 0,110 & 0,64 \\
\hline Comprimento anterior da mandíbula (mm) & 0,881 & 1,38 \\
\hline Glabela tegumentar (mm) & 0,343 & 0,02 \\
\hline Infra-orbitário tegumentar (mm) & 0,141 & 0,69 \\
\hline Malar tegumentar (mm) & 0,408 & 2,75 \\
\hline Ponto subpupilar tegumentar (mm) & 0,280 & 3,22 \\
\hline Base nasal (mm) & 0,139 & 1,25 \\
\hline Pronasal (mm) & 0,449 & 0,53 \\
\hline Subnasal (mm) & 0,00 & 0,00 \\
\hline Ponto A tegumentar (mm) & 0,69 & 0,95 \\
\hline Lábio superior (mm) & 0,879 & 0,81 \\
\hline Borda do incisivo superior (mm) & 0,964 & 0,90 \\
\hline Borda do incisivo inferior ( $\mathrm{mm}$ ) & 1,000 & 0,91 \\
\hline Lábio inferior (mm) & 0,582 & 1,25 \\
\hline Ponto B tegumentar (mm) & 0,261 & 1,18 \\
\hline Pogônio tegumentar (mm) & 0,622 & 1,31 \\
\hline
\end{tabular}

Após a padronização do método empregado, calculou-se a média e o desvio-padrão das 33 medidas relevantes para a obtenção do padrão brasileiro (feoderma) da análise cefalométrica dos tecidos moles. Nas tabelas seguintes (Tabela 2 a 13) podem-se visualizar a média e o desvio padrão dos brasileiros feodermas, dos americanos e o valor de 'p' resultante da distribuição do teste 't' para um nível de significância de 0,05. 
TABELA 2 - Comparação das medidas dentoesqueléticas entre os sexos feminino e masculino dos feodermas brasileiros.

\begin{tabular}{lrrrrr}
\hline \multicolumn{1}{c}{ Medidas dentoesqueléticas } & \multicolumn{2}{c}{ Feminino } & \multicolumn{3}{c}{ Masculino } \\
& Média & DP & Média & DP & p (t) \\
\hline Altura posterior da maxila (POM-LVV) $\left(^{\circ}\right)$ & 100,79 & 5,79 & 97,68 & 3,5 & 0,051 \\
IS-POM $\left({ }^{\circ}\right)$ & 53,93 & 4,88 & 54,36 & 4,3 & 0,773 \\
II POMd $\left({ }^{\circ}\right)$ & 60,74 & 6,73 & 60,17 & 5,9 & 0,782 \\
Overjet $(\mathrm{mm})$ & 3,22 & 0,64 & 3,94 & 0,9 & $0,006^{*}$ \\
Overbite $(\mathrm{mm})$ & 2,30 & 1,12 & 2,30 & 1,8 & 0,992 \\
\hline
\end{tabular}

TABELA 3 - Comparação das medidas dos tecidos moles entre os sexos feminino e masculino dos feodermas brasileiros.

\begin{tabular}{lccccc}
\hline \multicolumn{1}{c}{ Estruturas do tecido mole } & \multicolumn{3}{c}{ Feminino } & \multicolumn{3}{c}{ Masculino } \\
\hline & Média & DP & Média & DP & p(t) \\
\hline Espessura do lábio superior $(\mathrm{mm})$ & 16,29 & 2,88 & 16,64 & 2,67 & 0,695 \\
Espessura do lábio inferior $(\mathrm{mm})$ & 11,62 & 1,66 & 11,78 & 2,29 & 0,799 \\
Espessura do queixo (Pog-Pog') $(\mathrm{mm})$ & 13,83 & 2,84 & 15,04 & 2,53 & 0,170 \\
Espessura do mento (Me-Me') $(\mathrm{mm})$ & 13,85 & 3,32 & 14,85 & 3,15 & 0,343 \\
Ângulo nasolabial $\left({ }^{\circ}\right)$ & 98,70 & 8,13 & 98,37 & 9,94 & 0,912 \\
Ângulo do lábio superior $\left({ }^{\circ}\right)$ & 14,87 & 9,45 & 12,55 & 8,68 & 0,431 \\
\hline
\end{tabular}

TABELA 4 - Comparação das medidas do comprimento facial entre os sexos feminino e masculino dos feodermas brasileiros.

\begin{tabular}{lrrrrc}
\hline \multicolumn{1}{c}{ Comprimento facial } & \multicolumn{2}{c}{ Feminino } & \multicolumn{2}{c}{ Masculino } & \\
\hline & Média & DP & \multicolumn{1}{c}{ Média } & \multicolumn{1}{c}{ DP } & p(t) \\
\hline Comprimento facial $(\mathrm{mm})$ & 121,90 & 8,56 & 131,0 & 7,95 & $0,001^{*}$ \\
Comprimento do lábio superior (mm) & 22,09 & 2,89 & 23,67 & 3,08 & 0,105 \\
Gap interlabial (mm) & 1,67 & 0,85 & 1,68 & 0,92 & 0,960 \\
Comprimento do lábio inferior (mm) & 47,42 & 4,23 & 50,51 & 4,38 & $0,031^{*}$ \\
Terço inferior da face (mm) & 71,16 & 6,47 & 75,85 & 6,46 & $0,030^{*}$ \\
Exposição de incisivo (mm) & 2,99 & 1,96 & 2,09 & 1,38 & 0,109 \\
Comprimento anterior da maxila (mm) & 25,10 & 3,66 & 25,77 & 3,21 & 0,549 \\
Comprimento anterior da mandíbula (mm) & 48,36 & 4,02 & 52,37 & 3,70 & $0,003^{*}$ \\
\hline
\end{tabular}


TABELA 5 - Comparação das medidas de projeção em relação à LVV entre os sexos feminino e masculino dos feodermas brasileiros.

\begin{tabular}{llllll}
\hline \multicolumn{1}{c}{ Projeção em relação à LVV } & \multicolumn{2}{c}{ Feminino } & \multicolumn{2}{c}{ Masculino } & \\
& Média & DP & Média & DP & p(t) \\
\hline Glabela tegumentar (mm) & $-7,67$ & 1,93 & $-8,48$ & 0,04 & 0,235 \\
Infra-orbitário tegumentar (mm) & $-20,41$ & 2,50 & $-23,18$ & 2,37 & $0,001^{*}$ \\
Malar tegumentar (mm) & $-26,33$ & 3,89 & $-28,41$ & 5,36 & 0,172 \\
Ponto subpupilar tegumentar & $-15,41$ & 2,77 & $-19,13$ & 4,74 & $0,005^{*}$ \\
(mm) & & & & & \\
Base nasal (mm) & $-10,78$ & 2,59 & $-13,43$ & 2,54 & $0,003^{*}$ \\
Pronasal (mm) & 14,60 & 1,74 & 16,60 & 1,93 & $0,002^{*}$ \\
Subnasal (mm) & 0,00 & 0,00 & 0,00 & 0,00 & 0,00 \\
Ponto A tegumentar (mm) & 0,57 & 2,22 & 0,19 & 1,36 & 0,524 \\
Lábio superior (mm) & 5,63 & 2,87 & 5,33 & 2,38 & 0,722 \\
Borda do incisivo superior (mm) & $-9,41$ & 3,94 & $-10,51$ & 2,27 & 0,297 \\
Borda do incisivo inferior (mm) & $-12,62$ & 4,07 & $-14,48$ & 2,86 & 0,107 \\
Lábio inferior (mm) & 2,14 & 4,07 & 1,71 & 3,65 & 0,731 \\
Ponto B tegumentar (mm) & 5,93 & 5,12 & $-8,16$ & 4,66 & 0,164 \\
Pongônio tegumentar (mm) & $-6,83500$ & 5,54752 & $-6,55$ & 5,86 & 0,878 \\
\hline * A medida Subnasal tem o valor da medida 0 porque a LVV passa pelo ponto Subnasal.
\end{tabular}

* A medida Subnasal tem o valor da medida 0 porque a LVV passa pelo ponto Subnasal. 
TABELA 6 - Comparação das medidas dentoesqueléticas dos feodermas brasileiros da análise cefalométrica do tecido mole com o padrão americano para o sexo feminino.

\begin{tabular}{lrrrrc}
\hline \multicolumn{1}{c}{ Medidas dentoesqueléticas } & \multicolumn{3}{c}{ Brasileiras } & \multicolumn{3}{c}{ Americanas } \\
& Média & DP & Média & DP & $\mathbf{p ~ ( t )}$ \\
\hline Altura posterior da maxila $\left(\right.$ POM-LVV) $\left(^{\circ}\right)$ & 100,79 & 5,79 & 95,6 & 1,8 & $\mathbf{0 , 0 0 0 1 ^ { * }}$ \\
IS-POM $\left(^{\circ}\right)$ & 53,93 & 4,88 & 56,8 & 2,5 & $\mathbf{0 , 0 1 2 8}^{*}$ \\
II POMd $\left({ }^{\circ}\right)$ & 60,74 & 6,73 & 64,3 & 3,2 & $\mathbf{0 , 0 2 1 7 ^ { * }}$ \\
Overjet $(\mathrm{mm})$ & 3,22 & 0,64 & 3,2 & 0,4 & $\mathbf{0 , 8 9 6 8}$ \\
Overbite $(\mathrm{mm})$ & 2,30 & 1,12 & 3,2 & 0,7 & $\mathbf{0 , 0 0 1 6 ^ { * }}$ \\
\hline
\end{tabular}

TABELA 7 - Comparação das medidas dentoesqueléticas dos feodermas brasileiros da análise cefalométrica do tecido mole com o padrão americano para o sexo masculino.

\begin{tabular}{lclllc}
\hline \multicolumn{1}{c}{ Medidas dentoesqueléticas } & \multicolumn{3}{c}{ Brasileiros } & \multicolumn{3}{c}{ Americanos } \\
\hline & Média & DP & Média & DP & $\mathbf{p ~ ( t )}$ \\
\hline Altura posterior da maxila (POM-LVV) $\left(^{\circ}\right)$ & 97,68 & 3,50 & 95 & 1,4 & $\mathbf{0 , 0 0 3 1 ^ { * }}$ \\
IS-POM $\left(^{\circ}\right)$ & 54,36 & 4,38 & 57,8 & 3 & $\mathbf{0 , 0 0 6 7}^{*}$ \\
II POMd $\left({ }^{\circ}\right)$ & 60,17 & 5,93 & 64 & 4 & $\mathbf{0 , 0 2 2 7 ^ { * }}$ \\
Overjet $(\mathrm{mm})$ & 3,94 & 0,91 & 3,2 & 0,6 & $\mathbf{0 , 0 0 4 5 ^ { * }}$ \\
Overbite $(\mathrm{mm})$ & 2,30 & 1,83 & 3,2 & 0,7 & $\mathbf{0 , 0 4 7 9}$ \\
\hline
\end{tabular}


TABELA 8 - Comparação das medidas dos tecidos moles dos feodermas brasileiros da análise cefalométrica do tecido mole com o padrão americano para o sexo feminino.

\begin{tabular}{|c|c|c|c|c|c|}
\hline \multirow{2}{*}{ Estruturas do tecido mole } & \multicolumn{2}{|c|}{ Brasileiras } & \multicolumn{3}{|c|}{ Americanas } \\
\hline & Média & DP & Média & DP & $p(t)$ \\
\hline Espessura do lábio superior (mm) & 16,29 & 2,88 & 12,6 & 1,8 & $0,0000^{*}$ \\
\hline Espessura do lábio inferior (mm) & 11,62 & 1,66 & 13,6 & 1,4 & $0,0001^{*}$ \\
\hline Espessura do queixo (Pog-Pog') (mm) & 13,83 & 2,84 & 11,8 & 1,5 & $0,0031^{\star}$ \\
\hline Espessura do mento (Me-Me') (mm) & 13,85 & 3,32 & 7,4 & 1,6 & $0,0000^{*}$ \\
\hline Ângulo nasolabial $\left({ }^{\circ}\right)$ & 98,70 & 8,13 & 104 & 6,8 & $0,0203^{*}$ \\
\hline Ângulo do lábio superior $\left({ }^{\circ}\right)$ & 14,87 & 9,45 & 12,1 & 5,1 & 0,2096 \\
\hline
\end{tabular}

TABELA 9 - Comparação das medidas dos tecidos moles dos feodermas brasileiros da análise cefalométrica do tecido mole com o padrão americano para o sexo masculino.

\begin{tabular}{lllccc}
\hline \multicolumn{1}{c}{ Estruturas do tecido mole } & \multicolumn{2}{c}{ Brasileiros } & \multicolumn{2}{c}{ Americanos } & \\
\hline & Média & DP & Média & DP & $\mathbf{p ( t )}$ \\
\hline Espessura do lábio superior $(\mathrm{mm})$ & 16,64 & 2,67 & 14,8 & 1,4 & $\mathbf{0 , 0 1 0 0 ^ { * }}$ \\
Espessura do lábio inferior $(\mathrm{mm})$ & 11,78 & 2,29 & 15,1 & 1,2 & $\mathbf{0 , 0 0 0 0 ^ { * }}$ \\
Espessura do queixo (Pog-Pog') $(\mathrm{mm})$ & 15,04 & 2,53 & 13,5 & 2,3 & $\mathbf{0 , 0 5 4 4}$ \\
Espessura do mento $\left(\mathrm{Me}-\mathrm{Me}^{\prime}\right)(\mathrm{mm})$ & 14,85 & 3,15 & 8,8 & 1,3 & $\mathbf{0 , 0 0 0 0 ^ { * }}$ \\
Ângulo nasolabial $\left({ }^{\circ}\right)$ & 98,37 & 9,94 & 106 & 7,7 & $\mathbf{0 , 0 1 0 8 ^ { * }}$ \\
Ângulo do lábio superior $\left({ }^{\circ}\right)$ & 12,55 & 8,68 & 8,3 & 5,4 & $\mathbf{0 , 0 7 3 0}$ \\
\hline
\end{tabular}


TABELA 10 - Comparação das medidas do comprimento facial dos feodermas brasileiros da análise cefalométrica do tecido mole com o padrão americano para o sexo feminino.

\begin{tabular}{lccccc}
\hline \multicolumn{1}{c}{ Comprimento facial } & \multicolumn{7}{c}{ Brasileiras } & \multicolumn{3}{c}{ Americanas } & \\
\hline & Média & DP & Média & DP & p(t) \\
\hline Comprimento facial $(\mathrm{mm})$ & 121,90 & 8,56 & 125 & 4,7 & $\mathbf{0 , 1 2 4 2}$ \\
Comprimento do lábio superior (mm) & 22,09 & 2,89 & 21 & 1,9 & $\mathbf{0 , 1 3 1 9}$ \\
Gap interlabial (mm) & 1,67 & 0,85 & 3,3 & 1,3 & $\mathbf{0 , 0 0 0 0 ^ { * }}$ \\
Comprimento do lábio inferior (mm) & 47,42 & 4,23 & 46,9 & 2,3 & $\mathbf{0 , 5 9 6 4}$ \\
Terço inferior da face (mm) & 71,16 & 6,47 & 71,1 & 3,5 & $\mathbf{0 , 9 6 8 0}$ \\
Exposição de incisivo (mm) & 2,99 & 1,96 & 4,7 & 1,6 & $\mathbf{0 , 0 0 2 1 ^ { * }}$ \\
Comprimento anterior da maxila (mm) & 25,10 & 3,66 & 25,7 & 2,1 & $\mathbf{0 , 4 8 7 4}$ \\
Comprimento anterior da mandíbula $(\mathrm{mm})$ & 48,36 & 4,02 & 48,6 & 2,4 & $\mathbf{0 , 8 0 2 1}$ \\
\hline
\end{tabular}


TABELA 11 - Comparação das medidas do comprimento facial dos feodermas brasileiros da análise cefalométrica do tecido mole com o padrão americano para o sexo masculino.

\begin{tabular}{|c|c|c|c|c|c|}
\hline \multirow[t]{2}{*}{ Comprimento facial } & \multicolumn{2}{|c|}{ Brasileiros } & \multicolumn{2}{|c|}{ Americanos } & \multirow[b]{2}{*}{$p(t)$} \\
\hline & Média & DP & Média & DP & \\
\hline Comprimento facial (mm) & 131,0 & 7,95 & 138 & 6,5 & $0,0051^{*}$ \\
\hline Comprimento do lábio superior (mm) & 23,67 & 3,08 & 24,4 & 2,5 & 0,4232 \\
\hline Gap interlabial (mm) & 1,68 & 0,92 & 2,4 & 1,1 & $0,0346^{*}$ \\
\hline Comprimento do lábio inferior (mm) & 50,51 & 4,38 & 54,3 & 2,4 & $0,0017^{*}$ \\
\hline Terço inferior da face $(\mathrm{mm})$ & 75,85 & 6,46 & 81,1 & 4,7 & $0,0060^{*}$ \\
\hline Exposição de incisivo (mm) & 2,09 & 1,38 & 3,9 & 1,2 & $0,0001^{*}$ \\
\hline Comprimento anterior da maxila $(\mathrm{mm})$ & 25,77 & 3,21 & 28,4 & 3,2 & $0,0146^{*}$ \\
\hline Comprimento anterior da mandíbula $(\mathrm{mm})$ & 52,37 & 3,70 & 56 & 3 & $0,0017^{*}$ \\
\hline
\end{tabular}

TABELA 12 - Comparação das medidas da projeção à LVV dos feodermas brasileiros da análise cefalométrica do tecido mole com o padrão americano para o sexo feminino.

\begin{tabular}{|c|c|c|c|c|c|}
\hline \multirow[t]{2}{*}{ Projeção em relação à LVV } & \multicolumn{2}{|c|}{ Brasileiras } & \multicolumn{2}{|c|}{ Americanas } & \multirow[b]{2}{*}{$p(t)$} \\
\hline & Média & DP & Média & DP & \\
\hline Glabela tegumentar (mm) & $-7,67$ & 1,93 & $-8,5$ & 2,4 & 0,4070 \\
\hline Infra-orbitário tegumentar (mm) & $-20,41$ & 2,50 & $-18,7$ & 2 & $0,0134^{*}$ \\
\hline Malar tegumentar (mm) & $-26,33$ & 3,89 & $-20,6$ & 2,4 & $0,0000^{*}$ \\
\hline $\begin{array}{l}\text { Ponto subpupilar tegumentar } \\
\text { (mm) }\end{array}$ & $-15,41$ & 2,77 & $-14,8$ & 2,1 & 0,4040 \\
\hline Base nasal (mm) & $-10,78$ & 2,59 & $-12,9$ & 1,1 & $0,0005^{*}$ \\
\hline Pronasal (mm) & 14,60 & 1,74 & 16 & 1,4 & $0,0040^{*}$ \\
\hline Subnasal (mm) & 0,00 & 0,00 & 0 & 0 & 0,00 \\
\hline Ponto A tegumentar (mm) & 0,57 & 2,22 & $-0,1$ & 1 & 0,1764 \\
\hline Lábio superior (mm) & 5,63 & 2,87 & 3,7 & 1,2 & $0,0034^{*}$ \\
\hline Borda do incisivo superior (mm) & $-9,41$ & 3,94 & $-9,2$ & 2,2 & 0,8193 \\
\hline Borda do incisivo inferior (mm) & $-12,62$ & 4,07 & $-12,4$ & 2,2 & 0,8193 \\
\hline Lábio inferior (mm) & 2,14 & 4,07 & 1,9 & 1,4 & 0,7848 \\
\hline Ponto B tegumentar (mm) & 5,93 & 5,12 & $-5,3$ & 1,5 & 0,5537 \\
\hline Pogônio tegumentar (mm) & $-6,83500$ & 5,54752 & $-2,6$ & 1,9 & $0,0007^{*}$ \\
\hline
\end{tabular}

${ }^{*}$ A medida Subnasal tem o valor da medida 0 porque a LVV passa pelo ponto Subnasal. 
TABELA 13 - Comparação das medidas da projeção à LVV dos feodermas brasileiros da análise cefalométrica do tecido mole com o padrão americano para o sexo masculino.

\begin{tabular}{lccccc}
\hline \multicolumn{1}{c}{ Projeção em relação à LVV } & \multicolumn{3}{c}{ Brasileiros } & \multicolumn{3}{c}{ Americanos } \\
\hline & Média & DP & Média & DP & $\mathbf{p ( t )}$ \\
\hline Glabela tegumentar (mm) & $-8,48$ & 0,04 & -8 & 2,5 & $\mathbf{0 , 4 0 4 3}$ \\
Infra-orbitário tegumentar (mm) & $-23,18$ & 2,37 & $-22,4$ & 2,7 & $\mathbf{0 , 3 4 2 6}$ \\
Malar tegumentar (mm) & $-28,41$ & 5,36 & $-25,2$ & 4 & $\mathbf{0 , 0 4 0 0}$ \\
Ponto subpupilar tegumentar (mm) & $-19,13$ & 4,74 & $-18,4$ & 1,9 & $\mathbf{0 , 5 2 7 3}$ \\
Base nasal (mm) & $-13,43$ & 2,54 & -15 & 1,7 & $\mathbf{0 , 0 2 8 5}$ \\
Pronasal (mm) & 16,60 & 1,93 & 17 & 1,7 & $\mathbf{0 , 4 9 5 7}$ \\
Subnasal (mm) & 0,00 & 0,00 & 0 & 0 & 0,00 \\
Ponto A tegumentar (mm) & 0,19 & 1,36 & $-0,3$ & 1 & $\mathbf{0 , 2 0 5 7}$ \\
Lábio superior (mm) & 5,33 & 2,38 & 3,3 & 1,7 & $\mathbf{0 , 0 0 4 0}$ \\
Borda do incisivo superior (mm) & $-10,51$ & 2,27 & $-12,1$ & 1,8 & $\mathbf{0 , 0 1 9 6}$ \\
Borda do incisivo inferior (mm) & $-14,48$ & 2,86 & $-15,4$ & 1,9 & $\mathbf{0 , 2 4 4 5}$ \\
Lábio inferior (mm) & 1,71 & 3,65 & 1 & 2,2 & $\mathbf{0 , 4 6 6 6}$ \\
Ponto B tegumentar (mm) & $-8,16$ & 4,66 & $-7,1$ & 1,6 & $\mathbf{0 , 3 4 4 6}$ \\
Pogônio tegumentar (mm) & $-6,55$ & 5,86 & $-3,5$ & 1,8 & $\mathbf{0 , 0 3 2 5}$ \\
\hline * A medida Subnasal tem o valor da medida 0 porque a LVV passa pelo ponto & Subnasal.
\end{tabular}



6 - DISCUSSÃO 



\section{6 - DISCUSSÃO}

No intuito de abordar as dificuldades desta pesquisa e favorecer a interpretação dos resultados, serão discutidas as características da amostra, as considerações da metodologia, a relevância dos resultados e, finalmente, algumas considerações clínicas. Entretanto, não ocorrerá comparação com outros estudos com sujeitos feodermas por serem inexistentes na literatura disponível.

\section{1 - Características da Amostra}

Devem-se considerar problemas metodológicos, como tamanho da amostra, existentes em alguns relatos de modelos cefalométricos em indivíduos melanodermas. O estudo de COTTON et al. ${ }^{29}$ foi baseado em apenas 20 indivíduos. ALTEMUS $^{3}$ selecionou 80 indivíduos, de um grupo de 3289, com as melhores relações oclusais. KOWALSKI et al. ${ }^{57}$, por outro lado, estudou uma amostra considerável de 244 indivíduos. As amostras dos feodermas e leucodermas tiveram seus valores agrupados por sexo, sabendo-se da existência de diferenças nas dimensões cefalométricas entre homens e mulheres. O presente estudo utilizou uma amostra de 39 adultos brasileiros feodermas, com média de idade 22,5, sendo 20 do sexo feminino, com média de idade 21,4 , e 19 do sexo masculino, com idade média de 23,63 .

Para a obtenção da amostra foram selecionados, de ambos os sexos, um grupo de indivíduos feodermas. A subdivisão por grupo racial, sexo e faixa etária entre 18 e 35 anos selecionados nesta pesquisa obteve apoio nos estudos de HUANG; TAYLOR; DASANAYAKE ${ }^{52}$, ARNETT et al. ${ }^{10}$, SANT'ANA ${ }^{94}$, os quais enfatizaram que a cefalometria deve considerar sexo, grupo étnico e idade específicos. A preocupação em se determinar a faixa de idade reside no fato de assegurar que todos os indivíduos da amostra, ao serem submetidos à análise cefalométrica, estivessem com completa maturação esquelética ${ }^{27}$. 
Foi requisito da presente pesquisa uma oclusão dentária com relações normais de molares, sem a presença de mordida profunda, mordida aberta, rotações ou apinhamentos dentários significativos. Foi necessária a presença de todos os dentes permanentes e em oclusão, exceto os terceiros molares. Esse critério representou a maior dificuldade na seleção dos pacientes devido à perda dos primeiros molares permanentes por cárie.

Os critérios para a seleção dos indivíduos dos diferentes estudos variam entre os relatos disponíveis. A maior parte deles utilizou modelos para oclusão, tais como Classe I de Angle, enquanto outros, não ${ }^{57,84}$. Alguns estudos realizaram a seleção de acordo com o alinhamento ideal e presença de todos os dentes permanentes $^{3,10}$ enquanto outros exigiam apenas Classe I de Angle e não especificaram se a mordida aberta, mordida profunda ou outras condições anormais foram excluídas ${ }^{28,42}$. Outros atribuíram em seus estudos apenas o perfil facial agradável, descartando a presença de más oclusões ${ }^{24,84}$.

A amostra desta pesquisa consistiu de indivíduos feodermas com características faciais agradáveis, dentro de um conceito inevitavelmente subjetivo.

Outro aspecto importante é a origem dos feodermas brasileiros, resultado da miscigenação de leucodermas e feodermas, sendo esses indivíduos pertencentes a diversas origens geográficas, (que na discussão dos resultados serão comparados a alguns estudos realizados em indivíduos melanodermas e leucodermas) ${ }^{13,28,33,41}$.

No Brasil, muito particularmente devido à experiência colonial lusitana, não houve segregação de grupos. A miscigenação entre o colonizador português, o indígena e o negro resultou na formação, desde os primeiros tempos da história, de uma população diversificada, sendo o produto de cruzamento de branco-negro, branco-índio, negro-índio parcela ponderável da população brasileira ${ }^{38}$. Cada um dos três grupos básicos (índio, branco e negro) está longe de representar uma etnia pura. Desse modo, torna-se importante estudar as características da população brasileira, analisando os aspectos somáticos respectivos.

As análises cefalométricas, com aplicação ortodôntica ou cirúrgica, desenvolvidas para indivíduos leucodermas têm-se mostrado inadequadas para outras etnias. Assim sendo, é incontestável que pacientes pertencentes a diferentes 
grupos raciais devem ser diagnosticados e tratados de acordo com padrões cefalométricos específicos ${ }^{96}$, levando-se em consideração a miscigenação, conforme ressalta DRUMMOND ${ }^{37}$ e PINZAN $^{80}$. PINZAN ${ }^{80}$ e OKUIAMA ${ }^{75}$ ainda acrescentam que a análise cefalométrica deve ser personalizada, comparando-se as medidas de cada paciente com o padrão cefalométrico estabelecido de forma a respeitar as características individuais.

Portanto, são inexistem informações científicas disponíveis sobre as características cefalométricas do feoderma brasileiro. A ascensão econômica, social, política e cultural do feoderma no nosso país tem proporcionado uma maior procura dos pacientes desse tipo racial ao tratamento ortodôntico e à cirurgia ortognática, aos quais deve ser atribuído um tratamento específico.

\section{2 - Considerações da Metodologia}

Para a realização do presente estudo foi utilizada a análise cefalométrica dos tecidos mole, desenvolvida por ARNETT et al. ${ }^{10}$, pouco utilizada na maioria dos trabalhos devido à sua recente publicação. Essa análise tem sido considerada mais confiável para a realização dos planejamentos ortodônticos e cirúrgicos. No entanto,


diferentes com outras análises. Todos os estudos, mesmo com análises diferentes, demonstraram medidas faciais distintas para cada etnia, o que justifica a continuidade de estudos nesta área. A análise utilizada neste trabalho, proposta por ARNETT et al. ${ }^{10}$, também foi seguida por SANT'ANA ${ }^{94}$ que avaliou leucodermas brasileiros. ARNETT et al. ${ }^{10}$, desenvolveram essa análise ciente das dificuldades apresentadas pelos profissionais em questão. Preocupado em padronizar uma forma precisa da análise facial, criou um protocolo real de planejamento e tratamento ortodôntico e cirúrgico para os pacientes com deformidades esqueléticas.

As várias análises descritas na literatura apresentam diferentes linhas de referência para que sejam detectadas as alterações da face. A "Análise 
Cefalométrica dos Tecidos Moles" utiliza a linha vertical verdadeira. Essa linha passa pelo ponto subnasal e fica perpendicular à posição natural da cabeça. Nesse caso as medidas em relação a essa linha, dependem de uma tomada radiográfica que respeite a posição natural da cabeça.

Embora a determinação da LVV esteja presente neste trabalho, o software utilizado determina automaticamente essa linha, além de corrigir a posição da cabeça caso a tomada radiográfica esteja errada. Assim, esta pesquisa teve a determinação da LVV padronizada, eliminando a possibilidade de erro casual do examinador.

A análise cefalométrica computadorizada para o diagnóstico e planejamento do tratamento das deformidades dentofaciais vêm-se tornando cada vez mais um recurso de análise tridmensional da face.

Com o auxílio de um software de planejamento cefalométrico, Dolphin Imaging 9.0, o mesmo utilizado por Arnett e com grandezas numéricas por ele padronizadas, tornou-se muito simples planejar um tratamento ortodôntico ou uma cirurgia ortognática e diagnosticar todos os defeitos dentoesqueléticos e de perfil facial utilizando como valor-padrão os números de leucodermas norte-americanos ou de qualquer outro valor de normalidade a ele adicionado.

Muitos estudos que comparam modelos estatísticos em melanodermas e leucodermas utilizam os valores médios para indivíduos leucodermas desenvolvidos por pesquisadores diferentes, os quais podem ter utilizado definições de pontos e técnicas de medidas diferentes. Dessa forma, os dois conjuntos de resultados podem não ser diretamente comparáveis.

BAUMRIND; FRANTZ ${ }^{14}$ avaliaram que o erro médio de identificação de pontos de reparo pode ser de 0,37 a 3,75mm, dependendo do ponto de reparo em particular, e que o erro pode ser de 0,43 a $0,86 \mathrm{~mm}$ e de $0,62^{\circ}$ a $3,54^{\circ}$ para as medidas lineares e angulares, respectivamente, dependendo da medida. No presente estudo o teste estatístico, para avaliar o erro do método, não demonstrou diferença entre as medições realizadas em tempos diferentes. (Tabela1) 


\section{3 - Discussão dos resultados}

\subsection{1 - Comparação entre os sexos feminino e masculino}

Considerando a importância em se individualizar o planejamento ortodôntico, a amostra de feodermas teve as suas medidas comparadas entre os sexo feminino e masculino.

Dentre as medidas dentoesqueléticas, observou-se diferença estatística para o overjet. O sexo masculino apresentou maior overjet, no entanto a diferença entre as médias foi inferior a $1 \mathrm{~mm}$. Essa característica também foi observada nos melanodermas do sexo masculino, no trabalho de CONNOR; MOSHIRI ${ }^{28}$.

Os indivíduos de ambos os sexos não apresentaram diferença entre as medidas de tecido mole.

As medidas Comprimento Facial, Comprimento do Lábio Inferior, Terço Inferior da Face e Comprimento da Mandíbula sempre foram maiores nos homens e concentrada no terço inferior mais especificamente na mandíbula. Resultados também observados para os melanodermas do sexo masculino nos trabalhos de MORAES $^{69}$, UCHYAMA ${ }^{107}$, DANDAJENA; CHUNG; NANDA ${ }^{33}$ e FLYNN; AMBROGIO; ZEICHNER ${ }^{41}$

Dentre as medidas em relação à LVV, encontrou-se diferença entre Infraorbitário Tegumentar, Ponto Subpupilar Tegumentar, Base Nasal e Pronasal. Essas medidas sempre foram maiores nos homens. Desse modo, o terço médio da face e a maxila apresentaram-se mais projetada para anterior nos feodermas do sexo masculino. Fato também encontrado em estudos para os melanodermas do sexo masculino ${ }^{13,69,71}$. 


\subsection{2 - Medidas dentoesqueléticas}

Atualmente, as análises utilizadas para o diagnóstico e o plano de tratamento ortodôntico evidenciam a importância do perfil facial. No entanto, desde as primeiras análises cefalométricas, as características esqueléticas e dentárias exercem grande influência no planejamento de ortodontistas e cirurgiões bucomaxilofaciais $^{87,90,100}$.

A análise utilizada neste estudo, embora denominada de "Análise Cefalométrica de Tecidos Moles", também avalia as características dentoesqueléticas do paciente ${ }^{10}$.

A altura posterior da maxila é a única medida dentoesquelética avaliada em relação à Linha Vertical Verdadeira. Com base no plano oclusal da maxila, observou-se a altura posterior da maxila diminuída nos feodermas brasileiros em ambos os sexos (Tabelas 6 e 7). Embora outros estudos não evidenciem especificamente a altura posterior da maxila, os melanodermas apresentam, em geral, a altura facial posterior aumentada em relação aos leucodermas ${ }^{13,33,70}$. Essa diferença nos resultados pode ser conseqüência da miscigenação racial que levou a uma maxila mais curta, influenciada pela característica dos leucodermas. No entanto, as características de altura facial serão discutidas com maior propriedade com a comparação entre as medidas de comprimento facial.

A posição dos incisivos compreende outro fator relevante, pois os lábios refletem a suas posições.

Os incisivos se apresentaram mais inclinados para vestibular nos feodermas brasileiros em ambos os sexos (Tabelas 6 e 7). Esses resultados acompanham outros estudos que demonstram maior vestibularização dos incisivos em melanodermas $3,13,16,37,42,67$. No estudo realizado por SANT'ANA ${ }^{94}$, a amostra de leucodermas brasileiros de ambos os gêneros também apresentou maior vestibularização dos incisivos em relação aos americanos. A vestibularização dos incisivos é comumente corrigida em casos de extração seguida de retração dos 
dentes anteriores. O conhecimento do fato de que os feodermas apresentam maior vestibularização dos incisivos auxilia o planejamento ortodôntico. Nesses pacientes as extrações podem ser evitadas com maior freqüência que nos leucodermas, conforme se observou nos resultados desta pesquisa.

A relação interincisivos também foi avaliada pelas medidas de overjet e overbite. No sexo feminino, as amostras apresentaram valores de overjet estatisticamente semelhantes. Porém, os valores para overbite foram diferentes, fato também observado nos melanodermas nos trabalhos de ALEXANDER; HITCHCOCK ${ }^{2}$ e CONNOR; MOSHIRI ${ }^{28}$. Também foram estatisticamente diferentes os valores de overjet e overbite entre as amostras para o sexo masculino. Vale ressaltar que os valores considerados estatisticamente diferentes apresentaram a diferença entre suas médias inferiores a $1 \mathrm{~mm}$, tanto no sexo masculino como no feminino. Esse fato indica que, clinicamente, essa diferença pode não ser importante. (Tabelas 6 e 7).

\subsection{3 - Estruturas do tecido mole}

A literatura tem demonstrado a influência da espessura do tecido mole no perfil facial ${ }^{37,47,83,88}$. Afirmam que o perfil não é apenas um reflexo de medidas esqueléticas, pois o fato de que tecido mole determina muitas características do perfil facial tem sido relatado desde os anos $50^{22,86,101,112}$.

HOLDAWAY ${ }^{50}$ já se preocupava em avaliar a correlação entre perfil mole e ósseo utilizando a medida H-NB. Porém, as medidas específicas da espessura de diferentes pontos da face não eram levadas em consideração. A análise proposta por ARNETT et al. ${ }^{10}$, utilizada no presente trabalho, avalia cuidadosamente a espessura do tecido mole principalmente do terço inferior da face.

Os resultados desta pesquisa demonstraram que a espessura do lábio superior e do mento foi maior, para pessoas de ambos os sexos, nos feodermas brasileiros, fato também observado nos melanodermas, no resultado dos estudos de 
CONNOR; MOSHIRI ${ }^{28}$ e FLYNN; AMBROGIO; ZEICHNER ${ }^{41}$. A espessura do queixo foi maior apenas nas feodermas brasileiras. (Tabelas 8 e 9 )

Nesse sentido chama a atenção a espessura do lábio inferior, a qual foi maior nos leucodermas americanos. No entanto, esse mesmo resultado foi demonstrado por SANT'ANA ${ }^{94}$, que comparou leucodermas brasileiros e americanos. Essa diferença de espessura do lábio inferior pode mascarar uma relação de Classe II e promover um perfil mais reto ou caracterizar um perfil mais côncavo em indivíduos em relação dentoesquelética de Classe I. Para os feodermas, a menor espessura do lábio inferior ressalta o cuidado que o ortodontista deve ter, durante a mecânica, com a movimentação dos incisivos inferiores. Em alguns casos, a retrusão ou inclinação dos incisivos somada à menor espessura do lábio inferior podem provocar um perfil convexo. (Tabelas 8 e 9)

As medidas do ângulo nasolabial e do lábio superior são importantes na determinação do perfil facial e são influenciadas pela posição do incisivo superior e inferior. McNAMARA ${ }^{65}$ (1984) utilizou, em sua análise, o ângulo nasolabial como determinante para o planejamento cirúrgico. No caso em que o ângulo nasalabial estava dentro do padrão não se planejava alteração ântero-posterior da maxila, mesmo quando as medidas esqueléticas indicavam alteração na posição sagital.

O presente trabalho demonstrou um padrão diferente para ângulo nasolabial, em ambos os sexos, entre feodermas brasileiros e leucodermas americanos. As medidas do ângulo nasolabial foram menores nos feodermas brasileiros. Esse resultado indica protrusão da maxila ou dos incisivos superiores e reflete em um perfil mais convexo. Esse resutado está de acordo com outros estudos que evidenciaram um perfil mais reto, com ângulo nasolabial mais aberto, em leucodermas americanos ${ }^{28,41,110}$. (Tabelas 8 e 9)

O ângulo do lábio superior apresentou-se maior nos feodermas, no entanto, sem significância estatística, em concordância com o estudo de CONNOR; $\mathrm{MOSHIRI}^{28}$, comparou um grupo de melanodermas e leucodermas. Esses dados confirmam a relação do lábio superior com a posição do incisivo superior, os quais se apresentaram mais vestibularizados nos feodermas. SANT'ANA ${ }^{94}$, que utilizou a mesma metodologia deste trabalho, encontrou valores menores para leucodermas 
brasileiros, de ambos os sexos, em relação aos leucodermas americanos. (Tabelas 8 e 9).

\subsection{4 - Comprimento facial}

Diferentes estudos presentes na literatura apresentam resultados controversos quanto à altura facial de indivíduos melanodermas. Esses resultados se devem ao fato de a população de descendência africana apresentar sua ascendência de povos vindos de diferentes regiões ${ }^{13,28,33,41}$. Recentemente DANDAJENA; CHUNG; NANDA ${ }^{33}$ encontraram, no povo Shona (etnia africana), uma face mais curta que leucodermas e melanodermas americanos.

As feodermas brasileiras não apresentaram diferenças significativas em relação às leucodermas americanas nas medidas de comprimento facial, comprimento anterior da maxila e comprimento anterior da mandíbula. No estudo realizado por SANT'ANA ${ }^{94}$ essas medidas apresentaram valores estatisticamente diferentes entre leucodermas brasileiras e americanas. No entanto, os valores dos dois grupos foram muito próximos (comprimento facial: brasileiras - 128,10; americanas - 25,7 / comprimento anterior da mandíbula: brasileiras - 49,31; americanas $-48,60)^{94}$. (Tabela 10)

Essas mesmas medidas apresentaram valores estatisticamente diferentes entre os indivíduos do sexo masculino. Nesse caso os feodermas apresentaram valores menores que os leucodermas, indicando uma face mais curta para o feoderma brasileiro. Na literatura, existem trabalhos que mostram os melanodermas apresentando maior altura facial do que os leucodermas ${ }^{37,41,52,107}$. O resultado da altura facial do presente estudo sugere que os feodermas podem ter herdado as características dos brasileiros leucodermas, ou que os melanodermas ascendentes dos feodermas sejam de alguma região da África que apresente características de menor padrão facial. Segundo SANT'ANA ${ }^{94}$, os leucodermas brasileiros também apresentam a face mais curta que os americanos. (Tabela 11)

Quando se consideram as medidas de comprimento apenas do terço inferior da face, observou-se o mesmo padrão visto anteriormente. O terço inferior da 
face foi semelhante entre as amostras do sexo feminino e menor nos feodermas do sexo masculino em relação aos leucodermas americanos. No entanto, para a medida do lábio superior, as amostras apresentaram valores semelhantes em ambos os sexos. A medida do comprimento do lábio inferior não foi diferente para o sexo feminino, mas demonstrou valores estatisticamente diferentes para o sexo masculino, com valores superiores para os leucodermas americanos. Esse resultado está de acordo com a medida do comprimento anterior da mandíbula, que foi menor na amostra dos feodermas. Esse fato comprova que o tecido mole acompanha as características esqueléticas. (Tabelas 10 e 11)

Algumas medidas que compõem o comprimento facial envolvem a relação do tecido mole com os dentes. Dentre essas medidas estão gap interlabial, overbite e exposição de incisivo. Os resultados demonstraram valores estatisticamente diferentes entre as amostras estudadas. Os resultados indicaram maior gap labial e consequentemente maior exposição do incisivo para a amostra de leucodermas, fato também encontrado no estudo de FLYNN; AMBROGIO; ZEICHNER ${ }^{41}$. Essas características comumente acompanham o padrão de face mais vertical, também evidenciado nos leucodermas americanos. (Tabelas 10 e 11)

Assim, a altura facial não deve ser associada exclusivamente a um grupo racial, pois os resultados deste e de outros trabalhos revelam que dentro de um mesmo grupo, a altura facial pode variar. Essas variações devem ser consideradas principalmente no caso de grupos com miscigenação racial, o que é evidente na amostra brasileira deste estudo.

\subsection{5 - Projeção em relação à LVV}

As medidas em relação à LVV revelam a posição ântero-posterior das principais estruturas do tecido mole. Essas medidas representam a associação entre posições dentárias ou esqueléticas e o tecido mole subjacente. A partir da LVV, a face é avaliada nos terços superior e inferior. 
A projeção do terço superior da face, em relação à LVV, é avaliada pelos pontos Glabela, Infra-orbitário Tegumentar, Malar Tegumentar e Subpupilar Tegumentar.

Nas pessoas do sexo feminino, a posição da glabela foi semelhante nas duas amostras. Nas medidas infra-orbitária, malar e subpupilar tegumentar, a face das feodermas apresentou-se menos projetada para anterior em relação às americanas. No entanto, a medida do ponto subpupilar tegumentar não foi estatisticamente diferente. (Tabela 12)

A avaliação da posição do terço superior da face demonstrou diferença estatística, entre as amostras, apenas para a medida do malar tegumentar, revelando maior retrusão nos feodermas, em ambos os sexos. SANT'ANA ${ }^{94}$, ao comparar leucodermas brasileiros e americanos, também encontrou a face do brasileiro com o terço médio menos projetado para anterior. (Tabelas 12 e 13)

As medidas que avaliaram o terço médio da face, ou a maxila, compreendem: Base Nasal, Pronasal, Subnasal, Ponto A Tegumentar, Lábio Superior e Borda do Incisivo Superior.

A maxila apresentou-se mais projetada para anterior, com resultados estatisticamente significantes, nas medidas da base nasal, pronasal e do lábio superior, nas brasileiras. Esses resultados confirmaram a tendência de um perfil suavemente mais protruído nas feodermas brasileiras. Essas características também foram observadas para as melanodermas de alguns trabalhos ${ }^{13,28,42,69,71}$. (Tabela 12)

Nas pessoas do sexo masculino, o terço médio também apresentou-se suavemente mais projetado para anterior com as medidas base nasal, lábio superior e borda do incisivo superior às dos americanos, fato também encontrado em estudos para os melanodermas em alguns estudos comparativos ${ }^{13,37,41}$. (Tabela 13)

A menor projeção do terço superior somada à maior projeção para anterior da maxila colaboram para um perfil mais convexo nos feodermas brasileiros. O grupo de leucodermas apresentaram maior projeção para anterior do terço superior e menor projeção da maxila. Desse modo, em relação à LVV, a face do leucoderma americano apresentou-se mais reta. 
Por fim, compararam-se as medidas do terço inferior da face, utilizando as medidas: borda do incisivo inferior, lábio inferior, ponto B tegumentar e pogônio tegumentar.

Para as medidas referentes à mandíbula, os resultados apresentaram-se semelhantes para ambos os sexos. Apenas a medida do pogônio tegumentar foi estatisticamente diferente, demonstrando maior retrusão do queixo para os feodermas, o que colabora para um perfil mais convexo, como foi observado para os melanodermas em alguns estudos ${ }^{13,28,37,41}$. (Tabelas 12 e 13).

\section{Considerações Clínicas}

Com este trabalho, mais uma vez evidenciou-se a diferença entre as etnias. Ao comparar feodermas com leucodermas, esta pesquisa demonstrou perfil facial diferente. O feoderma apresentou maior protrusão da maxila, retrusão do queixo e perfil mais convexo que os leucodermas.

Essas evidencias indicam que o ortodontista e o cirurgião devem estar atentos às características de seus pacientes durante o planejamento de cada caso. As características de cada etnia ajudam o profissional na decisão de extrações e do envolvimento cirúrgico.

Com base nesta pesquisa, sugerem-se mais estudos, com outras etnias, usando a presente metodologia para ampliar as possibilidades de tratamento ortodôntico e orto-cirúrgico. 
7 - CONCLUSÕES 



\section{7 - CONCLUSÕES}

Com base na metodologia e resultados apresentados no estudo comparativo entre feodermas brasileiros e leucodermas norte americanos, concluiuse que:

Os feodermas brasileiros apresentam um perfil facial diferente dos leucodermas nas seguintes características:

a) Medidas dentoesqueléticas:

O incisivo superior e inferior se apresentaram mais vestibularizados nos feodermas de ambos os sexos.

b) Estruturas do tecido mole:

Os feodermas apresentaram maior espessura do lábio superior, do mento e o ângulo nasolabial mais fechado. Apenas as feodermas brasileiras apresentaram maior espessura do queixo.

c) Comprimento Facial:

Apenas os feodermas do gênero sexo apresentaram a face mais curta. Os leucodermas norte-americanos, de ambos os sexos apresentaram maior comprimento do lábio inferior.

d) Projeção em relação à LVV:

Os feodermas apresentaram maior projeção da maxila, maior retrusão do queixo e um perfil mais convexo. 



\section{REFERÊNCIAS}





\section{REFERÊNCIAS}

1 Alcalde RE, Jinno T, Orsini MG, Sasaki A, Sugiyama RM, Matsumura T. Soft tissue cephalometric norms in Japanese adults. Am J Orthod Dentofacial Orthop. 2000;118(1):84-9.

2 Alexander TL, Hitchcock HP. Cephalometric standards for American Negro children. Am J Orthod. 1978;74(3):298-304.

3 Altemus LA. Cephalofacial relationships. Angle Orthod. 1968;38(3):175-84.

4 Andrews L. Entrevista. Rev Dental Press Orthodont Facial. 1997;2:6-7.

5 Angle EH. Treatment of malocclusion of the teeth. S. S. White ed. Philadelphia; 1907.

6 Ariza DMC, Pinzan A, Henriques JFC. Avaliação comparativa do crescimento maxilomandibular em crianças leucodermas brasileiras, com oclusão normal, utilizando as medidas Co-A, Co-Gn, AFAI e Dif. Mand./Max. da análise proposta por McNamara Jr. . Ortodontia. 1993;26(1):14-37.

$7 \quad$ Arnett GW. Entrevita. Rev Dental Press Orthodont Facial. 1998;3:6-13.

8 Arnett GW, Bergman RT. Facial keys to orthodontic diagnosis and treatment planning-Part I. Am J Orthod Dentofacial Orthop. 1993;103(4):299-312.

9 Arnett GW, Bergman RT. Facial keys to orthodontic diagnosis and treatment planning-Part II. Am J Orthod Dentofacial Orthop. 1993;103(5):395-411.

10 Arnett GW, Jelic JS, Kim J, Cummings DR, Beress A, Worley CM, Jr., et al. Soft tissue cephalometric analysis: diagnosis and treatment planning of dentofacial deformity. Am J Orthod Dentofacial Orthop. 1999;116(3):239-53.

11 Arnett GW, McLaughlin R. Facial and planning for orthodontists and oral surgeons Mosby ed. Edinburgh; 2004.

12 Auger TA, Turley PK. The female soft tissue profile as presented in fashion magazines during the 1900s: a photographic analysis. Int J Adult Orthodon Orthognath Surg. 1999;14(1):7-18.

13 Bacon W, Girardin P, Turlot JC. A comparison of cephalometric norms for the African Bantu and a caucasoid population. Eur J Orthod. 1983;5(3):233-40.

14 Baumrind S, Frantz RC. The reliability of head film measurements. 2. Conventional angular and linear measures. Am J Orthod. 1971;60(5):505-17.

15 Bergman RT. Cephalometric soft tissue facial analysis. Am J Orthod Dentofacial Orthop. 1999;116(4):373-89. 
16 Bertoz FA, Martins DR. Determinação da linha "I" em melanodermas brasileiros, masculinos de 12 a 17 anos, com oclusão normal. Ortodontia. 1981;14(3):186-98.

17 Bittner C, Pancherz H. Facial morphology and malocclusions. Am J Orthod Dentofacial Orthop. 1990;97(4):308-15.

18 Borman H, Ozgur F, Gursu G. Evaluation of soft-tissue morphology of the face in 1,050 young adults. Ann Plast Surg. 1999;42(3):280-8.

19 Bowker WD, Meredith HV. A metric analysis of the facial profile Angle Orthod. $1959 ; 29(3): 149-60$.

20 Broadbent $\mathrm{BH}$. A new x-ray technique and its application to orthodontia Angle Orthod. 1931;1(2):45-66.

21 Burstone CJ. The integumental profile. Am J Orthod. 1958;44(1):1-25.

22 Burstone CJ. The integumental contour and extension patterns. Angle Orthod. 1959;29(2):93-104.

23 Burstone CJ, James RB, Legan H, Murphy GA, Norton LA. Cephalometrics for orthognathic surgery. J Oral Surg. 1978;36(4):269-77.

24 Capelozza FL. Diagnótico em ortodontia. Maringa; 2004.

25 Capelozza L, de Araaujo Almeida G, Mazzottini R, Cardoso Neto J. Maxillomandibular relationships in patients with dentofacial deformities: diagnostic criteria utilizing three cephalometric analyses. Int J Adult Orthodon Orthognath Surg. 1989;4(1):13-26.

26 Carrea U. Tratado de ortodontia. Buenos Aires; 1942.

27 Chaves AP, Ferreira RI, Araújo TM. Maturação esquelética nas raças brancas e negras. Ortodontia Gaúcha. 1999;3(1):45-52.

28 Connor AM, Moshiri F. Orthognathic surgery norms for American black patients. Am J Orthod. 1985;87(2):119-34.

29 Cotton WN, Takano WS, Wong WL. The Dons analysis applied to three other ethnic groups. Angle Orthod. 1951;21:213-20.

30 Cox NH, van der Linden FP. Facial harmony. Am J Orthod. 1971;60(2):175-83.

31 Czarnecki ST, Nanda RS, Currier GF. Perceptions of a balanced facial profile. Am J Orthod Dentofacial Orthop. 1993;104(2):180-7.

32 Dahlberg G. Statistical methods for medical and biological students. New York 1940.

33 Dandajena TC, Chung KW, Nanda RS. Assessment of anterior face height in a native African sample. Am J Orthod Dentofacial Orthop. 2006;130(2):196-201. 
34 Dierkes JM. The beauty of the face: an orthodontic perspective. J Am Dent Assoc. 1987;Spec No:89E-95E.

35 Downs WB. Analysis of the dentofacial profile. Angle Orthod. 1956;26(4):191212.

36 Drobocky OB, Smith RJ. Changes in facial profile during orthodontic treatment with extraction of four first premolars. Am J Orthod Dentofacial Orthop. 1989;95(3):220-30.

37 Drummond R. A determination of cephalometric norms of the Negro race. Am J Orthod. 1968;54:670-82.

38 Enciclopédia Deltalarousse. In: SA ED. 1965.

39 Farrow AL, Zarrinnia K, Azizi K. Bimaxillary protrusion in black Americans--an esthetic evaluation and the treatment considerations. Am J Orthod Dentofacial Orthop. 1993;104(3):240-50.

40 Fitzgerald JP, Nanda RS, Currier GF. An evaluation of the nasolabial angle and the relative inclinations of the nose and upper lip. Am J Orthod Dentofacial Orthop. 1992;102(4):328-34.

41 Flynn TR, Ambrogio RI, Zeichner SJ. Cephalometric norms for orthognathic surgery in black American adults. J Oral Maxillofac Surg. 1989;47(1):30-9.

42 Fonseca RJ, Klein WD. A cephalometric evaluation of American Negro women. Am J Orthod. 1978;73(2):152-60.

43 Freitas MR. Estudo analítico e comparativo do perfil facial mole, em adolescentes brasileiros, leucodermas, apresentando "oclusão normal", com as diversas linhas estéticas preconizadas [dissertação]. Bauru (SP): Faculdade de Odontologia de Bauru, Universidade de São Paulo; 1978.

44 Graber TM. A critical review of clinical cephalometric radiography. Am J Orthod. 1954;40(1):1-26.

45 Graber TM. Problems and limitations of cephalometric analysis in orthodontics. J Am Dent Assoc. 1956;53(4):439-54.

46 Gravely JF, Benzies PM. The clinical significance of tracing error in cephalometry. Br J Orthod. 1974;1(3):95-101.

47 Hambleton RS. The soft tissue covering of the skeletal face as related to orthodontic problems. Am J Orthod. 1964;50(6):405-20.

48 Henriques JFC, Pinzan A, Takahashi R, Freitas MR. Determinação da medida de Wits para jovens nipo-brasileiros com "oclusão normal". Rev Dental Press Orthodont Facial. 1999;4(6):35-41.

49 Holdaway RA. A soft-tissue cephalometric analysis and its use in orthodontic treatment planning. Part I. Am J Orthod. 1983;84(1):1-28. 
50 Holdaway RA. A soft-tissue cephalometric analysis and its use in orthodontic treatment planning. Part II. Am J Orthod. 1984;85(4):279-93.

51 Houston WJ. The analysis of errors in orthodontic measurements. Am J Orthod. 1983;83(5):382-90.

52 Huang WJ, Taylor RW, Dasanayake AP. Determining cephalometric norms for Caucasians and African Americans in Birmingham. Angle Orthod. 1998;68(6):503-11; discussion 12.

53 lague Neto G. Avaliação do perfil tegumentar e a sua relação com as estruturas dentoesqueléticas maxilomandibulares, em adultos jovens portadores de oclusão normal e boa estética facial [dissertação]. Bauru (SP): Faculdade de Bauru, Universidade de São Paulo; 1998.

54 Interlandi S. Linha "I" na análise morfodiferencial para o dagnóstico ortodôntico. Rev Fac Odont USP. 1971;9:289-310.

55 Ioi H, Nakata S, Nakasima A, Counts A. Effect of facial convexity on anteroposterior lip positions of the most favored Japanese facial profiles. Angle Orthod. 2005;75(3):326-32.

56 Johnston C, Hunt O, Burden D, Stevenson M, Hepper P. The influence of mandibular prominence on facial attractiveness. Eur J Orthod. 2005;27(2):12933.

57 Kowalski CJ, Nasjleti CE, Walker GF. Differential diagnosis of adult male black and white populations. Angle Orthod. 1974;44(4):346-50.

58 Krogman WM, Sassouni V. Syllabus in roentgenographic cephalometry. Philadelphia; c1957.

59 Legan HL, Burstone CJ. Soft tissue cephalometric analysis for orthognathic surgery. J Oral Surg. 1980;38(10):744-51.

60 Lew KK, Ho KK, Keng SB, Ho KH. Soft-tissue cephalometric norms in Chinese adults with esthetic facial profiles. J Oral Maxillofac Surg. 1992;50(11):1184-9; discussion 9-90.

61 Lusterman EA. The esthetics of occidental face: a study of dentofacial morphology based upon anthopologic criteria. Am J Orthod. 1963;49(11):82650.

62 Machado Filho J. Perfis dos "tipos" brasileiros brancos masculinos. Ortodontia. 1969;12(2-3):113-32.

63 Maple JR, Vig KW, Beck FM, Larsen PE, Shanker S. A comparison of providers' and consumers' perceptions of facial-profile attractiveness. Am J Orthod Dentofacial Orthop. 2005;128(6):690-6; quiz 801.

64 Martins DR. Estudo comparativo dos valores cefalométricos das análises de Dows, Steiner e Alabama, com os adolescentes brasileiros, leucodermas, de 
origem mediterrânea [tese]. Bauru (SP): Faculdade de Bauru, Universidade de São Paulo; 1979.

65 McNamara JA, Jr. A method of cephalometric evaluation. Am J Orthod. 1984;86(6):449-69.

66 McNamara JA, Jr., Ellis E, 3rd. Cephalometric analysis of untreated adults with ideal facial and occlusal relationships. Int J Adult Orthodon Orthognath Surg. 1988;3(4):221-31.

67 Medeiros MAQB. Estudo cefalométrico do padrão dentário de jovens melanodermas brasileiros do sexo feminino, com "oclusão normal" [dissertação]. Bauru (SP): Faculdade de Odontologia de Bauru, Universidade de São Paulo; 1986.

68 Merrifield LL. The profile line as an aid in critically evaluating facial esthetics. Am J Orthod. 1966;52(11):804-22.

69 Moraes C, Freitas MR, Henriques JFC. Cefalometria - Determinação do padrão esquelético das adolescentes melanodermas brasileiras, com "oclusão normal" Ortodontia. 1988;22(4):4-14.

70 Naidoo LC, Miles LP. An evaluation of the mean cephalometric values for orthognathic surgery for black South African adults. Part 1: Hard tissue. J Dent Assoc S Afr. 1997;52(7):495-502.

71 Naidoo LC, Miles LP. An evaluation of the mean cephalometric values for orthognathic surgery for black South African adults. Part II: Soft tissue. J Dent Assoc S Afr. 1997;52(9):545-50.

72 Nanda RS, Ghosh J. Facial soft tissue harmony and growth in orthodontic treatment. Semin Orthod. 1995;1(2):67-81.

73 Neger MA. A quantitative method for the evaluation of tissue facial profile. Am J Orthod. 1959;45(10):735-51.

74 Nguyen DD, Turley PK. Changes in the Caucasian male facial profile as depicted in fashion magazines during the twentieth century. Am J Orthod Dentofacial Orthop. 1998;114(2):208-17.

75 Okuyama CC. Preferência do perfil tegumentar em jovens melanodermas, leucodermas e xantodermas de ambos os sexos, avaliados por ortodontistas, leigos e artistas [dissertação]. Bauru (SP): Faculdade de Odontologia de Bauru, Universidade de São Paulo; 1995.

76 Park YC, Burstone CJ. Soft-tissue profile--fallacies of hard-tissue standards in treatment planning. Am J Orthod Dentofacial Orthop. 1986;90(1):52-62.

77 Peck H, Peck S. A concept of facial esthetics Angle Orthod. 1970;40(4):284318. 
78 Perrett DI, May KA, Yoshikawa S. Facial shape and judgements of female attractiveness. Nature. 1994;368(6468):239-42.

79 Pinzan, et., al. Estudo do crescimento maxilomandibular em jovens leucodermas, oclusão normal (dos 5 aos 12 anos de idade), de ambos os sexos, utilizando as normas Co-A, Co-Gn, Dif. Mand./Max. e AFAl Ortodontia. 1993;30(2):52-69.

80 Pinzan A. "Upgrade" nos conceitos da interpretação das medidas cefalométricas. São Paulo: Santos, 2006.41-5.

81 Polk MS, Jr., Farman AG, Yancey JA, Gholston LR, Johnson BE, Regennitter FJ. Soft tissue profile: a survey of African-American preference. Am J Orthod Dentofacial Orthop. 1995;108(1):90-101.

82 Poulton DR. Facial esthetics and angles. Angle Orthod. 1957;27(3):133-37.

83 Proffit WR, White JRP, Saver DM. Conteporary treatment of dentofacial deformity. St. Luis: Mosby.; 2003.

84 Reis SAB, Capelozza FL, Mandetta S. Prevalência de oclusão normal e má oclusão em brasileiros, adultos, leucodermas, caracterizados pela normalidade do perfil facial. Rev Dental Press Orthodont Facial. 2002;7(5):17-25.

85 Richardson ER. Racial differences in dimensional traits of the human face. Angle Orthod. 1980;50(4):301-11.

86 Ricketts RM. Paning tretment on the basis of facial pattern and an estimate of its growth. Angle Orthod. 1957;27(1):14-37.

87 Ricketts RM. Cephalometric synthesis: an exercise in stating objectives planning treatment with tracing of the head roentgenogram. Am J Orthod. 1960;46(9):647-73.

88 Ricketts RM. Esthetics, environment, and the law of lip relation. Am J Orthod. 1968;54(4):272-89.

89 Riedel RA. Esthetics and its relation to orthodontic therapy. Angle Orthod. 1950;20(3):168-78.

90 Riedel RA. An analysis of dentofacial relationships. Am J Orthod. 1957;43(2):103-19.

91 Rino JN. Atratividade facial avaliada por profissionais das áreas de saúde, estética e por leigos [tese]. São Paulo (SP): Faculdade de Odontologia da Universidade de São Paulo; 2006.

92 Rivera SM, Hatch JP, Dolce C, Bays RA, Van Sickels JE, Rugh JD. Patients' own reasons and patient-perceived recommendations for orthognathic surgery. Am J Orthod Dentofacial Orthop. 2000;118(2):134-41. 
93 Robison JM, Rinchuse DJ, Zullo TG. Relationship of skeletal pattern and nasal form. Am J Orthod. 1986;89(6):499-506.

94 Sant'Ana E. Avaliação comparativa do padrão de normalidade do perfil facial em pacientes brasileiros leucodermas com o norte americano [tese]. Bauru (SP): Faculdade de Odontologia de Bauru, Universidade de São Paulo; 2005.

95 Sassouni V. Diagnosis and treatment planning via roentgenographic cephlometry Am J Orthod. 1958;44(6):433-63.

96 Scavone H, Jr., Trevisan H, Jr., Garib DG, Ferreira FV. Facial profile evaluation in Japanese-Brazilian adults with normal occlusions and well-balanced faces. Am J Orthod Dentofacial Orthop. 2006;129(6):721 e1-5.

97 Scheideman GB, Bell WH, Legan HL, Finn RA, Reisch JS. Cephalometric analysis of dentofacial normals. Am J Orthod. 1980;78(4):404-20.

98 Scott SH, Johnston LE, Jr. The perceived impact of extraction and nonextraction treatments on matched samples of African American patients. Am J Orthod Dentofacial Orthop. 1999;116(3):352-60.

99 So LL, Davis PJ, King NM. "Wits" appraisal in southern Chinese children. Angle Orthod. 1990;60(1):43-8 apud Henriques JFC, Pinzan A, Takahashi R, Freitas MR. Determinação da medida de Wits para jovens nipo-brasileiros com "oclusão normal". Rev Dental Press Orthodont Facial. 1999;4(6):35-41.

100 Steiner CC. Cephalometrics for you and me Am J Orthod. 1953;39(10):729-55.

101 Stoner MM, al. e. A cephalometric evaluation of fifty-seven consecutive cases treated by Dr. Charles H. Teweed Angle Orthod. 1956;26(2):68-98.

102 Suguino R, al. e. Entrevista. Rev Dental Press Orthodont Facial. 1996;1:86-107.

103 Sushner NI. A photographic study of the soft-tissue profile of the Negro population. Am J Orthod. 1977;72(4):373-85.

104 Todd SA, Hammond P, Hutton T, Cochrane S, Cunningham S. Perceptions of facial aesthetics in two and three dimensions. Eur J Orthod. 2005;27(4):363-9.

105 Tweed $\mathrm{CH}$. Indications for the extraction of teeth in orthodontic procedure. Am J Orthod. 1944;30:405-28.

106 Tweed $\mathrm{CH}$. The Frankfort-Mandibular Incisor Angle (FMIA) in orthodontic diagnosis, treatment planning and prognosis. Angle Orthod. 1954;24(3):121-69.

107 Uchiyama LMAF. Estudo cefalométrico das alturas faciais anterior e posterior, em jovens brasileiros melanodermas, com "oclusão normal" [dissertação]. Bauru (SP): Faculdade de Odontologia de Bauru, Universidade de São Paulo; 2005.

108 Viazis A. Atlas of orthodontics: principles and clinical applications. W. B. Saunders ed. Philadelphia; 1993. 
109 Willians R. The diagnostic line. Am J Orthod. 1969;55(5):458-76.

110 Worms FW, Isaacson RJ, Speidel TM. Surgical orthodontic treatment planning: profile analysis and mandibular surgery. Angle Orthod. 1976;46(1):1-25.

111 Wuerpal E. On facial balance and harmony. Angle Orthod. 1937;7:81-9.

112 Wylie WL. The mandibule incisor: its role in facial estetics. Angle Orthod. 1955;25(1):32-41.

113 Wylie WL. Discussion of "the lower incisor: its influence on treatment and esthetics". Am J Orthod. 1959;45(1):50-4.

114 Yehezkel S, Turley PK. Changes in the African American female profile as depicted in fashion magazines during the 20th century. Am J Orthod Dentofacial Orthop. 2004;125(4):407-17. 
ABSTRACT 



\section{ABSTRACT}

The aim of this study was to check the measure of Brazilian-AfricanCaucasian descents facial profile (experimental group) in comparison to North American Caucasians (control group) standardized measures (ARNETT). The experimental group was comprised by 39 lateral norm teleradiographies, performed from 20 females and 19 males, ranging from 18 to 35 years old, in which a "normal occlusion" not submitted to orthodontic treatment was verified. After digitalization, the radiographies were analyzed with the aid of the software Dolphin 9.0 in order to accomplish the cephalometric measures from the Cephalometric Soft Tissue Analysis proposed by ARNETT. T-test analysis $(p<0.05)$ of the results showed that the male and female African-Caucasian descents presented more vestibularized superior and inferior incisives, larger superior lip and menton thickness, smaller nasolabial angle, smaller length of inferior lip, larger maxillary projection, larger chin retrusion and convexer profile. Only the female Brazilian African-Caucasian group revealed larger chin thickness and facial height similar to the female North Americans Caucasian. Based on the above figures, it can be concluded that the Brazilian African-Caucasian descents facial profile is significantly different from the North Americans', what may indicate a different approach in terms of planning. 

APÊNDICE 

APÊNDICE 1 - Medidas dentoesqueléticas dos feodermas brasileiros

\begin{tabular}{|c|c|c|c|c|c|c|}
\hline Sujeito & Sexo & $\begin{array}{c}\text { Altura posterior da } \\
\text { max. (POM-LVV) }\end{array}$ & IS-POM(0) & II POMd(0) & $\begin{array}{l}\text { Overjet } \\
(\mathrm{mm})\end{array}$ & $\begin{array}{l}\text { Overbite } \\
\text { (mm) }\end{array}$ \\
\hline 1 & $m$ & 94,3 & 58,3 & 61,6 & 3,7 & 0,5 \\
\hline 2 & $\mathrm{~m}$ & 98 & 59,3 & 61,3 & 5,5 & 2,6 \\
\hline 3 & $\mathrm{~m}$ & 97,3 & 53,3 & 60,8 & 3,5 & 2,3 \\
\hline 4 & $\mathrm{~m}$ & 90,7 & 59,3 & 69,2 & 2,8 & 0,9 \\
\hline 5 & $\mathrm{~m}$ & 98,8 & 54,1 & 59,6 & 2,4 & $-1,2$ \\
\hline 6 & $\mathrm{~m}$ & 101,7 & 54,3 & 49,4 & 6 & 7,3 \\
\hline 7 & $\mathrm{~m}$ & 95,6 & 43,2 & 63,9 & 3,4 & 1,7 \\
\hline 8 & $\mathrm{~m}$ & 96,6 & 53 & 60 & 4,1 & 3,8 \\
\hline 9 & $\mathrm{~m}$ & 95,3 & 53,4 & 61,7 & 4 & 1,8 \\
\hline 10 & $\mathrm{~m}$ & 91,2 & 52,7 & 52 & 4,7 & 2 \\
\hline 11 & $\mathrm{~m}$ & 95,4 & 47,9 & 55,8 & 2,8 & 1,2 \\
\hline 12 & $\mathrm{~m}$ & 102,5 & 61,7 & 56 & 4,2 & 5,1 \\
\hline 13 & $\mathrm{~m}$ & 98,4 & 57,4 & 58,5 & 4,4 & 3 \\
\hline 14 & $\mathrm{~m}$ & 99,6 & 55,3 & 72,9 & 3,7 & 2,1 \\
\hline 15 & $\mathrm{~m}$ & 100,5 & 51,8 & 55,2 & 4,1 & 2,1 \\
\hline 16 & $\mathrm{~m}$ & 97,2 & 58,6 & 52,3 & 4,3 & 3,4 \\
\hline 17 & $\mathrm{~m}$ & 103,5 & 50 & 64,4 & 2,9 & 0,8 \\
\hline 18 & $\mathrm{~m}$ & 101,6 & 54,4 & 66,3 & 3,8 & 1,2 \\
\hline 19 & $\mathrm{~m}$ & 97,7 & 54,9 & 62,3 & 4,6 & 3,1 \\
\hline 20 & $f$ & 101,2 & 56 & 52,8 & 4,2 & 3,9 \\
\hline 21 & $f$ & 102,1 & 51,5 & 62 & 3,8 & 1,6 \\
\hline 22 & $f$ & 91,3 & 59,2 & 56,8 & 3 & 1 \\
\hline 23 & $f$ & 99,9 & 54,7 & 61,9 & 3,3 & 2,9 \\
\hline 24 & $f$ & 98,7 & 57,1 & 58,7 & 2,5 & 1,2 \\
\hline 25 & $f$ & 99 & 49,5 & 51,6 & 2,6 & 0,3 \\
\hline 26 & $f$ & 102,3 & 49,3 & 51,1 & 3,3 & 3,2 \\
\hline 27 & $f$ & 89,9 & 54,4 & 56,2 & 2,9 & 1,7 \\
\hline 28 & $f$ & 98,9 & 50,3 & 71,2 & 4,2 & 2,5 \\
\hline 29 & $f$ & 96,8 & 52,7 & 56,9 & 3,5 & 2,9 \\
\hline
\end{tabular}


APÊNDICE 1 - (Cont.)

\begin{tabular}{ccccccc}
\hline Sujeito & Sexo & $\begin{array}{c}\text { Altura posterior da } \\
\text { max. (POM-LVV) }\end{array}$ & IS-POM(0) & II POMd(0) & $\begin{array}{c}\text { Overjet } \\
\text { ( } \mathbf{m m})\end{array}$ & $\begin{array}{c}\text { Overbite } \\
\text { ( } \mathbf{m m} \text { ) }\end{array}$ \\
\hline 30 & $\mathrm{f}$ & 117,5 & 46,7 & 74,4 & 2,4 & 3 \\
31 & $\mathrm{f}$ & 105 & 46,3 & 59,4 & 2,9 & 1,3 \\
32 & $\mathrm{f}$ & 106,6 & 65 & 65,1 & 3,4 & 4,6 \\
33 & $\mathrm{f}$ & 95,9 & 46,7 & 52,5 & 3,7 & 2,7 \\
34 & $\mathrm{f}$ & 101,1 & 56,2 & 65,6 & 2,3 & 2,5 \\
35 & $\mathrm{f}$ & 100,4 & 56,3 & 63,3 & 3,4 & 1,2 \\
36 & $\mathrm{f}$ & 98 & 54,6 & 55,2 & 3,1 & 2,1 \\
37 & $\mathrm{f}$ & 103,4 & 56,9 & 64,7 & 3,6 & 3,6 \\
38 & $\mathrm{f}$ & 105,8 & 54,8 & 66 & 4,2 & 2,7 \\
39 & $\mathrm{f}$ & 102 & 60,4 & 69,3 & 2,1 & \\
\hline
\end{tabular}


APÊNDICE 2 - Medidas do tecido mole dos feodermas brasileiros

\begin{tabular}{|c|c|c|c|c|c|c|c|}
\hline Sujeito & Sexo & $\begin{array}{c}\text { Espessura } \\
\text { do lab, } \\
\text { sup,(mm) }\end{array}$ & $\begin{array}{l}\text { Espessura do } \\
\text { lab, inf,(mm) }\end{array}$ & $\begin{array}{c}\text { Espessura do } \\
\text { queixo } \\
\text { (Pog-Pog') (mm) }\end{array}$ & $\begin{array}{c}\text { Espessura do } \\
\text { mento (Me-Me') } \\
(\mathrm{mm})\end{array}$ & $\begin{array}{c}\text { Ângulo } \\
\text { nasolabial (0) }\end{array}$ & $\begin{array}{l}\text { Ângulo do } \\
\text { lábio sup, (0) }\end{array}$ \\
\hline 1 & $\mathrm{~m}$ & 19,6 & 13,4 & 17,2 & 12,4 & 96,7 & 15,8 \\
\hline 2 & $\mathrm{~m}$ & 17,3 & 12 & 15,7 & 14,3 & 118,5 & 4,9 \\
\hline 3 & $\mathrm{~m}$ & 19,1 & 13,5 & 11,8 & 13,2 & 96,2 & 18,2 \\
\hline 4 & $\mathrm{~m}$ & 16,1 & 11,4 & 14,5 & 17,2 & 89,1 & 14 \\
\hline 5 & $\mathrm{~m}$ & 22,6 & 14,3 & 8,6 & 8,6 & 87,6 & 26,8 \\
\hline 6 & $\mathrm{~m}$ & 14,9 & 10,4 & 16,2 & 10,2 & 104,2 & 8,8 \\
\hline 7 & $\mathrm{~m}$ & 20,7 & 15,4 & 16,9 & 15,9 & 75,6 & 27,4 \\
\hline 8 & $\mathrm{~m}$ & 13,9 & 8,9 & 13,7 & 11 & 103,2 & $-2,3$ \\
\hline 9 & $\mathrm{~m}$ & 19 & 13,6 & 19,7 & 19 & 83 & 29,6 \\
\hline 10 & $\mathrm{~m}$ & 12,8 & 12,7 & 12 & 13,9 & 96,5 & 10,1 \\
\hline 11 & $\mathrm{~m}$ & 15,7 & 14,9 & 13,9 & 17,1 & 104,7 & 8,7 \\
\hline 12 & $\mathrm{~m}$ & 16,8 & 11,6 & 13,5 & 14,6 & 101,2 & 5,1 \\
\hline 13 & $\mathrm{~m}$ & 16,3 & 12,2 & 16,6 & 14,4 & 109,3 & 2,3 \\
\hline 14 & $\mathrm{~m}$ & 15,5 & 8,5 & 18,4 & 20,7 & 100,6 & 11,5 \\
\hline 15 & $\mathrm{~m}$ & 15,5 & 12,9 & 14,9 & 17 & 106,4 & 8,3 \\
\hline 16 & $\mathrm{~m}$ & 16,4 & 9,6 & 15,8 & 11,5 & 92,1 & 17,7 \\
\hline 17 & $\mathrm{~m}$ & 13,3 & 11,3 & 16,3 & 17,2 & 106,8 & 8 \\
\hline 18 & $\mathrm{~m}$ & 17,8 & 10,7 & 14,4 & 16,7 & 97,6 & 17 \\
\hline 19 & $\mathrm{~m}$ & 12,9 & 6,6 & 15,6 & 17,2 & 99,8 & 6,5 \\
\hline 20 & $f$ & 15 & 11,9 & 8,7 & 9,3 & 114,8 & $-2,1$ \\
\hline 21 & $f$ & 15,9 & 13,3 & 12,7 & 14,5 & 108,7 & 11,8 \\
\hline 22 & $f$ & 19,3 & 10,5 & 16,7 & 16,6 & 89,4 & 23,7 \\
\hline 23 & $f$ & 18,8 & 12 & 15 & 12,4 & 100,8 & 17,4 \\
\hline 24 & $f$ & 9,6 & 11,5 & 8,8 & 14,1 & 96,9 & 15,4 \\
\hline 25 & $f$ & 16,6 & 9,5 & 17,6 & 11,6 & 91,1 & 29,1 \\
\hline 26 & $f$ & 19,3 & 15,1 & 14 & 12 & 94,2 & 17,3 \\
\hline 27 & $f$ & 14,9 & 14 & 11,7 & 9,6 & 98,5 & 17,3 \\
\hline 28 & $f$ & 17,9 & 10,9 & 12,3 & 11,1 & 102,9 & 10,6 \\
\hline 29 & $f$ & 14,9 & 12,4 & 12,2 & 13,5 & 97,5 & 16,9 \\
\hline
\end{tabular}




\begin{tabular}{|c|c|c|c|c|c|c|c|}
\hline Sujeito & Sexo & $\begin{array}{c}\text { Espessura } \\
\text { do lab, } \\
\text { sup,(mm) } \\
\end{array}$ & $\begin{array}{l}\text { Espessura do } \\
\text { lab, inf,(mm) }\end{array}$ & $\begin{array}{c}\text { Espessura do } \\
\text { queixo } \\
\text { (Pog-Pog') (mm) }\end{array}$ & $\begin{array}{c}\text { Espessura do } \\
\text { mento (Me-Me') } \\
(\mathrm{mm}) \\
\end{array}$ & $\begin{array}{c}\text { Ângulo } \\
\text { nasolabial (0) }\end{array}$ & $\begin{array}{l}\text { Ângulo do } \\
\text { lábio sup, (0) }\end{array}$ \\
\hline 30 & $f$ & 15 & 11,2 & 13,4 & 12,7 & 101,5 & $-0,3$ \\
\hline 31 & $f$ & 15,5 & 11,1 & 11,7 & 10,5 & 111,6 & $-1,3$ \\
\hline 32 & $f$ & 18,9 & 9,6 & 12,5 & 11,9 & 95,7 & 14,5 \\
\hline 33 & $f$ & 12,4 & 14,4 & 12,2 & 11,2 & 87,9 & 28,5 \\
\hline 34 & $f$ & 19 & 10,1 & 17,6 & 19,8 & 93,6 & 23,8 \\
\hline 35 & $f$ & 17,7 & 12 & 19,1 & 19,5 & 90 & 26,2 \\
\hline 36 & $f$ & 11,7 & 10,5 & 14,4 & 17,6 & 99,7 & 13,2 \\
\hline 37 & $f$ & 20,3 & 10,9 & 16,7 & 15,1 & 90,9 & 9,2 \\
\hline 38 & $f$ & 14,4 & 8,9 & 16,4 & 20 & 113,7 & 4,4 \\
\hline 39 & $f$ & 18,7 & 12,6 & 12,9 & 14 & 94,5 & 21,7 \\
\hline
\end{tabular}


APÊNDICE 3 - Medidas do comprimento facial dos feodermas brasileiros

\begin{tabular}{|c|c|c|c|c|c|c|c|c|c|c|}
\hline Sujeito & Sexo & $\begin{array}{l}\text { Comprimento } \\
\text { Facial (mm) }\end{array}$ & $\begin{array}{c}\text { Comprimento } \\
\text { do lábio sup. } \\
(\mathrm{mm})\end{array}$ & $\begin{array}{l}\text { Gap interlabial } \\
(\mathrm{mm})\end{array}$ & $\begin{array}{l}\text { Comprimento } \\
\text { do lábio inf. } \\
(\mathrm{mm})\end{array}$ & $\begin{array}{l}\text { Terço inferior } \\
\text { da face }(\mathrm{mm})\end{array}$ & $\begin{array}{l}\text { Overbite } \\
\text { (mm) }\end{array}$ & $\begin{array}{l}\text { Exposição } \\
\text { de incisivo } \\
(\mathrm{mm})\end{array}$ & $\begin{array}{l}\text { Comprimento } \\
\text { anterior da } \\
\text { maxila (mm) }\end{array}$ & $\begin{array}{l}\text { Comprimento } \\
\text { anterior da } \\
\text { mandíbula } \\
(\mathrm{mm})\end{array}$ \\
\hline 1 & $\mathrm{~m}$ & 142,6 & 25,5 & 2,1 & 55,7 & 83,6 & 0,5 & 1 & 26,7 & 57 \\
\hline 2 & $\mathrm{~m}$ & 131,1 & 20,3 & 1,6 & 47,7 & 69,6 & 2,6 & 2,1 & 22,4 & 49,8 \\
\hline 3 & $\mathrm{~m}$ & 139,6 & 24,1 & 0,7 & 53,2 & 77,9 & 2,3 & 0,9 & 25 & 55,2 \\
\hline 4 & $\mathrm{~m}$ & 126,6 & 21,8 & 0,9 & 52,8 & 75,4 & 0,9 & 2,9 & 24,7 & 51,6 \\
\hline 5 & $\mathrm{~m}$ & 131,4 & 27,5 & 3,2 & 49,8 & 80,4 & 0,1 & 2,8 & 30,3 & 49 \\
\hline 6 & $\mathrm{~m}$ & 124,7 & 21,7 & 0,6 & 48,6 & 70,9 & 5,3 & 4,1 & 25,8 & 52,4 \\
\hline 7 & $\mathrm{~m}$ & 132,6 & 22,2 & 0,1 & 55,3 & 77,4 & 1,7 & 0,5 & 22,7 & 56,4 \\
\hline 8 & $\mathrm{~m}$ & 131,9 & 23,3 & 1,6 & 46,7 & 71,6 & 3,8 & -1 & 22,2 & 53,1 \\
\hline 9 & $\mathrm{~m}$ & 126,1 & 22,7 & 0,3 & 52,5 & 75,5 & 1,8 & 2,2 & 24,9 & 52,5 \\
\hline 10 & $\mathrm{~m}$ & 129,1 & 15,7 & 2,5 & 50,9 & 69 & 2 & 3,7 & 19,4 & 51,6 \\
\hline 11 & $\mathrm{~m}$ & 147,7 & 28 & 3 & 56,4 & 87,4 & 1,2 & 3,4 & 31,4 & 57,2 \\
\hline 12 & $\mathrm{~m}$ & 125,9 & 21,6 & 2,1 & 45,2 & 68,9 & 5,1 & 2,6 & 24,2 & 49,8 \\
\hline 13 & $\mathrm{~m}$ & 131,6 & 27,4 & 2,4 & 49,5 & 79,3 & 3 & 1,4 & 28,8 & 53,5 \\
\hline 14 & $\mathrm{~m}$ & 133,4 & 25,6 & 1,9 & 53 & 80,5 & 2,1 & 3 & 28,6 & 54 \\
\hline 15 & $\mathrm{~m}$ & 142,3 & 28 & 1,4 & 56,2 & 85,6 & 2,1 & 2 & 30 & 57,8 \\
\hline 16 & $\mathrm{~m}$ & 119,8 & 21,7 & 2,3 & 44,1 & 68,1 & 3,4 & 3,4 & 25,1 & 46,4 \\
\hline 17 & $\mathrm{~m}$ & 123,1 & 23,5 & 1,5 & 45,2 & 70,3 & 0,8 & 0,1 & 23,6 & 47,5 \\
\hline 18 & $\mathrm{~m}$ & 134,4 & 25,7 & 2,9 & 54,4 & 83 & 1,2 & 3,5 & 29,2 & 55 \\
\hline 19 & $\mathrm{~m}$ & 116,8 & 23,5 & 0,9 & 42,4 & 66,7 & 3,1 & 1,1 & 24,6 & 45,2 \\
\hline 20 & $f$ & 113,1 & 18,3 & 1,6 & 40,2 & 60,1 & 3,9 & 4,1 & 22,4 & 41,6 \\
\hline 21 & $f$ & 123,7 & 24,9 & 1,7 & 46,1 & 72,7 & 1,6 & 2,1 & 26,9 & 47,4 \\
\hline 22 & $f$ & 119,9 & 21,9 & 0,6 & 46,5 & 68,9 & 0,9 & $-0,6$ & 21,3 & 48,4 \\
\hline 23 & $f$ & 121,1 & 22,3 & 1,4 & 48,6 & 72,2 & 2,9 & 2,3 & 24,6 & 50,6 \\
\hline 24 & $f$ & 100,4 & 17,4 & 2 & 37,5 & 56,8 & 1,2 & 0,8 & 18,2 & 39,9 \\
\hline 25 & $f$ & 117,2 & 20,9 & 0 & 43,5 & 64,3 & 0,3 & $-0,4$ & 20,5 & 44,2 \\
\hline 26 & $f$ & 130,9 & 23,3 & 1,9 & 51,7 & 76,8 & 3,2 & 5,4 & 28,7 & 51,3 \\
\hline 27 & $f$ & 118,4 & 22,6 & 2,3 & 48,6 & 73,5 & 1,7 & 3,9 & 26,4 & 48,7 \\
\hline 28 & $f$ & 120,3 & 20,5 & 1,3 & 49,1 & 70,9 & 2,5 & 2,1 & 22,6 & 50,8 \\
\hline 29 & $f$ & 117,1 & 19 & 1,3 & 46,1 & 66,4 & 2,9 & 0,4 & 19,5 & 49,9 \\
\hline
\end{tabular}


APÊNDICE 3 - (Cont.)

\begin{tabular}{|c|c|c|c|c|c|c|c|c|c|c|}
\hline Sujeito & Sexo & $\begin{array}{c}\text { Comprimento } \\
\text { Facial (mm) }\end{array}$ & $\begin{array}{c}\text { Comprimento } \\
\text { do lábio sup. } \\
\text { (mm) }\end{array}$ & $\begin{array}{c}\text { Gap interlabial } \\
(\mathbf{m m})\end{array}$ & $\begin{array}{c}\text { Comprimento } \\
\text { do lábio inf. } \\
\text { (mm) }\end{array}$ & $\begin{array}{l}\text { Terço inferior } \\
\text { da face }(\mathrm{mm})\end{array}$ & $\begin{array}{l}\text { Overbite } \\
\text { (mm) }\end{array}$ & $\begin{array}{l}\text { Exposição } \\
\text { de incisivo } \\
\text { (mm) }\end{array}$ & $\begin{array}{c}\text { Comprimento } \\
\text { anterior da } \\
\text { maxila (mm) }\end{array}$ & $\begin{array}{c}\text { Comprimento } \\
\text { anterior da } \\
\text { mandíbula } \\
(\mathrm{mm})\end{array}$ \\
\hline 30 & $f$ & 115,1 & 23,2 & 3,5 & 43,4 & 70,2 & 3 & 6 & 29,8 & 43,4 \\
\hline 31 & $f$ & 116 & 22,3 & 1,2 & 44,6 & 68,1 & 1,3 & 4 & 26,3 & 43,1 \\
\hline 32 & $f$ & 123,1 & 22,4 & 1,2 & 46,7 & 70,4 & 4,6 & 4 & 26,4 & 48,6 \\
\hline 33 & $f$ & 127,1 & 19,3 & 0,9 & 48,5 & 68,8 & 2,7 & 2,7 & 22,1 & 49,4 \\
\hline 34 & $f$ & 128,1 & 23 & 1,6 & 52,2 & 76,8 & 1 & 2,6 & 25,6 & 52,2 \\
\hline 35 & $f$ & 119,9 & 21,9 & 3,5 & 47 & 72,4 & 2,5 & 4,8 & 26,7 & 48,1 \\
\hline 36 & $f$ & 130,6 & 28,8 & 1,8 & 50,7 & 81,3 & 1,2 & 2 & 30,8 & 51,8 \\
\hline 37 & $f$ & 134,7 & 23,4 & 2,3 & 52,5 & 78,1 & 2,1 & 4,9 & 28,2 & 52 \\
\hline 38 & $f$ & 121,7 & 18,7 & 2,2 & 50,2 & 71,1 & 3,6 & 5,8 & 24,5 & 50,2 \\
\hline 39 & $f$ & 139,6 & 27,6 & 1,1 & 54,7 & 83,4 & 2,7 & 2,8 & 30,5 & 55,6 \\
\hline
\end{tabular}


APÊNDICE 4 - Medidas de projeção em relação à LVV dos feodermas brasileiros

\begin{tabular}{|c|c|c|c|c|c|c|c|c|}
\hline Sujeito & Sexo & $\begin{array}{c}\text { Glabela tegumentar } \\
(\mathrm{mm})\end{array}$ & $\begin{array}{c}\text { Infra-orbitário } \\
\text { tegumentar (mm) }\end{array}$ & $\begin{array}{c}\text { Malar } \\
\text { tegumentar }\end{array}$ & $\begin{array}{l}\text { Ponto subpupilar } \\
\text { tegumentar (mm) }\end{array}$ & $\begin{array}{c}\text { Base nasal } \\
(\mathrm{mm})\end{array}$ & $\begin{array}{c}\text { Pronasal } \\
(\mathrm{mm})\end{array}$ & $\begin{array}{c}\text { Subnasal } \\
(\mathrm{mm})\end{array}$ \\
\hline 1 & $\mathrm{~m}$ & $-8,4$ & $-19,8$ & $-27,1$ & $-13,8$ & $-11,5$ & 16,1 & 0 \\
\hline 2 & $\mathrm{~m}$ & $-8,5$ & $-23,2$ & $-30,5$ & $-16,7$ & $-13,5$ & 13,2 & 0 \\
\hline 3 & $\mathrm{~m}$ & $-8,5$ & $-23,1$ & $-23,1$ & $-33,6$ & $-18,8$ & 16,1 & 0 \\
\hline 4 & $\mathrm{~m}$ & $-8,5$ & -22 & $-30,4$ & $-14,1$ & -12 & 21,3 & 0 \\
\hline 5 & $\mathrm{~m}$ & $-8,4$ & $-22,6$ & $-29,7$ & $-19,2$ & $-14,2$ & 14,2 & 0 \\
\hline 6 & $\mathrm{~m}$ & $-8,5$ & $-24,9$ & $-39,1$ & $-20,2$ & $-11,9$ & 15,1 & 0 \\
\hline 7 & $\mathrm{~m}$ & $-8,5$ & $-24,1$ & $-24,1$ & $-18,9$ & $-14,2$ & 17,3 & 0 \\
\hline 8 & $\mathrm{~m}$ & $-8,5$ & $-26,3$ & $-34,8$ & $-20,2$ & $-16,3$ & 19 & 0 \\
\hline 9 & $\mathrm{~m}$ & $-8,5$ & $-21,3$ & $-29,5$ & $-16,9$ & $-14,1$ & 15,6 & 0 \\
\hline 10 & $\mathrm{~m}$ & $-8,5$ & -25 & $-27,2$ & $-20,5$ & $-16,4$ & 16,5 & 0 \\
\hline 11 & $\mathrm{~m}$ & $-8,5$ & -27 & $-28,4$ & $-20,3$ & $-13,4$ & 16 & 0 \\
\hline 12 & $\mathrm{~m}$ & $-8,5$ & $-24,2$ & $-26,8$ & $-18,8$ & $-13,5$ & 16,6 & 0 \\
\hline 13 & $\mathrm{~m}$ & $-8,5$ & $-27,1$ & $-38,6$ & $-24,4$ & $-16,6$ & 15,3 & 0 \\
\hline 14 & $\mathrm{~m}$ & $-8,5$ & $-20,6$ & $-23,2$ & $-13,5$ & $-8,1$ & 14,5 & 0 \\
\hline 15 & $\mathrm{~m}$ & $-8,5$ & $-21,8$ & $-17,9$ & $-23,9$ & $-14,6$ & 19 & 0 \\
\hline 16 & $\mathrm{~m}$ & $-8,5$ & $-25,3$ & $-28,4$ & $-18,2$ & $-10,4$ & 18,8 & 0 \\
\hline 17 & $\mathrm{~m}$ & $-8,4$ & $-19,1$ & $-27,2$ & $-14,9$ & $-10,3$ & 17,2 & 0 \\
\hline 18 & $\mathrm{~m}$ & $-8,5$ & $-22,5$ & $-31,9$ & $-20,9$ & $-13,1$ & 16,9 & 0 \\
\hline 19 & $\mathrm{~m}$ & $-8,5$ & $-20,6$ & $-21,9$ & $-14,5$ & $-12,3$ & 16,7 & 0 \\
\hline 20 & $f$ & $-8,4$ & -24 & $-34,5$ & $-20,4$ & $-12,1$ & 16,7 & 0 \\
\hline 21 & $f$ & $-8,5$ & $-20,1$ & $-25,9$ & $-15,7$ & -10 & 13 & 0 \\
\hline 22 & $f$ & $-8,5$ & -22 & $-22,4$ & $-14,2$ & $-8,6$ & 14,7 & 0 \\
\hline 23 & f & $-8,5$ & -23 & $-33,3$ & $-18,2$ & $-13,7$ & 14,8 & 0 \\
\hline 24 & $f$ & $-6,4$ & $-15,8$ & $-21,2$ & -12 & $-6,9$ & 11,4 & 0 \\
\hline 25 & $f$ & $-8,5$ & $-20,1$ & $-24,1$ & $-11,9$ & $-9,6$ & 13,4 & 0 \\
\hline 26 & $f$ & $-8,5$ & $-21,6$ & $-34,3$ & $-20,2$ & $-15,2$ & 14,8 & 0 \\
\hline 27 & $f$ & $-8,5$ & $-23,6$ & $-27,6$ & $-13,3$ & $-8,8$ & 11,8 & 0 \\
\hline 28 & $f$ & $-8,5$ & $-20,8$ & $-24,6$ & $-17,1$ & -13 & 13,9 & 0 \\
\hline 29 & $f$ & $-8,5$ & $-19,2$ & $-26,6$ & $-13,9$ & $-11,7$ & 14 & 0 \\
\hline
\end{tabular}


APÊNDICE 4 - (Cont.)

\begin{tabular}{|c|c|c|c|c|c|c|c|c|}
\hline Sujeito & Sexo & $\begin{array}{c}\text { Glabela tegumentar } \\
(\mathrm{mm})\end{array}$ & $\begin{array}{c}\text { Infra-orbitário } \\
\text { tegumentar }(\mathrm{mm})\end{array}$ & $\begin{array}{c}\text { Malar } \\
\text { tegumentar }\end{array}$ & $\begin{array}{l}\text { Ponto subpupilar } \\
\text { tegumentar (mm) }\end{array}$ & $\begin{array}{c}\text { Base nasal } \\
(\mathrm{mm})\end{array}$ & $\begin{array}{c}\text { Pronasal } \\
(\mathrm{mm})\end{array}$ & $\begin{array}{c}\text { Subnasal } \\
(\mathrm{mm})\end{array}$ \\
\hline 30 & $f$ & 0 & $-14,5$ & -23 & $-12,3$ & -11 & 16,2 & 0 \\
\hline 31 & $f$ & $-8,4$ & $-21,1$ & $-26,6$ & -19 & $-14,9$ & 13,8 & 0 \\
\hline 32 & $f$ & $-8,5$ & $-21,5$ & -28 & $-16,3$ & $-10,8$ & 17 & 0 \\
\hline 33 & $f$ & $-8,5$ & $-20,5$ & $-23,7$ & $-13,2$ & $-5,9$ & 16,2 & 0 \\
\hline 34 & $f$ & $-8,5$ & -21 & $-24,2$ & $-13,1$ & $-10,5$ & 14,3 & 0 \\
\hline 35 & $f$ & $-8,5$ & $-19,3$ & -24 & $-13,7$ & $-10,3$ & 13,1 & 0 \\
\hline 36 & $f$ & $-8,5$ & $-16,8$ & $-23,2$ & $-13,4$ & $-7,8$ & 15,9 & 0 \\
\hline 37 & $f$ & $-8,3$ & $-21,7$ & $-28,8$ & $-18,9$ & $-14,1$ & 16,8 & 0 \\
\hline 38 & $f$ & $-8,5$ & $-18,7$ & $-23,3$ & $-14,5$ & $-8,7$ & 12,9 & 0 \\
\hline 39 & $f$ & $-8,5$ & $-22,9$ & $-27,3$ & $-16,8$ & $-11,9$ & 17,2 & 0 \\
\hline
\end{tabular}


APÊNDICE 5 - Medidas de projeção em relação à LVV dos feodermas brasileiros

\begin{tabular}{|c|c|c|c|c|c|c|c|c|}
\hline Sujeito & Sexo & $\begin{array}{c}\text { Ponto A } \\
\text { tegumentar } \\
(\mathrm{mm})\end{array}$ & $\begin{array}{l}\text { Lábio superior } \\
\text { (mm) }\end{array}$ & $\begin{array}{c}\text { Borda do } \\
\text { incisivo sup. } \\
\text { (mm) }\end{array}$ & $\begin{array}{c}\text { Borda do } \\
\text { incisivo inf. } \\
(\mathrm{mm})\end{array}$ & $\begin{array}{l}\text { Lábio inferior } \\
\text { (mm) }\end{array}$ & $\begin{array}{c}\text { Ponto B } \\
\text { tegumentar } \\
\text { (mm) }\end{array}$ & $\begin{array}{c}\text { Pogônio } \\
\text { tegumentar } \\
(\mathrm{mm})\end{array}$ \\
\hline 1 & $m$ & 0,3 & 6,3 & $-8,1$ & $-12,4$ & 3,9 & $-4,7$ & 1,3 \\
\hline 2 & $\mathrm{~m}$ & $-1,3$ & 2,3 & $-14,2$ & $-19,8$ & $-3,3$ & $-15,4$ & $-13,1$ \\
\hline 3 & $\mathrm{~m}$ & 0,1 & 5,7 & -9 & $-12,5$ & 4,1 & $-5,1$ & $-4,6$ \\
\hline 4 & $\mathrm{~m}$ & $-0,4$ & 5 & $-9,6$ & $-12,4$ & 5,4 & $-0,3$ & 4,6 \\
\hline 5 & $\mathrm{~m}$ & 0,8 & 9,2 & -8 & $-10,4$ & 3,4 & $-7,2$ & $-14,2$ \\
\hline 6 & $\mathrm{~m}$ & $-0,4$ & 4 & $-10,6$ & $-16,6$ & $-0,6$ & $-10,3$ & $-8,3$ \\
\hline 7 & $\mathrm{~m}$ & 1,8 & 9,9 & $-7,9$ & $-11,3$ & 6,7 & -2 & 0,2 \\
\hline 8 & $\mathrm{~m}$ & $-0,4$ & 1,5 & $-13,7$ & $-17,7$ & $-4,2$ & $-13,3$ & $-9,8$ \\
\hline 9 & $\mathrm{~m}$ & 3,4 & 9,2 & $-11,6$ & $-15,6$ & 3,5 & $-5,4$ & $-4,1$ \\
\hline 10 & $\mathrm{~m}$ & 0,4 & 3,1 & $-10,9$ & $-15,7$ & 2,3 & $-8,9$ & $-8,7$ \\
\hline 11 & $\mathrm{~m}$ & 0 & 4,8 & $-7,7$ & $-10,4$ & 3,3 & $-8,5$ & -6 \\
\hline 12 & $\mathrm{~m}$ & $-2,2$ & 3,2 & -15 & $-19,2$ & $-4,9$ & $-15,2$ & $-14,2$ \\
\hline 13 & $\mathrm{~m}$ & $-2,2$ & 3,2 & $-12,5$ & $-16,9$ & -3 & $-12,1$ & $-8,3$ \\
\hline 14 & $\mathrm{~m}$ & $-0,4$ & 5,9 & $-10,6$ & $-14,3$ & 5,4 & $-2,4$ & 2,8 \\
\hline 15 & $\mathrm{~m}$ & 0,7 & 5,5 & $-10,1$ & $-14,2$ & $-0,3$ & $-11,7$ & $-14,8$ \\
\hline 16 & $\mathrm{~m}$ & 1,8 & 6,7 & -13 & $-17,4$ & -1 & $-12,2$ & $-8,8$ \\
\hline 17 & $\mathrm{~m}$ & 1,5 & 4,2 & $-9,4$ & $-12,3$ & 1,3 & $-9,8$ & $-7,1$ \\
\hline 18 & $\mathrm{~m}$ & 0,2 & 7,5 & $-9,1$ & $-12,9$ & 5,8 & $-9,2$ & $-9,8$ \\
\hline 19 & $\mathrm{~m}$ & $-0,1$ & 4 & $-8,6$ & $-13,2$ & 4,6 & $-1,3$ & $-1,6$ \\
\hline 20 & $f$ & $-3,2$ & 1,1 & $-11,1$ & $-15,3$ & $-3,8$ & $-12,5$ & $-14,5$ \\
\hline 21 & $f$ & 1,1 & 5,8 & $-8,1$ & $-11,9$ & 2,4 & $-8,7$ & $-10,3$ \\
\hline 22 & $f$ & 1,6 & 6,5 & -7 & -10 & 4,4 & $-1,3$ & 4,1 \\
\hline 23 & $f$ & 2,2 & 6,8 & $-10,2$ & $-13,4$ & 1,5 & $-6,2$ & $-4,4$ \\
\hline 24 & $f$ & 0,1 & 3,7 & $-5,4$ & $-7,9$ & $-0,1$ & $-5,5$ & $-4,8$ \\
\hline 25 & $f$ & $-0,4$ & 9,5 & $-9,4$ & -12 & 4 & $-8,1$ & $-6,2$ \\
\hline 26 & $f$ & 0,1 & 5,3 & $-10,5$ & $-13,8$ & $-1,5$ & $-13,7$ & $-15,3$ \\
\hline 27 & $f$ & $-0,1$ & 6,5 & $-3,4$ & $-6,3$ & 7,5 & 0,1 & $-0,5$ \\
\hline 28 & $f$ & $-0,4$ & 3,2 & $-10,2$ & $-14,3$ & $-0,3$ & $-7,2$ & $-6,9$ \\
\hline 29 & $f$ & 0,9 & 5,6 & $-8,8$ & $-12,3$ & 1,1 & $-6,5$ & $-4,7$ \\
\hline
\end{tabular}


APÊNDICE 5 - (Cont.)

\begin{tabular}{|c|c|c|c|c|c|c|c|c|}
\hline Sujeito & Sexo & $\begin{array}{c}\text { Ponto A } \\
\text { tegumentar } \\
(\mathrm{mm})\end{array}$ & $\begin{array}{c}\text { Lábio superior } \\
\text { (mm) }\end{array}$ & $\begin{array}{c}\text { Borda do } \\
\text { incisivo sup. } \\
(\mathrm{mm})\end{array}$ & $\begin{array}{c}\text { Borda do } \\
\text { incisivo inf. } \\
(\mathrm{mm})\end{array}$ & $\begin{array}{c}\text { Lábio inferior } \\
(\mathrm{mm})\end{array}$ & $\begin{array}{c}\text { Ponto B } \\
\text { tegumentar } \\
(\mathrm{mm})\end{array}$ & $\begin{array}{c}\text { Pogônio } \\
\text { tegumentar } \\
(\mathrm{mm})\end{array}$ \\
\hline 30 & $f$ & $-3,8$ & $-0,1$ & $-15,7$ & $-18,1$ & $-4,4$ & $-13,2$ & $-16,8$ \\
\hline 31 & $f$ & $-0,7$ & 1,7 & $-10,2$ & $-13,2$ & 0,3 & 6,8 & $-10,4$ \\
\hline 32 & $f$ & 0,3 & 5,8 & $-13,6$ & -17 & $-2,2$ & $-2,2$ & $-10,9$ \\
\hline 33 & $f$ & 6 & 9,5 & $-2,7$ & $-6,3$ & 3,6 & $-2,6$ & $-1,4$ \\
\hline 34 & $f$ & 1,7 & 8 & $-9,9$ & $-12,3$ & 5,8 & $-5,4$ & $-1,8$ \\
\hline 35 & $f$ & 2,2 & 7,6 & -8 & $-11,3$ & 5,4 & $-4,4$ & $-2,1$ \\
\hline 36 & $f$ & 2,8 & 8,8 & $-2,6$ & $-5,6$ & 9,7 & $-0,5$ & $-1,1$ \\
\hline 37 & $f$ & $-0,6$ & 4,5 & -17 & $-20,6$ & $-2,3$ & $-12,5$ & $-11,6$ \\
\hline 38 & $f$ & $-1,6$ & 3 & $-13,7$ & $-17,9$ & 2,5 & $-8,5$ & $-8,9$ \\
\hline 39 & $f$ & 3,2 & 9,8 & $-10,7$ & $-12,8$ & 9,1 & $-6,5$ & $-8,2$ \\
\hline
\end{tabular}


